\title{
Investigations into the Early Life-history of Naturally Produced Spring Chinook Salmon and Summer Steelhead in the Grande Ronde River Basin
}

\section{Annual Report}

\section{1}

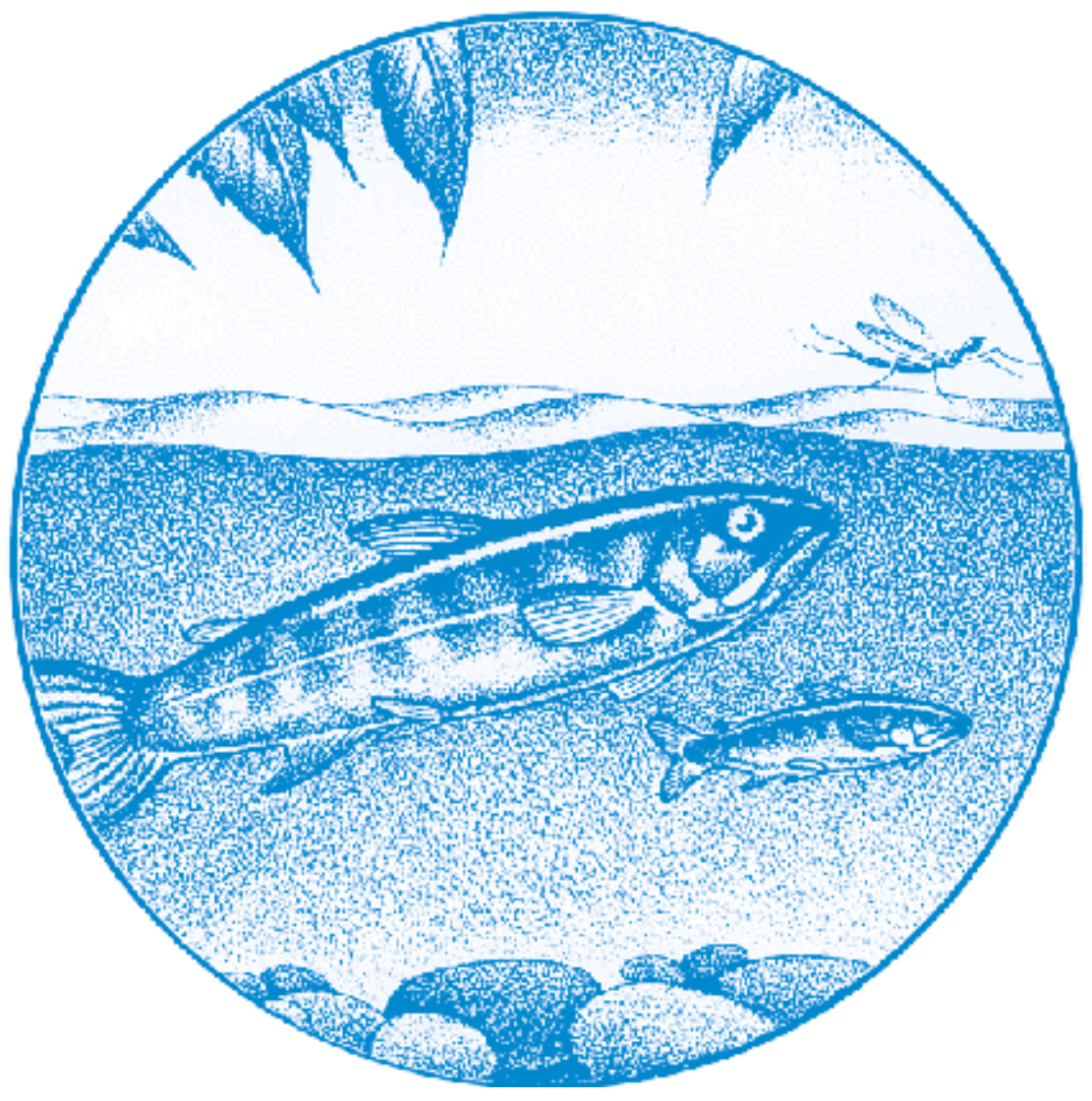

DOE/BP-00004119-1

June 2003 
This Document should be cited as follows:

Reischauer, Alyssa, Frederick Monzyk, Erick Van Dyke, Brian Jonasson, Richard

Carmichael, "Investigations into the Early Life-history of Naturally Produced Spring

Chinook Salmon and Summer Steelhead in the Grande Ronde River Basin", Project No.

1992-02604, 126 electronic pages, (BPA Report DOE/BP-00004119-1)

\section{Bonneville Power Administration \\ P.O. Box 3621 \\ Portland, Oregon 97208}

This report was funded by the Bonneville Power Administration (BPA), U.S. Department of Energy, as part of BPA's program to protect, mitigate, and enhance fish and wildlife affected by the development and operation of hydroelectric facilities on the Columbia River and its tributaries. The views in this report are the author's and do not necessarily represent the views of BPA. 


\title{
INVESTIGATIONS INTO THE EARLY LIFE HISTORY OF NATURALLY PRODUCED SPRING CHINOOK SALMON AND SUMMER STEELHEAD IN THE GRANDE RONDE RIVER BASIN
}

\author{
ANNUAL REPORT 2001 \\ Project Period: 1 December 2000 to 30 November 2001
}

\author{
Prepared by: \\ Alyssa G. Reischauer \\ Frederick R. Monzyk \\ Erick S. Van Dyke \\ Brian C. Jonasson \\ Richard W. Carmichael
}

Oregon Department of Fish and Wildlife

La Grande, OR

Prepared for:

U. S. Department of Energy

Bonneville Power Administration

Environment, Fish and Wildlife

P.O. Box 3621

Portland, OR 97208-3621

Project Number 1992-026-04

Contract Number 00000225 


\begin{abstract}
We determined migration timing and abundance of juvenile spring chinook salmon Oncorhynchus tshawytscha and juvenile steelhead/rainbow trout Oncorhynchus mykiss using rotary screw traps on four streams in the Grande Ronde River basin during the 2001 migratory year (MY 2001) from 1 July 2000 through 30 June 2001. Based on migration timing and abundance, two distinct life-history strategies of juvenile spring chinook and $O$. mykiss could be distinguished. An 'early' migrant group left upper rearing areas from 1 July 2000 through 29 January 2001 with a peak in the fall. A 'late' migrant group descended from upper rearing areas from 30 January 2001 through 30 June 2001 with a peak in the spring. The migrant population of juvenile spring chinook salmon in the upper Grande Ronde River in MY 2001 was very low in comparison to previous migratory years. We estimated 51 juvenile spring chinook migrated out of upper rearing areas with approximately $12 \%$ of the migrant population leaving as early migrants to overwinter downstream. In the same migratory year, we estimated 16,067 O. mykiss migrants left upper rearing areas with approximately $4 \%$ of these fish descending the upper Grande Ronde River as early migrants. At the Catherine Creek trap, we estimated 21,937 juvenile spring chinook migrants in MY 2001. Of these migrants, 87\% left upper rearing areas early to overwinter downstream. We also estimated 20,586 O. mykiss migrants in Catherine Creek with 44\% leaving upper rearing areas early to overwinter downstream. At the Lostine River trap, we estimated 13,610 juvenile spring chinook migrated out of upper rearing areas with approximately $77 \%$ migrating early. We estimated 16,690 O. mykiss migrated out of the Lostine River with approximately $46 \%$ descending the river as early migrants. At the Minam River trap, we estimated 28,209 juvenile spring chinook migrated out of the river with $36 \%$ migrating early. During the same period, we estimated 28,113 O. mykiss with approximately $14 \%$ of these fish leaving as early migrants.
\end{abstract}

Juvenile spring chinook salmon PIT-tagged at trap sites in the fall and in upper rearing areas during winter were used to compare migration timing and survival to Lower Granite Dam of the early and late migrant groups. Juvenile spring chinook tagged on the upper Grande Ronde River were detected at Lower Granite Dam from 4 May to 20 May 2001, with a median passage date of 17 May. Too few fish were collected and tagged to conduct detection rate and survival comparisons between migrant groups. PIT-tagged salmon from Catherine Creek trap were detected at Lower Granite Dam from 27 April to 13 July 2001. Early migrants were detected significantly earlier (median $=10$ May) than late migrants (median $=1$ June). Also, early migrants from Catherine Creek were detected at a significantly higher rate than fish tagged in upper rearing areas in the winter, suggesting better survival for fish that migrated out of upper rearing areas in the fall. Juvenile spring chinook salmon from the Lostine River were detected at Lower Granite Dam from 2 April through 4 July 2001. Early migrants were detected significantly earlier (median $=27$ April) than late migrants (median $=14$ May). However, there was no difference in detection rates between early and late migrants. Survival probabilities showed similar patterns as dam detection rates. Juvenile spring chinook salmon from the Minam River were detected at Lower Granite Dam from 8 April through 18 August 2001. Early migrants were detected significantly earlier (median $=28$ April) than late migrants (median $=14$ May). Late migrants from the Minam River were tagged at the trap in the spring.

Spring chinook salmon parr PIT-tagged in summer 2000 on Catherine Creek and the 
Imnaha, Lostine, and Minam rivers were detected at Lower Granite Dam over an $87 \mathrm{~d}$ period from 8 April to 3 July 2001. The migratory period of individual populations ranged from $51 \mathrm{~d}$ (Imnaha River) to $67 \mathrm{~d}$ (Catherine Creek) in length. Median dates of migration ranged from 30 April (Imnaha River) to 17 May (Catherine Creek). Detection rates differed between populations with Catherine Creek spring chinook salmon detected at the lowest rate (8.2\%). Imnaha, Lostine, and Minam detection rates were not significantly different from each other. A similar pattern was seen for survival probabilities.

Using mark-and-recapture and scale-aging techniques, we determined the population size and age-structure of spring chinook salmon parr in Catherine Creek and the Lostine River during the summer of 2001. In Catherine Creek, we estimated that 986 mature age-1 parr (precocious males) and 15,032 immature age-0 parr were present during August 2001. We estimated there were 7.5 mature male parr for every anadromous female spawner in Catherine Creek in 2001. We estimated 33,086 immature, age-0 parr inhabited the Lostine River in August 2001. Mature male parr were observed, but not enough were marked to calculate a population estimate.

We used mark-and-recapture and scale-aging techniques to determine population size and age-structure of $O$. mykiss in the mainstem Catherine Creek and its tributary the North Fork Catherine Creek during the summer of 2001. We estimated that 25,736 O. mykiss inhabited the mainstem Catherine Creek and 10,338 O. mykiss inhabited the North Fork. Scale analysis showed that $O$. mykiss ranged from age- 0 to age- 3 at both localities.

We PIT-tagged juvenile O. mykiss at screw traps on Catherine Creek, and the upper Grande Ronde, Lostine, and Minam rivers during the fall of 2000 (early migrants) and spring of 2001 (late migrants). PIT-tagged fish were detected at Lower Granite Dam in 2001 between 12 April and 18 August. Early migrants from Catherine Creek reached Lower Granite Dam significantly earlier (median $=6$ May) than late migrants (median $=14$ May). Median arrival date for early migrants from the upper Grande Ronde River was 7 May; and for late migrants was 5 May. In the Lostine River, there was no difference in arrival dates of early migrants $($ median $=12$ May) and late migrants (median $=14$ May). Similarly, there was no difference in arrival dates of early migrants (median $=9$ May) and late migrants (median $=7$ May) from the Minam River.

The $O$. mykiss migrants collected at traps in MY 2001 ranged from 0 to 3 years of age which was consistent with the summer rearing populations. Most early migrants collected at the trap were age- 1 with few age- 0 or age- 2 migrants present. These age- 1 migrants would presumably resume their seaward migration the following spring as age- 2 smolts. During the late migration period, the proportion of age- 2 migrants was greater but never reached over $50 \%$ of the total late migrant population. Of the fish with known ages that were PIT-tagged at the traps in MY 2001 and subsequently detected at Snake/Columbia River dams, most (91\%) reached the dams as age- 2 smolts while four (9\%) were age-3. No age-1 smolts were detected in MY 2001. 


\section{CONTENTS}

$\underline{\text { Page }}$

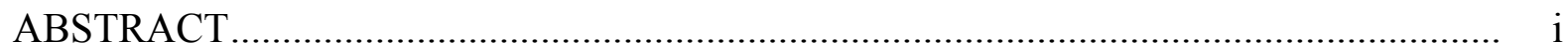

EXECUTIVE SUMMARY ................................................................................ 1

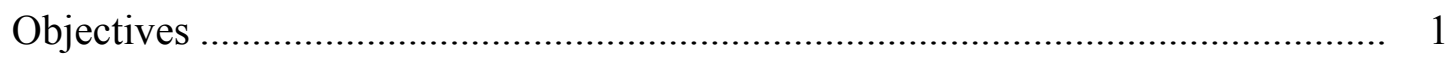

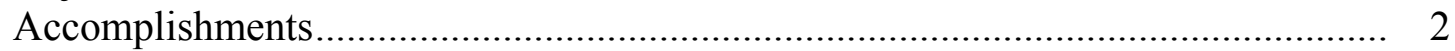

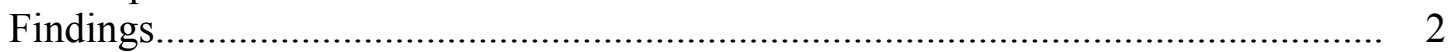

Spring Chinook Salmon ..................................................................... 3

Summer Steelhead ...................................................................... 4

Management Implications and Recommendations ........................................ 5

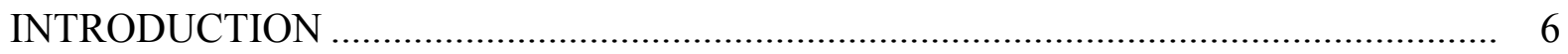

GOALS AND OBJECTIVES ......................................................................... 8

SPRING CHINOOK SALMON INVESTIGATIONS ............................................. 9

Methods................................................................................................. 9

Egg-to-Parr Survival, Parr Abundance, and Age

Composition in Summer ................................................................ 9

In-Basin Migration Timing and Abundance ........................................... 11

Migration Timing and Survival to Lower Granite Dam ............................ 14

Results and Discussion ........................................................................... 17

Egg-to-Parr Survival, Parr Abundance, and Age

Composition in Summer ................................................................. 17

In-Basin Migration Timing and Abundance ............................................ 18

Migration Timing and Survival to Lower Granite Dam ........................... 21

Alternate Life History Strategies ...................................................... 24

SUMMER STEELHEAD INVESTIGATIONS ........................................................ 25

Methods...................................................................................................... 25

Characterization of the O. mykiss Population in Catherine Creek and

Tributaries During the Summer ........................................................... 25

In-Basin Migration Timing and Abundance ......................................... 28

Migration Timing to Lower Granite Dam ................................................ 29

Detections at Snake and Columbia River Dams ...................................... 29

Length and Age of Migrants ........................................................... 30 


\section{CONTENTS (continued)}

$\underline{\text { Page }}$

Results and Discussion ................................................................................. 30

Characterization of the O. mykiss Population in Catherine Creek and Tributaries During Summer ............................................................... 30

In-Basin Migration Timing and Abundance ......................................... 31

Migration Timing to Lower Granite Dam .......................................... 33

Detections at Snake and Columbia River Dams ...................................... 35

Length and Age of Migrants ............................................................. 35

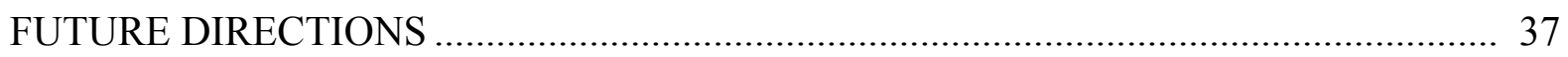

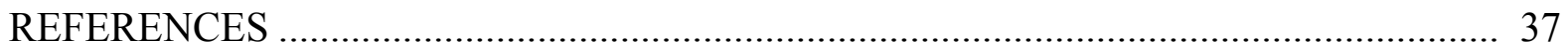

APPENDIX A. A Compilation of Spring Chinook Salmon Data ................................... 85

APPENDIX B. A Compilation of Oncorhynchus mykiss Data ........................................ 103 


\section{TABLES}

Number

$\underline{\text { Page }}$

1. Dates of tagging and number of spring chinook salmon parr PIT-tagged

on various northeast Oregon streams during the summers of 2000 and 2001

2. Results from spring chinook salmon mark-and-recapture experiments conducted in Catherine Creek and the Lostine River in August 2001

3. Percent of spring chinook salmon parr population and parr density in Catherine Creek by reach in August 2001

4. Age composition of immature and mature spring chinook salmon parr sampled in Catherine Creek and the Lostine, Minam, and Imnaha rivers in summer 2001

5. Estimated abundance of age- 0 spring chinook salmon parr during the summer, and the corresponding egg-to-parr survival of spring chinook salmon in Catherine Creek and the Lostine River for the 1997-2000 brood years

6. Population estimates, median emigration dates, and percentage of juvenile spring chinook salmon population moving as late migrants past traps sites, 1994 to 2001 migratory years

7. Catch of juvenile spring chinook salmon at five trap locations in the Grande Ronde River basin during the 2001 migratory year

8. Fork lengths of juvenile spring chinook salmon collected from the upper Grande Ronde River during MY 2001

9. Weights of juvenile spring chinook salmon collected from the upper Grande Ronde River during MY 2001

10. Fork lengths of juvenile spring chinook salmon collected from Catherine Creek during MY 2001

11. Weights of juvenile spring chinook salmon collected from Catherine Creek during MY 2001

12. Fork lengths of juvenile spring chinook salmon collected from the Lostine River during MY 2001

13. Weights of juvenile spring chinook salmon collected from the Lostine River during MY 2001 


\section{TABLES (continued)}

Number

$\underline{\text { Page }}$

14. Fork lengths of juvenile spring chinook salmon collected from the Minam River during MY 2001

15. Weights of juvenile spring chinook salmon collected from the Minam River during MY 2001

16. Comparison of spring chinook salmon parr survival indices based on first-time dam detection rates of PIT-tagged parr and Cormack-Jolly-Seber estimates of survival probabilities, listed by stream and tag group for the 2001 migratory year

17. Detection rates and CJS survival probabilities to Lower Granite Dam for spring chinook salmon parr tagged in summer 2000 and detected at Columbia and Snake River dams in 2001

18. Sampling reaches on North Fork Catherine Creek for estimating the population of $O$. mykiss in summer 2001

19. Sampling methods specific to reaches 2 and 3 on North Fork Catherine

Creek for estimating the population of $O$. mykiss in summer 2001

20. Sampling methods specific to reaches 4 and 5 on North Fork Catherine Creek for estimating the population of $O$. mykiss in summer 2001

21. Population estimates of $O$. mykiss in the Catherine Creek watershed in summer 2001

22. Growth rates $(\mathrm{mm} / \mathrm{d})$ of $O$. mykiss tagged 27 June - 31 July 2000 upstream of the Catherine Creek screw trap and recaptured at the screw trap in fall 2000 and spring 2001, and upstream in summer 2001

23. Catch of juvenile O. mykiss at five trap locations in the Grande Ronde River basin during the 2001 migratory year.....

24. Population estimates, median emigration dates, and percentage of O. mykiss population moving as late migrants past traps sites, 1997 to 2001 migratory years

25. Travel time to Lower Granite Dam of wild O. mykiss PIT-tagged at upstream screw traps in spring of 2001 and arriving at Lower Granite Dam in 2001 


\section{TABLES (continued)}

Number

$\underline{\text { Page }}$

26. Detections at Snake and Columbia River dams in 2001 of wild O. mykiss juveniles PIT-tagged at screw traps on Catherine Creek and the upper

Grande Ronde, Lostine, and Minam rivers during fall 1999 and 2000

27. Detections at Snake and Columbia River dams in 2001 of wild O. mykiss juveniles PIT-tagged at screw traps on Catherine Creek and the Grande Ronde, Lostine, and Minam rivers during spring 2000 and 2001

28. Detection rates at Snake and Columbia River dams of $O$. mykiss PIT-tagged on Catherine Creek and its tributaries during summer 2000

29. Length at age of $O$. mykiss collected from the upper Grande Ronde River, Catherine Creek, the Lostine River, and the Minam River during the early and late migration periods 


\section{FIGURES}

Number

$\underline{\text { Page }}$

1. Locations of fish traps in the Grande Ronde River basin during the study period.

2. Estimated migration timing and abundance of juvenile spring chinook salmon migrants captured by rotary screw traps during the 2001 migratory year.....

3. Length frequency distribution of juvenile spring chinook salmon migrants captured at the upper Grande Ronde River trap by migration period, during the 2001 migratory year.....

4. Length frequency distribution of juvenile spring chinook salmon migrants captured at the Catherine Creek trap by migration period, during the 2001 migratory year

5. Length frequency distribution of juvenile spring chinook salmon migrants captured at the Grande Ronde Valley trap by migration period, during the 2001 migratory year

6. Length frequency distribution of juvenile spring chinook salmon migrants captured at the Lostine River trap by migration period, during the 2001 migratory year

7. Length frequency distribution of juvenile spring chinook salmon migrants captured at the Minam River trap by migration period, during the 2001 migratory year

8. Weekly mean fork lengths with standard error for spring chinook salmon captured in rotary screw traps in the Grande Ronde and Wallowa basins during migratory year 2001

9. Dates of detection in 2001 at Lower Granite Dam for the fall, winter, and spring tag groups of juvenile spring chinook salmon PIT-tagged on Catherine Creek, expressed as a percentage of the total detected for each group

10. Dates of detection in 2001 at Lower Granite Dam for the fall, winter, and spring tag groups of juvenile spring chinook salmon PIT-tagged on the Lostine River, expressed as a percentage of the total detected for each group

11. Dates of detection in 2001 at Lower Granite Dam for fall and spring tag groups of juvenile spring chinook salmon PIT-tagged on the Minam River, expressed as a percentage of the total detected for each group 


\section{FIGURES (continued)}

$\underline{\text { Number }}$

$\underline{\text { Page }}$

12. Dates of detection in 2001 at Lower Granite Dam for the spring tag group of juvenile spring chinook salmon PIT-tagged on the upper Grande Ronde River, expressed as a percentage of the total detected....

13. Dates of detection in 2001 at Lower Granite Dam of spring chinook salmon PIT-tagged as parr on Catherine Creek and the Imnaha, Lostine, and Minam rivers during the summer of 2000 , summarized by week and expressed as a percentage of the total detected for each group

14. Median and first and last detection dates at Lower Granite Dam for wild chinook smolts tagged as parr during the summer in Catherine Creek, Lostine, Minam, and the Imnaha rivers, for migratory years 1993-2001

15. Dam detection rates and $95 \%$ CI for spring chinook salmon parr PIT-tagged during the summer in Catherine Creek and the Lostine, Minam, and Imnaha rivers, for migratory years 1993-2001

16. Age composition of the O. mykiss populations in Catherine Creek and North Fork Catherine Creek during early summer of 2001

17. Fork lengths of $O$. mykiss in Catherine Creek and North Fork Catherine Creek measured during the summer of 2001

18. Estimated abundance and migration timing of $O$. mykiss migrants captured by rotary screw traps, during migratory year 2001

19. Migration timing by tag group of $O$. mykiss PIT-tagged on the upper Grande Ronde River and subsequently detected at Lower Granite Dam during the 2001 migratory year.

20. Migration timing by tag group of $O$. mykiss PIT-tagged on Catherine Creek and subsequently detected at Lower Granite Dam during migratory year 2001

21. Dates of detection in 2001 at Lower Granite Dam of O. mykiss PIT-tagged as parr on Catherine Creek, North Fork Catherine Creek, and South Fork Catherine Creek during the summer of 2000

22. Migration timing by tag group of $O$. mykiss PIT-tagged on the Lostine River and subsequently detected at Lower Granite Dam during the 2001 migratory year 


\section{FIGURES (continued)}

Number

$\underline{\text { Page }}$

23. Migration timing by tag group of $O$. mykiss PIT-tagged on the Minam River and subsequently detected at Lower Granite Dam during the 2001 migratory year

24. Fork lengths of all O. mykiss PIT-tagged at screw traps on Catherine Creek and the upper Grande Ronde, Lostine, and Minam rivers in the fall of 2000 and detected at Snake River or Columbia River dams in 2001 compared to lengths of all $O$. mykiss in the same tag group.

25. Fork lengths of all O. mykiss PIT-tagged at screw traps on Catherine Creek and the upper Grande Ronde, Lostine, and Minam rivers in the spring of 2001 and detected at Snake River or Columbia River dams in 2001 compared to lengths of all O. mykiss in the same tag group

26. Lengths at time of tagging of $O$. mykiss that were PIT-tagged at Catherine Creek and Lostine River screw traps during the fall of 1999, lengths of those also detected at the dams in 2001, and lengths of those also detected at the dams in 2000

27. Lengths at time of tagging of $O$. mykiss that were tagged at Catherine Creek and upper Grande Ronde and Lostine River screw traps during the spring of 2000, lengths of those also detected at the dams in 2001, and lengths of those also detected at the dams in 2000

28. Lengths of $O$. mykiss that were tagged upstream of the screw trap on Catherine Creek during the summer 2000, lengths of those migrating downstream from upper rearing habitats by late spring 2001, and lengths of those known to remain upstream through summer 2001

29. Lengths at tagging of $O$. mykiss that were tagged upstream of the screw trap on Catherine Creek during the summer of 2000 and recaptured at the screw trap in the fall of 2000 and the spring of 2001 


\section{APPENDIX TABLES}

Number

$\underline{\text { Page }}$

A-1. Ages of immature and mature, wild spring chinook salmon parr collected in summer rearing areas of Catherine Creek, and the Lostine, Minam, and Imnaha rivers, 1998-2001

A-2. Dates of tagging and number of spring chinook salmon parr PIT-tagged on various northeast Oregon streams, 1998-2001

A-3. Spring chinook salmon parr mark-recapture population estimates on Catherine Creek and the Lostine River during summer, 1998-2001.

A-4. Number of spring chinook salmon parr and number of parr produced per redd in Catherine Creek and the Lostine River during summer, by brood year, age, and maturity.

A-5. Proportion of immature age- 0 spring chinook salmon parr from one summer that remain in freshwater and mature by the next summer, and number of mature male parr present in relation to the number of redds counted....

A-6. Dates of detection at Lower Granite Dam of spring chinook salmon smolts PIT-tagged at screw traps as early and late migrants and during the winter

A-7. Travel time to Lower Granite Dam of juvenile spring chinook salmon PIT-tagged at upstream screw traps in the spring and arriving at Lower Granite Dam the same year

A-8. Detection rates of juvenile spring chinook salmon PIT-tagged on the upper Grande Ronde River, Catherine Creek, and the Lostine, Minam, and Imnaha rivers by tag group and dam site during the 2001 migratory year.....

A-9. PIT tag detection rates, CJS survival probabilities, and numbers of fish tagged and detected for juvenile spring chinook salmon by stream, 2000 and 2001 migratory years

A-10. Comparisons of overwinter survival of spring chinook salmon parr in rearing areas upstream and downstream on Catherine Creek and the Lostine and Grande Ronde rivers

A-11. Overwinter survival rates of spring chinook salmon parr overwintering upstream of screw traps on Catherine Creek and the Lostine and Grande Ronde rivers 


\section{APPENDIX TABLES (continued)}

Number

$\underline{\text { Page }}$

A-12. Median, first, and last migration dates to Lower Granite Dam for spring chinook salmon smolts PIT-tagged as parr during the previous summer, 1993-2001 migratory years

B-1. Population estimates of wild O. mykiss in Catherine Creek and its tributaries above the screw trap (rkm 32) during summer

B-2. Age composition of O. mykiss sampled in Catherine Creek and two tributaries in summer 2000 and 2001

B-3. Travel time to Lower Granite Dam of wild O. mykiss PIT-tagged at screw traps in spring and detected at the dam in the same migratory year....

B-4. Detections dates at Lower Granite Dam of wild O. mykiss PIT-tagged at screw traps as early and late migrants

B-5. Detections dates at Lower Granite Dam of wild O. mykiss that were PIT-tagged in the upper rearing areas of the Catherine Creek during summer 2000 and detected in 2001

B-6. Detection dates at Lower Granite Dam of wild O. mykiss PIT-tagged at screw traps during fall and spring in migratory year 2000 and detected at the dam in migratory year 2001

B-7. Detection rates at Snake and Columbia River dams of wild O. mykiss PIT-tagged at screw traps during spring and fall

B-8. Fork lengths of O. mykiss PIT-tagged at screw traps on Catherine Creek and the upper Grande Ronde, Lostine, and Minam rivers in the fall, summarized by dam detection history.....

B-9. Fork lengths of $O$. mykiss PIT-tagged at upper screw traps on Catherine Creek and the upper Grande Ronde, Lostine, and Minam rivers in the spring, summarized by dam detection history

B-10. Fork lengths of $O$. mykiss PIT-tagged upstream of the screw trap on Catherine Creek and its tributaries during summer 2000, summarized by migration history 


\section{EXECUTIVE SUMMARY}

\section{Objectives}

1. Document the in-basin migration patterns for spring chinook salmon juveniles in Catherine Creek and the upper Grande Ronde, Minam, and Lostine rivers, including the abundance of migrants, migration timing and duration.

2. Estimate and compare smolt detection rates and survival probabilities at mainstem Snake and Columbia river dams for early and late migrating spring chinook salmon from the tributary populations in Catherine Creek and the upper Grande Ronde, Lostine and Minam rivers

3. Estimate and compare smolt detection rates and survival probabilities at mainstem Columbia and Snake River dams for migrants from four local, natural populations of spring chinook salmon in the Grande Ronde River and Imnaha River basins.

4. Document the annual migration patterns for spring chinook salmon juveniles from four local, natural populations in the Grande Ronde River and Imnaha River basins: Catherine Creek, Lostine, Minam, Imnaha rivers.

5. Determine survival to parr stage for spring chinook salmon in two local, natural populations in the Grande Ronde River basin: Catherine Creek and Lostine River.

6. Investigate the significance of alternate life history strategies of spring chinook salmon in two local, natural populations in the Grande Ronde River basin: Catherine Creek and Lostine River.

7. Document patterns of movement for juvenile O. mykiss from tributary populations in Catherine Creek, the upper Grande Ronde, Lostine and the Minam rivers. Include data on migration timing, duration, and smolt abundance.

8. Estimate and compare smolt detection rates and survival probabilities to mainstem Columbia and Snake River dams for summer steelhead from four tributary populations: Catherine Creek and the upper Grande Ronde and Lostine, and Minam rivers.

9. Evaluate methods to estimate the proportion of $O$. mykiss captured during fall trapping that are migrating out of rearing areas and will undertake a smolt migration the following spring.

10. Describe the population characteristics of the juvenile O. mykiss population in Catherine Creek. 


\section{Accomplishments}

We accomplished all of our objectives in 2001.

\section{Findings}

In the Grande Ronde River basin, migration timing and abundance of juvenile spring chinook salmon and summer steelhead were determined by operating rotary screw traps in both upper and lower river reaches of the Grande Ronde River and Wallowa River valleys. Distinct early and late migration patterns were observed for both species at most trap sites with peaks occurring in the fall and spring, respectively. At the upper Grande Ronde River trap, only 19 juvenile spring chinook salmon were captured from 1 July 2000 through 30 June 2001. The catch was expanded to an estimate of 51 juvenile migrants. Approximately $12 \%$ of the migrant population left upper rearing areas in Grande Ronde River early (between 1 July 2000 and 29 January 2001) to overwinter downstream. During the same period, 2,645 juvenile O. mykiss were captured with the catch expanded to an abundance estimate of 16,067 migrants. Approximately $4 \%$ of these fish descended the upper Grande Ronde as early migrants. At the Catherine Creek trap, 7,659 juvenile spring chinook salmon were captured from 1 July 2000 through 30 June 2001 and the catch was expanded to an estimate of 21,937 migrants.

Approximately $87 \%$ of the Catherine Creek migrant spring chinook salmon population left upper rearing areas early and overwintered downstream. We also captured 4,820 juvenile $O$. mykiss at this trap and expanded this catch to an abundance estimate of 20,586 migrants. Approximately $44 \%$ of these migrants left upper rearing areas early to overwinter downstream. At the lower Grande Ronde River trap, 422 juvenile spring chinook salmon were captured as they left the Grande Ronde Valley from 4 October 2000 through 20 June 2001. The catch was expanded to an estimate of 3,376 spring chinook salmon migrants. Approximately 5\% of the spring chinook salmon migrant population left the Grande Ronde Valley as early migrants (between 04 October 2000 and 12 January 2001). We also captured 3,511 juvenile O. mykiss with a resultant abundance estimate of 46,470 migrants. Approximately $0.5 \%$ of the juveniles left the Grande Ronde Valley as early migrants. The estimates of spring chinook salmon and O. mykiss juveniles at this trap site were most likely underestimated due to numerous trap stoppages. At the Lostine River trap, 4,418 juvenile spring chinook salmon were captured from 1 July 2000 through 30 June 2001. The catch was expanded to an estimate of 13,610 migrants. Approximately $77 \%$ of the spring chinook salmon migrant population left upper rearing areas of the Lostine River early to overwinter downstream. We captured 2,556 juvenile O. mykiss during this same period. The catch was expanded to an estimate of 16,690 migrants, of which approximately $46 \%$ descended the Lostine river as early migrants to overwinter downstream. At the Minam River trap, 3,454 juvenile spring chinook salmon were captured as they migrated downstream 27 September 2000 through 18 June 2001. The catch was expanded to an estimate of 28,209 migrants with 36\% migrating early. During the same period, we caught 1,337 juvenile O. mykiss with a resultant population estimate of 28,113 . We estimated $14 \%$ of these fish left the Minam River as early migrants. 


\section{Spring Chinook Salmon}

Passive integrated transponders (PIT tags) were used to individually mark fish captured in traps and make subsequent observations at dams on the Snake and Columbia rivers. Juvenile spring chinook salmon PIT-tagged on the upper Grande Ronde River were detected at Lower Granite Dam from 4 May to 20 May 2001, with a median passage date of 17 May. Too few fish were collected to conduct detection rate and survival comparisons between migrant groups. PITtagged salmon from Catherine Creek were detected at Lower Granite Dam from 27 April to 13 July 2001. Early migrants were detected earlier (median $=10$ May) than late migrants (median = 1 June). The detection rate of juvenile spring chinook salmon that were tagged as they left upper rearing areas in fall (early migrants) and overwintered downstream (12.8\%) was significantly higher than the rate for late migrant fish tagged during winter in the upper rearing area $(6.9 \%)$ suggesting better survival for fish that migrated out of upper rearing areas in the fall. Juvenile spring chinook salmon from the Lostine River were detected at Lower Granite Dam from 2 April through 4 July 2001. Early migrants were detected earlier (median $=27$ April) than late migrants (median $=14$ May). The detection rate of fish that were tagged as they left the upper rearing area in fall and overwintered in areas downstream (32.9\%) was not significantly different from that of fish tagged during winter in upper rearing areas (27.7\%). Survival probabilities showed similar patterns as dam detection rates. Survival probabilities for early migrants from Catherine Creek $(\mathrm{s}=0.130)$ were significantly higher than survival probabilities for fish tagged during winter in upper rearing areas of these streams $(\mathrm{s}=0.077)$. Upstream overwinter survival was $20 \%$. In the Lostine River, there was no significant difference in survival probabilities between early migrants $(s=0.329)$ and those tagged in winter in upper rearing areas $(s=0.277)$. Upstream overwinter survival was 41\%. Juvenile spring chinook salmon from the Minam River were detected at Lower Granite Dam from 8 April through 18 August 2001. Early migrants were detected earlier $($ median $=28$ April $)$ than late migrants (median $=14$ May) .

Spring chinook salmon parr that were collected by seining and PIT-tagged on Catherine Creek and the Imnaha, Lostine, and Minam rivers in summer 2000 were detected at Lower Granite Dam over an $87 \mathrm{~d}$ period from 8 April to 3 July 2001. The migratory period of individual populations ranged from $51 \mathrm{~d}$ (Imnaha River) to $67 \mathrm{~d}$ (Catherine Creek) in length. Median dates of migration ranged from 30 April (Imnaha River) to 17 May (Catherine Creek). We found significant differences in migration timing between these populations (Kruskal-Wallis $P<0.001)$. Median arrival dates for Lostine and Minam smolts were intermediate and not different from each other (medians $=9$ May and 8 May, respectively). Detection rates differed between populations. Catherine Creek detection rates were the lowest (8.2\%). Imnaha, Lostine, and Minam detection rates were not significantly different from each other $(18.0 \%, 20.7 \%$, and $22.1 \%$, respectively). A similar pattern was seen for survival probabilities. Minam and Lostine survival probabilities did not differ and were highest $(0.228,0.210$, respectively), followed by the Imnaha (0.181), then Catherine Creek with the lowest survival probability (0.087).

During the 2001 migration, there were no detections of any age- 2 smolts that had been PIT-tagged as parr on Catherine Creek and the Imnaha, Lostine, and Minam rivers in 1999. One age-2 smolt that was tagged on the Lostine River in January of 2000 was detected at the dams in 2001 . 
Using mark-and-recapture and scale-aging techniques, we determined population size and age-structure of spring chinook salmon parr in Catherine Creek and the Lostine River. In Catherine Creek, we estimated that 986 mature age-1 parr and 15,032 immature age- 0 parr were present during August 2001. An average of 26 mature age-1 parr were produced per redd constructed in 1999. An average of 578 immature age-0 parr were produced per redd constructed in 2000 . We estimated that $3.8 \%$ of the immature age- 0 parr inhabiting Catherine Creek in August 2000 matured and were present in Catherine Creek in August 2001. We estimated there were 7.5 mature male parr for every anadromous female spawner in Catherine Creek in 2001.

We estimated 33,086 immature, age-0 parr inhabited the Lostine River in August 2001. An average of 624 immature parr were produced per redd constructed in 2000. Mature male parr were observed, but not enough were marked to calculate a population estimate.

\section{Summer Steelhead}

We used mark-and-recapture and scale-aging techniques to determine population size and age-structure of $O$. mykiss in the mainstem Catherine Creek and its tributary North Fork Catherine Creek during the summer of 2001. We estimated that 25,736 O. mykiss inhabited the mainstem Catherine Creek and 10,338 O. mykiss inhabited the north fork. Scale analysis showed that $O$. mykiss ranged from age-0 to age-3 at both localities. Age- 1 fish were the most abundant, accounting for $86.7 \%$ in mainstem Catherine Creek and $55.9 \%$ in the north fork. O. mykiss that were PIT-tagged during the summer of 2000 in the mainstem, north fork, and south fork of Catherine Creek were detected at Lower Granite Dam between 25 April and 25 June 2001. Their detection rate was $2.5 \%$. No difference in size (measured when tagged in the summer) was detected between fish that migrated out of upstream rearing areas the following fall as opposed to the following spring. However, fish that migrated out of upstream rearing areas before the summer of 2001 were larger than all the summer tagged fish (medians $=127 \mathrm{~mm}, 113 \mathrm{~mm}$, respectively).

Juvenile O. mykiss were PIT-tagged at screw traps on Catherine Creek, and the upper Grande Ronde, Lostine, and Minam rivers during the fall of 2000 (early migrants) and spring of 2001 (late migrants). PIT-tagged fish were detected at Lower Granite Dam in 2001 between 12 April and 18 August. Early migrants from Catherine Creek reached Lower Granite Dam earlier $($ median $=6 \mathrm{May})$ than late migrants $($ median $=14$ May $)$. Their detection rates were $11.9 \%$ (early migrants) and 36.5\% (late migrants). Late migrants detected at the dams in 2001 were larger in fork length $($ median $=150 \mathrm{~mm})$ at tagging than all late migrants tagged (median $=141$ $\mathrm{mm}$ ). There was no difference in length between early migrants that were detected in 2001 $($ median $=139 \mathrm{~mm})$ and all early migrants tagged $($ median $=136 \mathrm{~mm})$. Median arrival date for early migrants from the upper Grande Ronde River was 7 May; and for late migrants was 5 May. Their detection rates were $19.7 \%$ (early migrants) and $41.7 \%$ (late migrants). Late migrants detected at the dams in 2001 were larger (median $=156 \mathrm{~mm}$ ) at tagging than all late migrants tagged (median $=146 \mathrm{~mm}$ ). Early migrants detected at the dams in 2001 were also larger $($ median $=152 \mathrm{~mm})$ at tagging than all early migrants tagged (median $=124 \mathrm{~mm})$. There was no difference in arrival dates of early migrants (median $=12$ May) and late migrants (median $=14$ 
May) from the Lostine River. Their detection rates were $4.0 \%$ (early migrants) and $53.3 \%$ (late migrants). Late migrants detected at the dams in 2001 were larger (median $=171 \mathrm{~mm}$ ) at tagging than all late migrants tagged (median $=160 \mathrm{~mm}$ ). Early migrants detected at the dams in 2001 were also larger $($ median $=161 \mathrm{~mm})$ at tagging than all early migrants tagged $($ median $=80 \mathrm{~mm})$. There was no difference in arrival dates of early migrants (median $=9$ May) and late migrants (median $=7$ May) from the Minam River. Their detection rates were $21.9 \%$ (early migrants) and $59.7 \%$ (late migrants). Late migrants detected at the dams in 2001 were larger (median $=167$ $\mathrm{mm}$ ) at tagging than all late migrants tagged (median $=159 \mathrm{~mm}$ ). There was no detectable difference in length between early migrants that were detected in 2001 (median $=147 \mathrm{~mm}$ ) and all early migrants tagged (median $=121.5 \mathrm{~mm}$ ).

Fifty-four O. mykiss were detected at Snake and Columbia River dams in 2001 that had been PIT-tagged during MY 2000 on Catherine Creek, the upper Grande Ronde, or the Lostine rivers.

The $O$. mykiss collected at traps ranged from 0 to 3 years of age. Most early migrants collected at the trap were age- 1 with few age- 0 or age- 2 migrants present. These age- 1 migrants would presumably resume their seaward migration the following spring as age-2 smolts. During the late migration period, the proportion of age- 2 migrants was greater but never reached over $50 \%$ of the total late migrant population. Of the fish with known ages that were PIT-tagged at the traps in MY 2001 and subsequently detected at Snake/Columbia River dams, most (91\%) reached the dams as age-2 smolts while four (9\%) were age-3. No age-1 smolts were detected in MY 2001.

\section{Management Implications and Recommendations}

The Grande Ronde Valley provides more than a migration corridor for juvenile spring chinook salmon. Although the proportion varies annually, large numbers of juveniles leave upper rearing areas in Catherine Creek and the upper Grande Ronde River in fall and overwinter in the Grande Ronde Valley. Rearing habitat in the valley is significantly altered and degraded. Four years of data for the upper Grande Ronde River population indicate salmon that overwinter in the valley survive at a higher rate than salmon that overwinter in upper rearing areas. Enhancing habitat conditions to improve overwinter survival in the Grande Ronde River valley should be given priority.

Juvenile spring chinook salmon that leave upper rearing areas in Catherine Creek and the upper Grande Ronde and Lostine rivers during fall overwinter in lower river reaches and arrive at Lower Granite Dam earlier in spring than juveniles that overwinter in upper rearing areas. As environmental conditions in the Snake and Columbia rivers vary throughout the smolt migration, survival may vary among fish exhibiting the different life histories. In general, early-migrating salmon have been detected at mainstem dams at rates similar to or higher than those for salmon that overwinter in upper rearing areas. However, in some years, detection rates for salmon that overwinter in upper areas have been greater for an individual population. These differences point out the need to maintain the diversity of life history strategies observed in the Grande 
Ronde River basin. What may be a successful strategy one year may not be as successful in another year under different conditions.

The differences that exist between local populations and life history types in migration timing at Lower Granite Dam demonstrate the need to manage the hydrosystem so as to maximize survival throughout the entire migratory period of Snake River spring/summer chinook salmon smolts. Maintenance of the remaining populations in the Grande Ronde River and Imnaha River basins, their specific life histories, and any unique genetic resources they possess is critical to the continued persistence of chinook salmon in northeast Oregon and elsewhere in the Snake River basin.

The information we have gathered thus far on the occurrence of age- 2 smolts indicates this life history is rare among northeast Oregon spring chinook salmon and, in terms of life cycle modeling at least, can probably be discounted. The mature male parr life history is more prevalent and deserves consideration from both life cycle modeling and biological perspectives. Based on the mature male parr to anadromous female spawner ratios we have observed, it is evident mature male parr hold the potential to make significant gametic contributions to northeast Oregon spring chinook salmon populations. Given the continual low abundance of adult spawners, mature male parr may be an important means by which the breeding population size is increased.

\section{INTRODUCTION}

The Grande Ronde River originates in the Blue Mountains of northeast Oregon and flows $334 \mathrm{~km}$ to its confluence with the Snake River near Rogersburg, Washington. Historically, the Grande Ronde River basin produced an abundance of salmonids including spring, summer and fall chinook salmon, sockeye salmon, coho salmon, and summer steelhead (ODFW 1990). During the past century, numerous factors have led to a reduction in salmonid stocks such that the only viable populations remaining are spring chinook salmon and summer steelhead. In addition, spring chinook salmon populations in the Grande Ronde River basin have diminished in size and are substantially depressed from historic levels. It is estimated that prior to the construction of the Snake and Columbia river dams, more than 20,000 adult spring chinook salmon returned to spawn in the Grande Ronde River basin annually (ODFW 1990). A spawning escapement of 12,200 adults was estimated for the basin in 1957 (USACE 1975). Recent population estimates vary from year to year, but remain at least an order of magnitude lower than historic estimates. In 1999, estimated escapement for the basin was 540 adults $(180$ redds $\times 3.0$ adults/redd). The range of spring chinook salmon spawning in the Grande Ronde River basin also has been constricted. Historically, spring chinook salmon were distributed among 21 streams, yet today most production is limited to only six tributaries, including the upper Grande Ronde River, Catherine Creek, Lookingglass Creek, the Minam River, the Lostine River and the Wenaha River (ODFW 1990).

Numerous factors are thought to have contributed to the decline of spring chinook salmon in the Snake River and its tributaries. These factors include juvenile and adult passage problems at mainstem Snake and Columbia river dams, cyclic changes in ocean productivity, overharvest, 
and habitat degradation associated with timber, agricultural, and land development practices. More than $80 \%$ of anadromous fish habitat in the upper Grande Ronde River is considered degraded (USFS 1992). Habitat problems throughout the Grande Ronde River basin (reviewed by Bryson 1993) include poor water quality associated with high sedimentation and poor thermal buffering, moderately to severely degraded riparian zones, and a decline in abundance of large pool habitat.

Precipitous declines in Snake River spring chinook salmon populations resulted in these stocks, including Grande Ronde River stocks, being listed as threatened under the Endangered Species Act (October 1992). Development of sound recovery strategies for these salmon stocks requires knowledge of stock-specific life history strategies and critical habitats for spawning, rearing, and downstream migration (Snake River Recovery Team 1993; NWPPC 1992; ODFW 1990). In addition, knowledge of juvenile migration patterns, smolt production and survival, and juvenile winter rearing habitat is needed within the basin. We currently are expanding our efforts to include life stage specific survival estimates (egg-to-parr, parr-to-smolt, and smolt-toadult), and an evaluation of the importance and frequency at which alternative life history tactics are utilized by spring chinook salmon populations in northeast Oregon.

Though historic estimates of juvenile production in the basin are lacking, given the dramatic decline in adult returns to the basin and the extent of habitat degradation, it is reasonable to assume that juvenile production is lower now than in the past. Recent parr-tosmolt survival estimates for populations in the Grande Ronde River basin range from 8.9\% to 22.1\% (Walters et al. 1993, 1994; Sankovich et al. 1995). These estimates are based on data from parr that were individually tagged with passive integrated transponder (PIT) tags in late summer and were detected at mainstem Snake and Columbia river dams. Before this study was initiated, it was not clear how much mortality occurred during the smolt migration and how much occurred during fall and winter rearing.

The spring chinook salmon smolt migration from the Grande Ronde River basin occurs in spring. Data from Lookingglass Creek (Burck 1993) and Catherine Creek, the Grande Ronde River and the Lostine River (Keefe et al. 1994, 1995; Jonasson et al. 1996, 1997, 1999; Tranquilli et al. 1998; and Monzyk et al. 2000) indicate a substantial number of juveniles move out of upper rearing areas during fall and overwinter downstream within the Grande Ronde basin. The proportion of the total migrant population these early migrants represent, and their survival to Snake and Columbia river dams, varies among years and streams.

Juveniles that leave upper rearing areas in Catherine Creek and the upper Grande Ronde River in fall overwinter in the Grande Ronde River valley. Much of the habitat in these midreaches of the Grande Ronde River is degraded. Stream conditions in the Grande Ronde River below La Grande consist of both meandering and channeled sections of stream, which run through agricultural land. Riparian vegetation in this area is sparse and provides little shade or instream cover. The river is heavily silted due to extensive erosion associated with agricultural and forest management practices and mining activities. It is reasonable to suggest that salmon overwintering in degraded habitat may be subject to increased mortality due to the limited ability of the habitat to buffer against environmental extremes. The fall migration from upper rearing areas in Catherine Creek constitutes a substantial portion of the juvenile production (Keefe et al. 
1995, Jonasson et al. 1996, 1997, 1999). Therefore winter rearing habitat quantity and quality in the Grande Ronde valley may be important factors limiting spring chinook salmon smolt production in the Grande Ronde River.

Numerous enhancement activities have been undertaken in an effort to recover spring chinook salmon populations in the Grande Ronde River basin. Supplementation programs have been initiated by the Oregon Department of Fish and Wildlife, the Confederated Tribes of the Umatilla Indian Reservation, and the Nez Perce Tribe using endemic broodstock from the upper Grande Ronde River, Catherine Creek, and Lostine River. Information we collect will serve as the foundation for assessing the effectiveness of programs currently underway.

\section{GOALS AND OBJECTIVES}

This study was designed to document and describe early life history strategies exhibited by spring chinook salmon and O. mykiss in the Grande Ronde River basin. The objectives of this study were to:

1. Document the in-basin migration patterns for spring chinook salmon juveniles in Catherine Creek and the upper Grande Ronde, Minam, and Lostine rivers, including the abundance of migrants, migration timing and duration.

2. Estimate and compare smolt detection rates and survival probabilities at mainstem Snake and Columbia river dams for early and late migrating spring chinook salmon from the tributary populations in Catherine Creek and the upper Grande Ronde, Lostine and Minam rivers.

3. Estimate and compare smolt detection rates and survival probabilities at mainstem Columbia and Snake River dams for migrants from four local, natural populations of spring chinook salmon in the Grande Ronde River and Imnaha River basins.

4. Document the annual migration patterns for spring chinook salmon juveniles from four local, natural populations in the Grande Ronde River and Imnaha River basins: Catherine Creek, Lostine, Minam, Imnaha rivers.

5. Determine survival to parr stage for spring chinook salmon in two local, natural populations in the Grande Ronde River basin: Catherine Creek and Lostine River.

6. Investigate the significance of alternate life history strategies of spring chinook salmon in two local, natural populations in the Grande Ronde River basin: Catherine Creek and Lostine River.

7. Document patterns of movement for juvenile O. mykiss from tributary populations in Catherine Creek, the upper Grande Ronde, Lostine and the Minam rivers. Include data on migration timing, duration, and smolt abundance. 
8. Estimate and compare smolt detection rates and survival probabilities to mainstem Columbia and Snake River dams for summer steelhead from four tributary populations: Catherine Creek and the upper Grande Ronde and Lostine, and Minam rivers.

9. Evaluate methods to estimate the proportion of $O$. mykiss captured during fall trapping that are migrating out of rearing areas and will undertake a smolt migration the following spring.

10. Describe the population characteristics of the juvenile $O . m y k i s s$ population in Catherine Creek.

\section{SPRING CHINOOK SALMON INVESTIGATIONS}

\section{Methods}

For the purpose of this report, we assume that all juvenile spring chinook salmon captured in traps were downstream "migrants". The term "migratory year" (MY) refers to the earliest calendar year juveniles were expected to migrate to the ocean. The term "brood year" (BY) refers to the calendar year eggs were fertilized. All spring chinook salmon referred to in this report were naturally produced unless noted otherwise.

\section{Egg-to-Parr Survival, Parr Abundance, and Age Composition in Summer}

We used mark-and-recapture and scale-aging techniques to estimate the abundance of immature and mature (male) parr, by age class, in Catherine Creek and the Lostine River in August 2001. We captured, marked, and released parr from 30 July to 2 August on Catherine Creek and 6-10 August on the Lostine River. We conducted subsequent sampling 6-10 August on Catherine Creek and 13-17 August on the Lostine River. Our goal for each stream was to mark 1,000 immature parr and as many mature parr as we could capture in $5 \mathrm{~d}$ (not to exceed 1,000). During subsequent sampling, our goal was to capture at least 500 immature parr and as many mature parr (not to exceed 500) as possible in $5 \mathrm{~d}$. We collected scales for age determination from the mature parr captured in each stream. Scales were not collected from immature parr in Catherine Creek and the Lostine River to minimize handling time and stress on the fish. Scale analysis in previous years indicated that most (98.9-100\% in Catherine Creek and $100 \%$ in the Lostine River) of the immature parr in these streams were age- 0 (Appendix Table A-1). We identified mature parr based on body morphology and coloration. Mature parr tended to be longer, deeper-bodied, and more yellowish in color (laterally) than immature parr. Precocious maturation of chinook parr has only been recorded in males. Therefore, all mature parr were assumed to be male. In Catherine Creek and the Lostine River, all parr that did not exhibit signs of early maturity were assumed to be immature, age- 0 parr.

Site Description: On both Catherine Creek and the Lostine River, parr were collected (and marked and released) upstream of rotary screw traps, in the length of stream encompassing the majority of the spawning and rearing habitat (Figure 1). Sampling on Catherine Creek 
occurred from the rotary screw trap (rkm 20) to the confluence of the north and south forks of Catherine Creek (rkm 52). Sampling on the Lostine River occurred from the rotary screw trap ( $\mathrm{rkm} 3$ ) to the Lostine Guard Station (rkm 30). We did not sample a $9 \mathrm{~km}$ long canyon within the study area on the Lostine River because it is unsuitable rearing habitat for juvenile spring chinook salmon, although adults do spawn upstream and downstream of this reach. The sampling area on Catherine Creek was divided into four reaches, based roughly on valley and channel morphology. We calculated separate population estimates for each reach. Catherine Creek reach 1 extended upstream from the screw trap (river kilometer, rkm, 32.2) to the Kirby's property (rkm 37.8). Reach 2 extended from the Kirby's property to the Highway 203 bridge just upstream of the artesian well (rkm 44). Reach 3 extended from the Highway 203 bridge to the Merry-Go-Round bridge (rkm 47.5). And, reach 4 extended from the Merry-Go-Round bridge to the North Fork - South Fork confluence (rkm 52).

Marking Phase: Parr were collected for marking along the length of Catherine Creek mentioned above. Parr were collected in 6 segments of stream (about $10 \mathrm{~km}$ total) scattered throughout the $27 \mathrm{~km}$ of spawning and rearing area on the Lostine River. In most cases, 2-3 snorkelers herded the parr downstream into a seine held perpendicular to the stream flow. Traditional beach seining was also effective in a few areas. Captured fish were held in aerated, $19 \mathrm{~L}$ buckets or in aerated, $19 \mathrm{~L}$ carboys attached to pack frames and transferred periodically to live cages anchored in shaded areas of the stream near our marking stations. Prior to being marked, fish were anesthetized in an aerated bath containing $40-50 \mathrm{mg} / \mathrm{L}$ of tricaine methanesulfonate (MS-222). We marked all mature parr, and any immature parr less than $55 \mathrm{~mm}$ fork length (FL), with diluted, non-toxic, acrylic paint. The paint was injected subcutaneously on the ventral surface slightly anterior of the pelvic fin insertion using a Panjet marking instrument (Hart and Pitcher 1969). Immature parr that were $55 \mathrm{~mm}$ FL or greater were either paint-marked or PIT-tagged. PIT tags were injected manually with a modified hypodermic syringe as described by Prentice et al. $(1986,1990)$ and Matthews et al. $(1990,1992)$. Syringes were disinfected for $10 \mathrm{~min}$ in $70 \%$ isopropyl alcohol and allowed to dry for $10 \mathrm{~min}$ between each use. We used a portable tagging station that consisted of a computer, PIT tag reader, measuring board, and electronic balance to record the tag code, fork length $( \pm 1 \mathrm{~mm})$, and weight $( \pm 0.1 \mathrm{~g})$ of PIT-tagged fish. We also recorded the fork length and weight of mature parr, and the fork length of paint-marked, immature parr. All fish were handled and marked at stream temperatures of $15^{\circ} \mathrm{C}$ or less and released in the area of capture on the day they were processed. Scale samples were collected from most of the mature parr that were handled.

Recapture Phase: Each reach on Catherine Creek was divided into sections approximately $0.4 \mathrm{~km}$ in length. Within each reach, we collected parr from 5-7 randomly selected sections. Approximately $9.4 \mathrm{~km}$ of Catherine Creek were resampled. Parr were resampled over the length of the Lostine River, from the rotary screw trap to the Lostine Guard Station, except for the $9 \mathrm{~km}$ long canyon section. We used the seining methods described above to capture parr. Each fish was inspected for marks and maturity status, and the numbers of mature and immature parr that were unmarked, paint-marked, PIT-tagged, or that had lost their PIT tag (i.e., no tag could be detected, but a recent PIT-tagging scar was evident) were recorded.

Calculations: We used Chapman's modification of the Petersen estimate (Ricker 1975) to determine the abundance of immature and mature parr in Catherine Creek and the Lostine 
River. We obtained 95\% confidence intervals (CI) using equation (3.7) in Ricker (1975) and values from Appendix II in Ricker (1975). Age composition estimates for the groups of mature parr were based on results from scale analyses. Scale impressions were made on acetate slides and inspected on a microfiche reader at $42 \mathrm{x}$ magnification. We counted annuli to determine whether parr were age- 0 (no annulus) or 1 (one annulus). We calculated the proportion of mature parr of each age and obtained 95\% confidence intervals from table P in Rohlf and Sokal (1995). Immature parr were assumed to be age-0 and their scales were not collected.

Using parr abundance and age composition estimates from August 2000 (Monzyk et al. 2000) and 2001, and redd count data from 1999 and 2000 spawning ground surveys (ODFW, unpublished data) we determined the following regarding spring chinook salmon populations in Catherine Creek and the Lostine River: 1) the abundance of immature and mature parr, by age class, in August 2001; 2) the percentages of immature, age-0 parr present in each stream in August 2000 that were present in August 2001 as mature or immature age-1 parr; 3) the average number of mature and immature, age- 0 parr (in 2001) produced per redd constructed in 2000; and 4) the average number of mature and immature age-1 parr (in 2001) produced per redd constructed in 1999. We estimated rates of egg-to-parr survival, based on an estimated fecundity of 4,348 eggs/female (mean fecundity of 12 female spring chinook salmon captured at the Lostine River weir and spawned at Lookingglass Hatchery in 1997 [4 fish] and 2000 [8 fish]; ODFW, unpublished data) and the number of redds counted above the trap sites on Catherine Creek and the Lostine River.

\section{In-Basin Migration Timing and Abundance}

The migration timing and abundance of juvenile spring chinook salmon in the upper Grande Ronde River, Catherine Creek, the Lostine River, and the Minam River were determined by operating rotary screw traps through out the migratory year. The 2001 migratory year (MY 2001) for spring chinook salmon within the Grande Ronde River basin overlaps two calendar years, and began on 1 July 2000 and ended on 30 June 2001. Spring chinook salmon in our study streams exhibit two migrational life-history patterns. Early migrants leave upper rearing areas in the fall and overwinter in downstream habitat before continuing their seaward migration out of the basin the following spring. Late migrants exhibit another life history strategy whereby they remain in upper rearing areas throughout fall and winter, and initiate their seaward migration in spring. Designations of early and late migratory groups were based on trends in capture rates at trap sites. A common period of diminished capture rates occurs at our trap sites in winter and was used to classify fish into migratory groups. We then determined migration timing and abundance by migratory group.

In the Grande Ronde River subbasin, one rotary screw trap was located below spawning and upper rearing areas in the upper Grande Ronde River near the town of Starkey at rkm 299 (Figure 1). A second trap was located in Catherine Creek below spawning and upper rearing areas near the town of Union at rkm 32. Catherine Creek enters the Grande Ronde River at rkm 225 and is an important tributary for spring chinook salmon spawning and rearing. A third rotary screw trap was located in the Grande Ronde River at the lower end of the Grande Ronde Valley near the town of Elgin at rkm 164. In the Wallowa River subbasin, one rotary screw trap 
was located below the majority of spawning and upper rearing areas on the Lostine River near the town of Lostine at rkm 3 (Figure 1). Although we attempted to fish the traps continuously through the year, there were times when a trap could not be operated due to low flow or freezing conditions. There were also instances when traps were not operating due to debris blockage and mechanical breakdowns. We did not attempt to adjust population estimates for periods when traps were not operating. For this reason, our estimates represent a minimum number of migrants.

The rotary screw traps were equipped with live boxes that safely held hundreds of juvenile spring chinook salmon trapped over 24-72 h periods. The traps were generally checked daily, but were checked as infrequently as every third day when only a few fish were captured per day and environmental conditions were not severe. All juvenile spring chinook salmon captured in traps were removed for enumeration and interrogated for PIT tags. We attempted to measure fork lengths $(\mathrm{mm})$ and weights $(\mathrm{g})$ of at least 100 juvenile spring chinook salmon each week. Prior to sampling, juvenile spring chinook salmon were anesthetized with MS-222 (40-60 $\mathrm{mg} / \mathrm{L})$. Fish were allowed to recover fully from anesthesia before release into the river. River height was recorded daily from permanent staff gauges. Water temperatures were recorded daily at each trap location using thermographs or hand held thermometers.

Migrant abundance was estimated by conducting weekly trap efficiency tests throughout the migratory year at each trap site. Trap efficiency was determined by releasing a known number of paint-marked or PIT-tagged fish above each trap and enumerating recaptures. Up to 100 juvenile spring chinook salmon were marked and released each week. On days when a trap stopped operating, the number of recaptured fish and the number of marked fish released the previous day were subtracted from the weekly totals.

Trap efficiency was estimated by

$$
\hat{E}=R / M
$$

where $\hat{E}$ is the estimated weekly trap efficiency, $R$ is the number of marked fish recaptured, and $M$ is the number of marked fish released upstream.

The weekly abundance of migrants that passed each trap site was estimated by

$$
\hat{N}=U / \hat{E}
$$

where $\hat{N}$ is the estimated number of fish migrating past the trap, $U$ is the total number of unmarked fish captured, and $\hat{E}$ is the estimated weekly trap efficiency. Total migrant abundance was estimated as the sum of weekly abundance estimates.

Variance of each weekly $\hat{N}$ was estimated by the one-sample bootstrap method (Efron and Tibshirani 1986; Thedinga et al. 1994) with 1,000 iterations. Preliminary analysis indicated that when there were less than 10 recaptured fish in a week, bootstrap variance estimates were greatly expanded. For this reason, we combined consecutive weeks when there were fewer than 10 recaptures until total recaptures were greater or equal to 10 fish. This combined trap efficiency estimate was used in the bootstrap procedure to estimate variance of weekly population estimates. Each bootstrap iteration calculated weekly $\hat{N}^{*}$ from equations ( 1 and 2 above) drawing $R^{*}$ and $U^{*}$ from the binomial distribution, where asterisks denote bootstrap 
values, and weekly variance of $\hat{N}^{*}$ was calculated from the 1,000 iterations. Weekly variance estimates were summed to obtain an estimated variance for the total migrant abundance.

Confidence intervals for total migrant abundance were calculated by

$$
95 \% C I=1.96 \sqrt{V}
$$

where $V$ is the estimated total variance determined from the bootstrap. Migrant fry were able to escape from the trap without detection and, therefore, were not included in migrant abundance estimates. Also, sexually mature male parr were not included in migrant abundance estimates.

The Catherine Creek trap and the Lostine River trap were located below hatchery spring chinook salmon release sites. The magnitude of hatchery spring chinook salmon releases into these streams during the spring necessitated modifications to our method of estimating migrant abundance of wild spring chinook salmon at the trap sites. During low catch periods, the trap was fished continuously throughout a $24 \mathrm{~h}$ period as described above. During high catch periods, the trap was fished systematically (each night) for a $4 \mathrm{~h}$ interval (Catherine Creek trap: 18:20 to 22:20; Lostine River trap: 20:00 to 24:00) using systematic two-stage sampling. Systematic sampling allowed us to reduce fish handling and overcrowding in the live box, and avoid labor-intensive $24 \mathrm{~h}$ trap monitoring. Preliminary $24 \mathrm{~h}$ sampling indicated a strong diel pattern in spring chinook salmon catch rates. The specific intervals were chosen because a relatively large proportion of the total daily catch was captured during these $4 \mathrm{~h}$ time blocks.

Systematic sampling required us to estimate the proportion of the total daily catch captured during our sampling interval. We estimated this proportion by fishing the trap over several $24 \mathrm{~h}$ periods prior to the hatchery release period. We counted the number of fish trapped during the $4 \mathrm{~h}$ interval and the remaining $20 \mathrm{~h}$ interval within each $24 \mathrm{~h}$ period. The proportion of the total daily catch captured during the sampling interval $(i)$ was estimated by

$$
\hat{P}_{i}=S_{i} / C
$$

were $\hat{P}_{i}$ is the estimated proportion of the total daily catch for sampling interval $i, S i$ is the total number of fish caught during sampling interval $i$, and $C$ is the total number of fish caught throughout the $24 \mathrm{~h}$ sampling periods.

We did not attempt to mark and release fish for the purpose of estimating trap efficiency during systematic sampling. Abundance of wild juvenile spring chinook salmon at each trap during the systematic sampling period was estimated by

$$
\hat{N}_{s}=\left(U_{i} / \hat{P}_{i}\right) / \hat{E} \text {; }
$$

where $\hat{N}_{s}$ is the estimated number of fish migrating past the trap during systematic sampling, $U_{i}$ is the total number of fish captured during interval $i, \hat{P}_{i}$ is the proportion of daily catch from equation (4), and $\hat{E}$ is the estimated trap efficiency. Trap efficiency during systematic sampling was calculated from equation (1) by using mark/recapture numbers from one week before and after the systematic sampling period. Abundance for the total migration at the Catherine Creek and Lostine River traps was determined by summing the continuous and systematic sampling estimates.

Variance for $\hat{N}_{s}$ at each trap during systematic sampling was estimated by the onesample bootstrap method (Efron and Tibshirani 1986; Thedinga et al. 1994) with 1,000 
iterations. Each bootstrap iteration calculated $\hat{N}_{s}$ from equations $\left(1,4\right.$, and 5) drawing $R$ and $S_{i}$ from the binomial distribution and $U_{i}$ from the Poisson distribution. Variance of total migrant abundance was determined by summing the variance from the continuous and systematic sampling estimates.

\section{Migration Timing and Survival to Lower Granite Dam}

PIT tag technology allows fish to be individually marked and subsequently observed without being sacrificed. First-time detections of PIT-tagged fish at Snake and Columbia River dams were used to estimate migration timing and index survival for each tag group. There were four tag groups for which we estimated migration timing and indexed survival to Lower Granite Dam: the summer tag group (upstream summer-rearing fish), the fall tag group (early migrants, overwintering downstream), the winter tag group, and the spring tag group (late migrants, overwintering upstream). The summer tag groups consisted of age- 0 parr tagged during July and August 2000 in their upstream rearing habitat. Fish were caught and PIT-tagged using techniques described in Egg-to-Parr Survival, Parr Abundance, and Age Composition in Summer. Summer tag groups were tagged on Catherine Creek, and the Lostine, Minam, and Imnaha rivers. For consistency with previous years' data, fish tagged as they moved downstream past our upper trap sites between September and early December 2000 were designated the fall tag group. Fall tag group fish were tagged at our screw traps on the Lostine, Grande Ronde, and Minam rivers and Catherine Creek. Fish tagged as they moved downstream past our upper trap sites between February and May 2001 were designated as the spring tag group. The spring tag group fish were tagged at our screw traps on the Lostine, Grande Ronde, and Minam rivers and Catherine Creek. These dates encompassed a majority of the early and late migrations. There was very little downstream migration past our traps during December and January, although a few juvenile spring chinook salmon were caught. Winter tag group fish were tagged immediately following completion of tagging of the fall tag group. These fish were caught and tagged a minimum of $8 \mathrm{~km}$ above the trap sites to minimize the chance they would pass the trap sites while making localized movements during winter. Winter groups were tagged on the Lostine River and Catherine Creek and were caught using dip nets while snorkeling at night. We attempted to PIT-tag 500 parr for fall, winter, and spring tag groups, and 500 or 1,000 parr for each summer tag group.

With the exception of the summer tag group, fish tagged in the different tag groups represented unique life history strategies. The summer tag group included fish that moved out of upper rearing areas as either early or late migrants, and consequently overwintered in either the lower or upper rearing areas. Therefore, the summer tag group included fish that exhibited both migrational patterns and represented timing and survival for the overall population. The fall tag group represented early migrants that left the upstream rearing areas in the fall and overwintered downstream of our screw traps. Both the winter and spring tag groups represented late migrants that overwintered as parr upstream and migrated out in the spring. The difference between the two groups was that the winter tag group was tagged earlier (December) than the spring tag group (February-May) and therefore experienced overwinter mortality in the upper rearing areas. 
During the 2001 migratory year, PIT tag interrogation systems were used in juvenile bypass systems at six of eight Snake River and Columbia River dams to monitor fish passage. Fish were also interrogated for PIT tags upon capture in our screw traps. All recaptured and interrogated fish were identified by their original tag group, insuring the independence of tag groups for analysis. For example, dam detections of fish that were tagged as part of the summer tag group and subsequently recaptured at a river trap as early migrants, were analyzed as summer tagged fish. At the completion of the 2001 migratory year, we obtained cumulative first-time detection information from PIT tag interrogation sites at Lower Granite, Little Goose, Lower Monumental, McNary, John Day, and Bonneville dams.

Calculations: Migration Timing: We estimated the timing of migration past Lower Granite Dam for each tag group by expanding daily numbers of PIT tag detections according to the proportion of river flow spilled each day. This procedure was necessary because some fish may have passed undetected over the spillway and the amount of spill varies throughout the migration season. We assumed the proportion of fish that passed over the spillway (spill effectiveness) was directly related to the proportion of flow spilled. This assumption conforms fairly well to data obtained using non-species-specific hydroacoustic methods (Kuehl 1986). We also assumed there was no temporal variation either in the proportion of fish diverted from turbine intakes into the bypass system (fish guidance efficiency) or in the proportion of fish that passed through the surface bypass collector. We made these assumptions in light of evidence to the contrary (Giorgi et al. 1988, Swan et al. 1986, Johnson et al. 1997) because the data required to account for such variation were unavailable. The extent to which our results may be biased would depend on the overall rates of fish passage via the bypass system and surface bypass collector, and on the degree to which daily rates of fish passage by these routes may have varied throughout the migration seasons. The number of fish migrating past Lower Granite Dam by week was calculated by multiplying the number of fish detected each day by a daily expansion factor, which was calculated as:

$$
\text { Expansion factor }=(\text { powerhouse flow }+ \text { spillway flow }) / \text { powerhouse flow. }
$$

Daily products were added for each week and rounded to the nearest integer. Median, first, and last detection dates were reported for each tag group. Medians were determined for detection dates weighted by expanded fish numbers. Median detection dates for the spring tag groups may have reflected the dates fish were tagged in addition to the migration pattern. For this reason, median detection dates for the spring tag groups may have been biased. The time taken for spring tagged parr to reach Lower Granite Dam from the screw trap was summarized for each location.

Survival Indices: For each tag group we calculated two different indices of survival to Lower Granite Dam. These were dam detection rates and Cormack-Jolly-Seber (CJS) survival probabilities. We calculated detection rates for each tag group by dividing the number of firsttime PIT-tag detections at all dams by the number of PIT-tagged fish released in each tag group. These detection rates were not adjusted to compensate for fish that may have passed through the hydrosystem without being detected. Therefore, the detection rates were relative and represented the minimum rate for each tag group. We also used the CJS method in the SURPH 2.1 program to calculate the probability of survival to Lower Granite Dam for fish in each tag group (Lady et 
al. 2001). This method took into account the probability of detection when calculating the probability of survival (detection probability $=$ capture probability $\times$ survival probability). Both detection rates and CJS survival probabilities were reported to allow comparison to previous years' detection rate data.

Comparison of Early Life History Strategies: Comparisons were made between early and late migrants from each location to determine if different life histories were associated with differences in timing of migration and survival to Lower Granite Dam.

Migration Timing: Lower Granite Dam detection dates were compared between the fall (early migrants) and winter (late migrants) tag groups from Catherine Creek and the Lostine River to investigate differences in seaward migration timing between the two life history strategies. Comparisons were made using the Mann-Whitney rank sum test on detection dates. Spillway flow, although minimal during this migratory year, was taken into account by rounding the expanded fish numbers to the nearest integer and creating duplicate 'dummy' detection records for any date with an expanded fish number greater than one. For the Minam River, we compared the detection dates for the fall and spring tag groups because parr were not tagged in the winter. We used the Pearson product moment correlation to determine whether the number of parr tagged at the Minam River trap in the spring, by week, was correlated to the number estimated to migrate past the trap. This was done to determine the likelihood that the late migrant median detection date was reflective of the true migration pattern rather than an artifact of the dates of tagging. Detection dates were not compared for early and late migrants from the upper Grande Ronde River due to small sample sizes.

Survival Indices: Fish that emigrated from upper rearing areas at different times of year and overwintered in different habitats were subject to different environmental conditions. Survival may have varied among fish exhibiting the different life histories as a result. For each stream, we evaluated relative success of early and late migrants by using the Maximum Likelihood Ratio Test to test the null hypothesis that survival probabilities of the fall tag group (early migrants) and the winter tag group (late migrants) were the same. We assumed that any difference in survival probabilities between these two groups was due to differential survival in upstream (used by winter tag group) and downstream (used by fall tag group) overwintering habitat.

We were able to use the spring tag group and the winter tag group survival probabilities to indirectly estimate overwinter survival probability for late migrants in the upstream rearing habitat on the Lostine River and Catherine Creek. Overwinter survival probability was calculated by dividing the winter tag group survival probability by the spring tag group survival probability (survival of winter tag group = late migrant overwinter survival $\mathbf{x}$ survival of spring tag group). Analogous calculations were performed using the detection rates for comparison with previous years' data.

Population Characteristics and Comparisons: The summer tag groups included the various life history patterns displayed by that population and provided information about the population's overall survival and timing of the smolt migration past the dams. In summer of 2000 and 2001, we PIT-tagged parr from populations in Catherine Creek and the Lostine, 
Minam, and Imnaha rivers in order to monitor and compare their migration timing as smolts to Lower Granite Dam, their rates of detection in the hydrosystem, and their survival probabilities from tagging to the dams on the mainstem Snake River. We conducted tagging operations in late summer (Table 1) so that most fish would be large enough to tag ( $\geq 55 \mathrm{~mm}$ FL). Sampling occurred primarily in areas where spawning adults were concentrated the previous year (Figure 1). The collection and PIT-tagging methods were previously described for the mark-and-recapture studies (see Methods; Egg-to-Parr Survival, Parr Abundance, and Age Composition in Summer). We caught, PIT-tagged, and released between 490 and 1,050 parr per stream in summer 2000; and between 501 and 1,001 in summer 2001 (Table 1, for all years see Appendix Table A-2). Information on the migration timing and detection rates of parr PIT-tagged in summer 2001 will be reported next year.

Migration Timing: We determined if migration timing differed between populations using a Kruskal-Wallis one-way analysis of variance on ranked dates of detection, expressed as day of the year, of expanded fish numbers. (The expansion factor was 1 for all summer 2000tagged fish migrating in 2001 because there was no spill at Lower Granite Dam for most of the migration period.) When significant differences were found, we used Dunn's pair-wise multiplecomparison procedure $(\alpha=0.05)$ to further analyze the data (SPSS Inc. 1992-1997).

Survival Indices: A $\chi^{2}$ contingency table analysis was performed to test the null hypothesis that detection rates were the same for all populations (Zar 1984, equation 6.1). If detection rates differed, a Tukey-type multiple comparison on transformed proportions was used to determine which populations differed (Zar 1984, equation 22.13). Survival probabilities were compared between populations using the modeling and hypothesis testing capabilities of Surph 2.1. Several models were developed. The ones that best fit the data were selected using Akaike's information criterion. Final model selection was made using likelihood ratio tests.

\section{Results and Discussion}

\section{Egg-to-Parr Survival, Parr Abundance, and Age Composition in Summer}

Catherine Creek: We estimated that 986 (95\% CI: 545 to 1,971) mature parr and 15,032 (95\% CI: 12,598 to 17,931) immature parr inhabited Catherine Creek in August 2001 (Table 2), based on mark-recapture data for the whole study area. This immature parr estimate was lower than the 2000 estimate of 25,997 (Appendix Table A-3). The mature parr estimate was not different than the 2000 estimate. Reach 2, which encompassed the Catherine Creek State Park area, was estimated to have the highest density of parr with 1,089 parr $/ \mathrm{km}$ (Table 3). Results from scale analyses indicated that all of the mature parr were age-1 (Table 4).

There were 38 and 26 redds counted in the Catherine Creek study area in 1999 and 2000, respectively (ODFW, unpublished data). We estimated that 26 mature, age-1 parr were produced per redd constructed in 1999 (Appendix Table A-4). In relation to the estimated number of eggs laid in 1999 , we estimated that $0.6 \%$ became parr that remained in freshwater and matured precociously at age- 1 . We estimated that 578 immature, age- 0 parr were produced from each redd constructed in 2000. This was equivalent to an egg-to-parr survival of $13.30 \%$ (95\% CI: 
11.14 to $15.86 \%$ ), which was similar to the 1998 and 1999 (brood year) egg-to-parr survival estimates of 15.23 and $15.55 \%$ respectively and greater than the 1997 survival rate (Table 5). Of the 25,698 immature, age- 0 parr estimated to be present in Catherine Creek in August 2000 (Monzyk et al. 2000), 3.84\% were estimated to be present as mature, age-1 parr in August 2001 (Appendix Table A-5).

We estimated that there were 7.5 mature, wild, male parr present in the late summer of 2001 for each redd counted a month or two later (see Alternate Life History Strategies for discussion). We observed 21 mature, hatchery, male parr during our field work in the summer of 2001.

Lostine River: We estimated that 33,086 (95\% CI: 25,901 to 42,226) immature parr inhabited the Lostine River in August 2001 (Table 2). We observed mature parr, but did not capture enough to estimate their population. Although we only aged scales from four fish, results indicated that there were age- 0 ( 1 fish) and age-1 (3 fish) mature parr in the Lostine River (Table 4). All mature parr caught in previous years (1998-2000) were age-1 (Appendix Table A-1). Scales were not taken from immature parr. All immature parr in previous years (1998-2000) were age-0 (Appendix Table A-1). For further calculations, we assumed that all immature parr in 2001 were also age- 0 .

There were 45 and 53 redds counted in the Lostine River study area in 1999 and 2000, respectively (ODFW, unpublished data). We estimated that 624 immature, age- 0 parr were produced from each redd constructed in the Lostine River in 2000 (Appendix Table A-4). This was equivalent to an egg-to-parr survival of $14.36 \%$ (95\% CI: 11.24 to $18.32 \%$,), which was higher than the 1999 egg-to-parr survival of $6.32 \%$ (Table 5). Although mature parr were present in the Lostine River, they were not as abundant here as in Catherine Creek and we were unable to calculate production per redd for mature parr or the percentage of age- 0 immature parr that remained in freshwater and matured precociously at age-1. Presumably, both values were very small but not zero. We observed two mature, hatchery, male parr during our 2001 summer field work.

\section{In-Basin Migration Timing and Abundance}

For the 2001 migratory year (MY 2001), distinct early and late migration patterns were evident at most of our upper trap sites with very few fish caught in the winter months (Figure 2). For the purpose of this report, early migration was considered to encompass the time from 1 July 2000 through 28 January 2001 (end of Julian week 4) and late migration from 29 January 2001 through 30 June 2001. For trap sites where we have previous years of data, the median emigration dates for MY 2001 early migrants tended to occur earlier than in past years while median emigration dates for late migrants tended to occur later than in previous years of this study (Table 6).

Upper Grande Ronde River: The upper Grande Ronde River trap fished for $183 \mathrm{~d}$ from 1 July through ice-up on 11 November 2000, and from 18 March through 30 June 2001. Very few migrants were collected at the trap site in MY 2001 (Table 7). During the early migration 
period, only two individuals were collected, thereby precluding us from determining a meaningful median migration date. During the late migration period, juvenile spring chinook salmon were collected on 12 separate days. The median emigration date for late migrants passing the trap was 10 April and was slightly later than past observations with the exception of MY 1997 (Table 6).

We estimated a minimum of 51 juvenile spring chinook salmon migrants (95\% CI: \pm 31 ) moved out of the upper Grande Ronde rearing areas during MY 2001. This estimate is similar to the MY 1997 estimate of 82 fish but considerably less than estimates from other years of this study that have ranged from 1,118 to 25,378 fish (Table 6). The low number of juvenile spring chinook salmon in MY 2001 was not unexpected given that the majority of these fish were produced from the returning adults of the MY 1997 cohort.

Based on weekly trap efficiencies, we estimated that approximately $12 \%(6 \pm 9)$ of the juvenile spring chinook salmon were early migrants and $88 \%(45 \pm 30)$ were late migrants. Even with the few migrants passing the trap, the pattern of a dominant late migration in the upper Grande Ronde is consistent for all migratory years studied to date with the exception of MY 1997, when $17 \%$ of the migrants moved late (Table 6). It is worth mentioning, however, that only 29 fish were trapped in MY 1997.

Catherine Creek: The Catherine Creek trap fished for $235 \mathrm{~d}$ from 1 July through ice-up on 6 December 2000, and from 20 February through 30 June 2001 (Table 7). There was a distinct early and late migration exhibited by juvenile spring chinook salmon at this trap site (Figure 2). Median emigration date for early migrants past the trap was 8 October. This was earlier than the median dates from previous years of this study (Table 6). The median emigration date for late migrants was 24 March and was only slightly later than median emigration dates from previous years of this study (Table 6).

We estimated that a minimum of $21,937 \pm 2,330$ juvenile spring chinook salmon migrants moved out of the upper Catherine Creek rearing areas during MY 2001. This estimate falls within estimates from previous years of this study (Table 6). Based on weekly trap efficiencies, $87 \%(18,996 \pm 2,213)$ migrated early and $13 \%(2,941 \pm 728)$ migrated late. The proportion leaving as late migrants was within the range observed in previous years of this study (Table 6). The Catherine Creek population appears to be different from the upper Grande Ronde population with respect to the proportion of early and late migrants. In contrast with upper Grande Ronde River, the largest outmigration from Catherine Creek has consistently been observed with early migrants (Table 6).

Grande Ronde Valley: The Grande Ronde Valley trap fished for 162 d from 4 October 2000 through 12 January 2001, and 1 February through 20 June 2001 (Table 7). A distinct late migration was evident; few fish passed the trap in fall and winter (Figure 2). The median emigration date was 22 April and was similar to timing observed in MY 1995, MY 1996 and MY 1998. Timing in MY 1997, MY 1999 and MY 2000 was somewhat later with the median migrant moving past this trap in early May. 
We estimated that a minimum of 3,376 $\pm 1,300$ juvenile spring chinook salmon migrants left the Grande Ronde Valley during MY 2001. There were numerous trap stoppages during the peak migration period because of debris blockage and mechanical breakdowns. Therefore, we most likely underestimated the number of juvenile spring chinook salmon migrating past this site. We estimated $152 \pm 94$ juvenile spring chinook salmon passed the trap as early migrants. As in the past five years, approximately $95 \%$ of the spring chinook salmon passed our trap as late migrants. These data indicate most juvenile spring chinook salmon that left the upper rearing areas during fall overwintered in the valley reaches of the Grande Ronde River above the trap site (rkm 164). Protection and enhancement of habitat in the Grande Ronde Valley should be given high priority to maintain or enhance overwinter survival of juvenile spring chinook salmon that reside in the valley during winter.

Lostine River: The Lostine River trap fished for 323 d between 1 July 2000 and 30 June 2001 (Table 7). Distinct early and late migrations were evident (Figure 2), with few fish captured during summer and winter. The median emigration date of early migrants was 29 September 2000. This date was earlier than the median emigration dates observed from previous years of this study (Table 6). The earlier migration timing was due in part to a relatively large number of juvenile spring chinook salmon moving past the trap in early July (Figure 2). The median date for late migrants was 20 April 2001 and was only slightly later than observed in past years of this study (Table 6). We estimated that a minimum of 13,610 $\pm 1,362$ juvenile spring chinook salmon migrants moved out of the Lostine River during MY 2001. We estimated approximately $77 \%(10,478 \pm 1,246)$ of the juvenile spring chinook salmon migrated early and $23 \%(3,132 \pm 549)$ migrated late. In past years of this study, the proportion leaving as late has ranged from $32 \%$ to $52 \%$ (Table 6 ).

Minam River: The Minam River trap fished for $139 \mathrm{~d}$ from 27 September through 16 November 2000, and 22 February through 18 June 2001. Distinct early and late migrations were evident (Figure 2), with few fish captured during summer and winter. The median emigration date of early migrants was 8 October 2000. The median date for late migrants was 27 March 2001. We estimated that a minimum of $28,209 \pm 4,643$ juvenile spring chinook salmon moved out of the Minam River during MY 2001. Approximately 36\% $(10,224 \pm 2,820)$ of the juvenile spring chinook salmon migrated early and $64 \%(17,985 \pm 3,689)$ migrated late. The early migrant estimate may not be accurate. More early migrants may have moved past our trap than reported here because the trap was not started until late September, thereby potentially missing some of the early migration.

Size of Migrants: A comparison of mean lengths and weights of juvenile spring chinook salmon captured in the traps as early and late migrants and in upper rearing areas in winter and those PIT-tagged and released are given in Tables 8-15. Length frequency distributions of juvenile spring chinook salmon caught in all traps by migration period are shown in Figures 3-7.

Weekly mean lengths of migrants increased over time at each of the traps (Figure 8). As in previous years, migrants captured at the Grande Ronde Valley trap generally were larger than fish captured at the upper Grande Ronde River and Catherine Creek traps in MY 2000. A similar pattern emerges in Catherine Creek and Lostine River in which the average length of spring chinook salmon collected at our traps increases during the summer months, reaches an early peak 
in the fall, and decreases slightly by winter (Figure 8). This early peak may indicate that larger individuals in the rearing population have a greater propensity to emigrate as early migrants or migrate sooner than smaller individuals during the early migration period. Larger individuals have been found to migrate sooner than smaller fish in natural populations of spring chinook salmon and coho salmon Oncorhynchus kisutch (Scrivener et al. 1994; Irvine and Ward 1989). Similarly, larger hatchery chinook salmon have been found to migrate sooner than smaller individuals (Ewing et al. 1984; Beckman et al. 1998).

\section{Migration Timing and Survival to Lower Granite Dam}

Juvenile spring chinook salmon were PIT-tagged at screw traps on Catherine Creek and the upper Grande Ronde, Lostine, and Minam rivers. Parr were also PIT-tagged upstream of the screw traps on Catherine Creek and the Lostine River during the winter. Because of the low number of juveniles collected at the upper Grande Ronde River trap during the 2001 migratory year, no early-migrating and only six late-migrating spring chinook salmon juveniles were PITtagged. At the Catherine Creek trap, we PIT-tagged 508 early- and 328 late-migrating spring chinook salmon juveniles that were not previously tagged. In addition, we PIT-tagged 498 spring chinook salmon parr during August 2000 and 522 parr during December 2000 in rearing areas upstream of the trap. At the Lostine River trap, we PIT-tagged 498 early- and 442 latemigrating juvenile spring chinook salmon that were not previously tagged. In addition, 489 parr were tagged in August 2000 and 499 parr in December 2000 from rearing areas above the trap. At the Minam River trap, we PIT-tagged 300 early- and 536 late-migrants that were not previously tagged. In addition, 1,000 parr were PIT-tagged in the Minam River and 1,050 in the Imnaha River in upstream rearing areas during August 2000 (Table 1).

Comparison of Early Life History Strategies: Migration Timing: Median arrival dates at Lower Granite Dam for the fall, winter, and spring tag groups PIT-tagged on Catherine Creek were 10 May, 1 June, and 30 May 2001, respectively (Figure 9 and Appendix Table A-6). Median arrival dates at Lower Granite Dam for the fall, winter, and spring tag groups on the Lostine River were 27 April, 14 May, and 12 May 2001, respectively (Figure 10). Median arrival dates at Lower Granite Dam for the fall and spring tag groups on the Minam River were 28 April and 14 May 2001, respectively (Figure 11). Four of the six fish tagged for the spring tag group on the upper Grande Ronde River were detected at Lower Granite Dam, with the median detection date of 17 May (Figure 12). Median detection dates of the spring tag groups may have reflected dates of tagging in addition to the timing of migration, therefore median detection dates for winter tagged parr were probably more representative of the 'late migrant' life history.

As in past years, the early migrants, which were tagged during fall and overwintered in lower rearing areas, reached Lower Granite Dam earlier than late migrants (winter tag group) from Catherine Creek and Lostine River (Mann-Whitney rank sum test, $P<0.001$, both locations). On the Minam River, we did not have a winter tag group to compare with early migrants. However, early migrants from the fall tag group reached Lower Granite Dam earlier than the late migrants in the spring tag group (Mann-Whitney rank sum test, $P<0.001$ ). On the upper Grande Ronde River, we did not have a fall or winter tag group to compare with the spring tag group. 
Travel times from the screw trap to Lower Granite Dam for late migrants in the spring tag group from the upper Grande Ronde River ranged from 29 to $56 \mathrm{~d}$ with a mean of $39.9 \mathrm{~d}(n=4)$ (Appendix Table A-7). This was slightly shorter than travel times reported in previous years of this study (range: 44-57 d). Travel times for late migrants from Catherine Creek ranged from 15 to $110 \mathrm{~d}$ with a mean of $63.7 \mathrm{~d}(n=100)$. This was slightly longer than travel times reported from previous years of this study (range: 54-61 d). Travel times for late migrants from the Lostine River ranged from 5 to $90 \mathrm{~d}$ with a mean of $23.6(n=246)$. Data from the past four years indicated travel times have remained relatively constant for fish from this population. Travel times for late migrants from the Minam River ranged from 9 to $106 \mathrm{~d}$ with a mean of 38.9 ( $n=$ 274).

Survival Indices: Detection rates at Snake and Columbia River dams for the fall, winter and spring tag groups from Catherine Creek were 0.128, 0.069, and 0.360, respectively (Table 16 and Appendix Tables A-8 and A-9). Detection rates for the fall, winter and spring tag groups from the Lostine River were 0.329, 0.277, and 0.663, respectively. Detection rates for fall and spring tag groups from the Minam River were 0.420 and 0.605 , respectively. Five of the six parr from the spring tag group on the upper Grande Ronde were detected resulting in a detection rate of 0.833 .

Survival probabilities to Lower Granite Dam for the fall, winter and spring tag groups from Catherine Creek were 0.130, 0.077, and 0.376, respectively (Table 16 and Appendix Table A-9). Survival probabilities for the fall, winter and spring tag groups from the Lostine River were $0.335,0.284$, and 0.689 , respectively. Survival probabilities for the fall and spring tag group from the Minam River were 0.427 and 0.619 , respectively.

Detection rates and CJS survival probabilities for Catherine Creek, Lostine, and Minam River fish were highest for the spring tag group (Table 16). We anticipated that this tag group would have the highest survival because it was the only tag group not subject to overwinter mortality after tagging.

For each stream, the survival probability of the fall tag group was compared to that of the winter tag group to determine whether downstream or upstream overwintering habitat conferred better survival. Fish from the fall tag group on Catherine Creek had a higher survival probability than fish from the winter tag group (Maximum Likelihood Ratio Test, $P=0.009$, Appendix Table A-10), suggesting better survival for fish that overwintered in the Grande Ronde Valley. This agreed with the results from previous years. The comparison of survival probabilities suggested that downstream habitat conferred better overwinter survival (MY 1997, MY 2000, MY 2001) or that there was no significant difference between upstream and downstream environment in regards to overwinter survival (MY 1995, MY 1996, MY 1998). MY 1999 was the only year in which upstream habitat conferred better overwinter survival. The overwinter survival of fish overwintering in the upper rearing areas was approximately 20\% for BY 1999. This rate was one of the lowest observed for Catherine Creek during the past six years of this study (Appendix Table A-11). 
In the Lostine River, survival probabilities of the fall tag group and winter tag group were not significantly different (Maximum Likelihood Ratio Test, $P=0.090$ ). This was in agreement with most of the previous years' results (Appendix Table A-10). For migratory years 19972001, survival probabilities only differed between upstream and downstream overwintering fish for MY 1998 and MY 1999, when fish overwintering downstream had a higher survival. The overwinter survival of fish overwintering in the upper rearing areas on the Lostine River was approximately $41 \%$ for BY 1999 . This rate is equal to the lowest rate observed for Lostine River during the past five years (Appendix Table A-11).

Population Comparisons: The summer tag groups included the various life history patterns exhibited by a population and allowed us to compare survival and timing between populations and over the years.

Migration Timing: Spring chinook salmon parr that were captured with seines and PITtagged on Catherine Creek and the Imnaha, Lostine, and Minam rivers in summer 2000 were detected at Lower Granite Dam over an $87 \mathrm{~d}$ period from 8 April to 3 July 2001 (Figure 13 and Appendix Table A-12). The migratory period of individual populations ranged from 51 days (Imnaha River) to 67 days (Catherine Creek) in length. Median dates of detection ranged from 30 April (Imnaha River) to 17 May (Catherine Creek).

Median detection dates differed between populations (Kruskal-Wallis, $P<0.001$ ). The median detection date for the Catherine Creek population was the latest (Dunn's pair-wise multiple comparison, $P<0.05)$. The median detection date for the Imnaha population was the earliest $(P<0.05)$. Median detection dates for the Lostine and Minam populations were intermediate and not significantly different from each other $(P>0.05)$. That timing has and continues to differ between populations demonstrates the need to manage the hydrosystem so as to maximize survival throughout the entire migratory period of Snake River spring/summer chinook salmon smolts.

Our findings for migratory year 2001 were generally consistent with past observations (Sankovich et al. 1996; Walters et al. 1997; Tranquilli et al. 1998; Jonasson et al. 1999, Monzyk et al. 2000) (Figure 14). For the Catherine Creek, Imnaha River, and Lostine River populations, the median dates of migration in 2001 fell within the range in medians observed from 1993 to 2000. The median migration date for the Minam River population was later than the medians for 1993 to 2000.

Survival Indices: Of the parr PIT-tagged on Catherine Creek and the Imnaha, Lostine, and Minam rivers during the summer of 2000, 8.2\%, 18.0\%, 20.7\%, and $22.1 \%$ (respectively) were detected in the hydrosystem in 2001 (Table 17). These detection rates were significantly different $\left(\chi^{2}, P<0.001\right)$. The detection rate of parr PIT-tagged on Catherine Creek was lower than detection rates for those tagged on the Imnaha, Lostine, and Minam rivers (Tukey type multiple comparison on transformed proportions, $\alpha=0.05)$. Detection rates did not differ between Imnaha and Lostine parr, or between Lostine and Minam parr $(\alpha=0.05)$.

Cormack-Jolly-Seber survival probabilities, which took into account the chance that a passing PIT-tagged fish may not have been detected, were 0.087 for parr tagged in Catherine 
Creek, 0.181 for Imnaha parr, 0.210 for Lostine parr, and 0.228 for Minam parr. To test for differences in survival probabilities between populations, several models were developed. The best model (Catherine $\neq$ Imnaha $\neq$ Lostine $=$ Minam) was selected using Akaike's information criterion. This model (null) was tested against the full model (Catherine $\neq$ Imnaha $\neq$ Lostine $\neq$ Minam) using the maximum likelihood ratio test. The null model was accepted $(P=0.43)$, supporting the conclusion that the survival probabilities of the Lostine and Minam populations were the highest and didn't differ significantly from each other. The survival probability of the Imnaha population was intermediate and that of the Catherine Creek population was the lowest (Table 17).

The detection rate for Catherine Creek parr was the lowest seen over the years of this study and appeared to continue a downward trend observed since MY 1998 (Figure 15 and Appendix Table A-9). The detection rate for the Lostine River parr was higher than or equal to rates observed in previous years. The detection rate for the Minam River parr was higher than rates observed in previous years. The detection rate for the Imnaha River parr was higher than the past two years, but in the middle of the range of detection rates for all the years of the study.

\section{Alternate Life-History Strategies}

In northeast Oregon streams almost all of the spring chinook salmon parr migrate seaward as age- 1 smolts. Most spend two to three years in the ocean before returning to their natal streams as mature adults to spawn. Over the years of this investigation we have observed two life-history strategies that deviate from this generalized pattern: seaward migration of smolts at age- 2 and maturation of age- 0 and age- 1 parr in freshwater.

Very few of the PIT-tagged spring chinook salmon parr from our study streams have smolted as two year olds (for discussion of this see Monzyk et al. 2000). Of the 33,244 parr PITtagged on Catherine Creek and the Grande Ronde, Imnaha, Lostine, Minam, and Wenaha rivers during the summers from 1992 to 1999 (Walters et al. 1992, 1997; Sankovich et al. 1996; Tranquilli 1998, Monzyk et al. 2000), only $11(0.03 \%)$ were detected in the hydrosystem as age2 smolts. We estimated that 1.1\% (299) of the immature parr in Catherine Creek during the summer of 2000 were age-1. These fish would have smolted in 2001 at age-2, or they could have matured precociously in the fall of 2000 and never migrated (as suggested by Monzyk et. al. 2000). During the 2001 migratory year, there were no detections of age- 2 smolts that had been PIT-tagged as age- 0 parr in the summer of 1999 or age-1 parr in the summer of 2000 on Catherine Creek or the Imnaha, Lostine, or Minam rivers. However, one age- 2 smolt was detected at the dams during the spring of 2001. This smolt was originally tagged in January of 2000 on the Lostine River and was expected to smolt during the spring of 2000, presumably as a one year old (scales were not taken). Its length (102 mm FL) was within, but at the upper end of, the length range of other parr tagged on the Lostine during the winter of 2000 and detected in the hydrosystem during the spring of 2000.

Precociously mature age- 0 or age- 1 parr, although uncommon (especially age- 0 ), were also observed in our study streams. We estimated that 7.5 mature, wild, male parr were present for each anadromous female spawner (i.e., redd) in Catherine Creek during the late summer, and 
early fall of 2001 (Appendix Table A-5). Mature parr were also captured in the Lostine River during the summer of 2001 but we were unable to estimate their population (see Egg-to-Parr Survival, Parr Abundance, and Age Composition in Summer). Precocious male chinook salmon parr are capable of fertilizing eggs and producing viable offspring in a hatchery environment (Robertson 1957, Unwin et al. 1999) and may play an important role in the fertilization of eggs in the wild (Gebhards 1960). However, it is still unclear how much, if any, this life history strategy contributes to the wild population. Therefore, we can conclude only that the potential exists for mature, wild, male parr to make significant gametic contributions. Twenty-one mature, hatchery, male parr in Catherine Creek and two in the Lostine River were either observed or caught while we were catching and marking wild spring chinook salmon parr during summer 2001. These mature, hatchery parr may also spawn with wild adult females. Given the continual low abundance of anadromous spawners in northeast Oregon streams, mature male parr (wild and hatchery) may be an important component of the breeding population.

\section{SUMMER STEELHEAD INVESTIGATIONS}

\section{Methods}

In the Grande Ronde River basin, most steelhead populations are sympatric with rainbow trout populations and only steelhead smolts can be visually differentiated from resident rainbow trout. For this reason, it was necessary to treat all juvenile Oncorhynchus mykiss as one population.

We took two approaches to our study of $O$. mykiss in the Grande Ronde River basin. The first approach involved studying the $O$. mykiss population in Catherine Creek upstream of our screw trap during summer to learn more about the characteristics of this population, including abundance, migration characteristics, growth rates, and population size and age structure. The second approach involved using screw traps to study the movement of juvenile $O$. mykiss downstream from tributary habitats in Catherine Creek, the Lostine, Minam, and upper Grande Ronde rivers. We assumed all juvenile $O$. mykiss captured at trap sites were making directed downstream movements and not localized movements. Violation of this assumption would result in positively biased population estimates

\section{Characterization of the $O$. mykiss Population in Catherine Creek and Tributaries During Summer}

During the summer of 2001, we continued the investigation of $O$. mykiss in the upper Catherine Creek drainage that began in the summer of 2000. We estimated the abundance, age composition, and size structure of the Catherine Creek and North Fork Catherine Creek $O$. mykiss populations in the summer of 2001. We used PIT tags to learn more about migration patterns, anadromy, and growth rates of $O$. mykiss tagged in the summer of 2000 in Catherine Creek, Little Catherine Creek, North Fork Catherine Creek, and the South Fork Catherine Creek. 
Summer Abundance Estimates: Catherine Creek: We used mark-and-recapture techniques to estimate the abundance of $O$. mykiss in the mainstem of Catherine Creek during July 2001. O. mykiss were collected in Catherine Creek from our screw trap site (rkm 32) upstream 20 kilometers to the confluence of the north and south forks of Catherine Creek. We captured, marked, and released fish in Catherine Creek $16-19$ July 2001. We conducted subsequent sampling at randomly selected $0.4 \mathrm{~km}$ sections $23-26$ July 2001 . We fished about $55 \%$ of the stream upstream from the trap during resampling. We attempted to mark a sufficient number of fish so that the $95 \%$ confidence limits would not exceed $25 \%$ of the mean. We collected $O$. mykiss for marking by beach seining, herding them (while snorkeling) into a seine set perpendicular to the stream flow, or by angling. We marked captured O. mykiss with paint or a PIT tag. The same procedures described for spring chinook salmon parr handling and marking were used for $O$. mykiss (see SPRING CHINOOK SALMON INVESTIGATIONS;

Methods). Fish that were less than $55 \mathrm{~mm}$ fork length were not PIT-tagged. We recorded fork lengths and weights, and collected scales for age analysis from a random subsample of fish. All fish were handled and marked at stream temperatures of $15^{\circ} \mathrm{C}$ or less and released in the area of capture on the day they were processed. During resampling we used the same methods to catch fish as described above. We counted the number of marked and unmarked fish and used Chapman's modification of the Petersen estimate (Ricker 1975) to calculate the abundance of $O$. mykiss in Catherine Creek. We obtained 95\% confidence intervals using equation (3.7) in Ricker (1975) and values from Appendix II in Ricker (1975).

North Fork Catherine Creek: Sampling on North Fork Catherine Creek was conducted 26 June through 12 July 2001. The creek was divided into 5 reaches based on valley geomorphology (Table 18). The $O$. mykiss population size was estimated for each reach using methods appropriate to the stream characteristics and the amount of time available for sampling. Abundance estimates for the individual reaches were combined to estimate the total number of O. mykiss in the North Fork. A description of sampling methods and data analysis techniques by reach follows.

\section{$\underline{\text { Reach } 1}$}

The O. mykiss population in reach 1 was estimated using mark-recapture techniques and the data analysis techniques described above for Catherine Creek. O. mykiss were captured and marked $26-28$ June, and captured and examined for marks $2-3$ July.

\section{Reaches 2 and 3}

A modification of Hankin and Reeves (1988) method of estimating fish abundance using calibrated snorkel counts was used for reaches 2 and 3 . We divided the reaches into $61 \mathrm{~m}$ long segments. Segments of $61 \mathrm{~m}$ in length ensured that they were representative of the reach and at least 10 times longer than the average width of the stream. The time required to sample a $61 \mathrm{~m}$ long segment was short enough to allow us to sample many segments per reach. A systematic subsample of segments was snorkeled by a team of two snorkelers independently counting $O$. mykiss. The mean count of the two divers was calculated for each segment snorkeled. A systematic subsample of the snorkeled segments was also depletion sampled. The depletion sampling, using backpack electrofishers, was conducted at least $2 \mathrm{~h}$, but not more than $24 \mathrm{~h}$, after the snorkel counts. During depletion sampling, block nets were set at the upstream and downstream ends of the segment. Two or more passes were made 
with one or two backpack electrofishers in the downstream direction. Equal time and effort was spent on each pass. Fish caught during each pass were kept in separate aerated buckets and processed after all passes were completed. The depletion estimates were calculated using the Zippen method (for equations see Seber and Le Cren 1967; Kohler and Hubert 1999) and were intended to represent the 'true' O. mykiss numbers for each segment. A calibration factor of 2.83 was estimated by dividing the sum of the depletion estimates by the sum of the mean diver counts for the units that were both snorkeled and depleted (Hankin and Reeves 1988). The average mean diver count for all segments snorkeled, but not depletion sampled, was then multiplied by the calibration factor to get a 'corrected' diver count for the segment. The sum of the segment counts (using 'corrected' diver counts for segments that were only snorkeled, and depletion estimates when available) was extrapolated to the total length of the reach to provide a population estimate (equation 1 in Hankin 1986). Variance of the population estimate was calculated using equation 3 in Hankin 1986.

Sampling methods specific to reaches 2 and 3 are tabulated in Table 19. We assumed that diver counts would underestimate $O$. mykiss numbers in a segment, and that depletion estimates would be more accurate and provide a way to calibrate the diver counts. Our depletion estimates were higher than the diver counts, but the $95 \%$ confidence interval of the sum of the depletion estimates was $\pm 55 \%$. However, we used the depletion estimates to adjust the diver counts in lieu of a better calibration method.

\section{Reaches 4 and 5}

We used the stratified sampling design described in Hankin and Reeves (1988) for estimating O. mykiss numbers in reaches 4 and 5. Stream habitat units were classified as riffle, pool, side channel, or complex unit and $O$. mykiss numbers were estimated for each type of habitat. Length of each unit was recorded and width was measured or estimated. Our mean diver counts were often greater than the depletion estimates so we used uncalibrated diver counts, or depletion sampling when snorkeling was not possible, to estimate $O$. mykiss numbers in the sampled units. We did not find a correlation between area and number of fish estimated for each unit, so estimates were extrapolated by habitat unit number and type. The $O$. mykiss population estimate for reach 4 was calculated using mean diver counts for pools and riffles extrapolated to the total number of pools and riffles, respectively. Side channels accounted for $0.25 \%$ of the total area and less than $1 \%$ of the total length of reach 4 . Side channels were not snorkeled or electrofished, and $O$. mykiss numbers were assumed to be 0 . The population estimate for reach 5 was calculated using mean diver counts for pools and complex units, and depletion sampling for riffles and side channels, most of which were too shallow to snorkel. These estimates were extrapolated to the total number of pools, complex units, riffles, and side channels, respectively. Sampling methods specific to reaches 4 and 5 are tabulated in Table 20.

Lengths and Age-Composition of $\boldsymbol{O}$. mykiss in Summer Rearing Areas: Lengths were measured and scale samples were collected from a subsample of $O$. mykiss that were handled during the mark-recapture and depletion sampling on Catherine Creek and North Fork Catherine Creek. Scales were aged as described for juvenile spring chinook salmon (see SPRING CHINOOK SALMON INVESTIGATIONS; Methods; Egg-to-Parr Survival, Parr Abundance, and Age Composition in Summer) and the information used to estimate the age composition of these populations. 
On Catherine Creek, scales were collected for aging from a random subsample of $O$. mykiss that were measured. We assumed the subsample of the aged fish represented the age composition of the total $O$. mykiss population on Catherine Creek. We tested this by performing a Mann-Whitney comparison of ranked lengths of the aged fish and all the O. mykiss measured. We assumed that the size distribution of all the fish measured was representative of the size distribution of the whole population.

On North Fork Catherine Creek, fork lengths were measured when fish were captured during collection for marking and depletion sampling. We assumed these lengths were representative of the population. Scales for age analysis were taken from a subsample of $O$. mykiss that were measured. We tested whether the lengths of the aged fish were representative of all the measured fish by performing a Mann-Whitney comparison of the ranked lengths. This test indicated that the aged fish were not representative of all the fish measured $(\mathrm{P}=0.001)$. Therefore, an age-length key was created and used to extrapolate the age composition of the population (DeVries and Frie 1996).

Growth Rates: Daily growth rates of PIT-tagged $O$. mykiss were calculated by dividing the difference in fork length of recaptured O. mykiss that were tagged in the summer of 2000 by the elapsed time from tagging to recapture. Mean daily growth rates were calculated for each recapture group (fall 2000 screw trap, spring 2001 screw trap, summer 2001).

\section{In-Basin Migration Timing and Abundance}

The migration timing and abundance of migrating O. mykiss in Catherine Creek, the upper Grande Ronde, Lostine, and Minam rivers were determined by operating rotary screw traps year round. We followed the same methodology for operating screw traps and analyzing data as described for spring chinook salmon (see SPRING CHINOOK SALMON INVESTIGATIONS; Methods; In-Basin Migration Timing and Abundance).

The 2001 migratory year for summer steelhead within the Grande Ronde River basin overlaps two calendar years, and begins on 1 July 2000 and ends on 30 June 2001. Similar to spring chinook salmon, there is a distinct early migration that peaks at our trap sites in the fall. Early migrants leave upper rearing areas in Catherine Creek, the upper Grande Ronde, Lostine, and Minam rivers and overwinter in downstream habitat. A proportion of these fish continue their seaward migration out of the basin the following spring. Late migrants exhibit another life history strategy whereby they remain in upper rearing areas throughout fall and winter, and then leave their upper rearing areas in spring to initiate their seaward migration or continue to rear for another year in other areas of the Grande Ronde River basin before initiating their seaward migration. Designations of early and late migratory groups were based on trends in capture rates at trap sites. A common period of diminished capture rates occurs at our trap sites in winter and was used to classify fish into early and late migratory groups. We then determined migrant abundance and migration timing at trap sites by migratory group. 


\section{Migration Timing to Lower Granite Dam}

Detections of PIT-tagged O. mykiss at Lower Granite Dam on the Snake River were used to estimate migration timing. Daily detection counts were expanded to account for fish that may have passed undetected in spill at the dam (see SPRING CHINOOK SALMON

INVESTIGATIONS; Methods; Migration Timing to Lower Granite Dam). The fall 2000 tag group included fish that moved past our upper trap sites between September and early December (early migrants). The spring 2001 tag group included fish that moved past our upper trap sites between February and mid June (late migrants). We intended to tag 1,000 O. mykiss in the fall and 500 in the spring at each of our trap sites on the upper Grande Ronde River, Catherine Creek, and Lostine River, and Minam River to assess migration timing of early and late migrants from each location. During fall, we tagged O. mykiss $\geq 55 \mathrm{~mm}$ FL, whereas during spring, only $O$. mykiss $\geq 115 \mathrm{~mm}$ FL were PIT-tagged. In previous years of this study, $115 \mathrm{~mm}$ FL was the minimum length of $O$. mykiss detected at Snake and Columbia River dams in the same migratory year they were tagged. Fish under $115 \mathrm{~mm}$ FL may not migrate to the dams until the following migratory year. By using this length criterion during spring, we attempted to tag $O$. mykiss that would migrate seaward during 2001. Migration timing was also assessed for fish PIT-tagged at traps during the previous migratory year (i.e. fall 1999 and spring 2000 tag groups) that delayed their migration until MY 2001. Overall migration timing for the Catherine Creek O. mykiss population was determined by examining the detections of fish that were PITtagged during the summer of 2000 on Catherine Creek and its tributaries.

First, last, and median dates of detection at Lower Granite Dam were determined for the fall tagged fish from each location and the summer tagged fish from Catherine Creek and its tributaries. First and last detection dates were determined for the spring tagged fish from each location. Median detection dates for spring tagged fish were reported only if the number tagged was proportional to the number migrating past the trap, as evaluated by the Pearson product moment correlation of the number tagged by week and the number estimated to pass the same week. Otherwise, it was likely that the median reflected, to some extent, the dates of tagging rather than the true migration pattern of all late migrants. We investigated whether detection dates of early and late migrants differed by using the Mann-Whitney rank sum test on dates of detection of fall tagged and spring tagged fish. We only tested this if we determined that the numbers tagged weekly at the trap in the spring were proportional to the numbers moving past the trap.

\section{Detections at Snake and Columbia River Dams}

O. mykiss were PIT-tagged at our upstream screw traps during the fall of 1999 and 2000 and the spring of 2000 and 2001. Dam detections of the PIT-tagged O. mykiss were summarized by tag group, location, and tag year. Detection rates were calculated by dividing the number of tagged $O$. mykiss detected by the number tagged.

During the summer of 2000, we captured and PIT-tagged O. mykiss in their rearing areas on Catherine Creek above the screw trap, South Fork Catherine Creek, North Fork Catherine Creek, and Little Catherine Creek (Monzyk et al. 2000). Detections of these PIT-tagged fish at 
the dams on the Snake and Columbia rivers reflected the prevalence of the anadromous (steelhead) life history pattern in this population and the survival of the juveniles before reaching the dams. However, it was impossible to separate these two components. Detection rates for $O$. mykiss PIT-tagged during the summer of 2001 in their upper rearing areas on Catherine Creek and North Fork Catherine Creek will be presented in the 2002 annual report

\section{Length and Age of Migrants}

We examined the detections of fish tagged in the fall to determine if there was a relationship between size at the time of tagging and tendency to continue their seaward migration the following spring. Within each fall 2000 tag group, t-tests or Mann-Whitney rank sum tests were used to compare lengths of $O$. mykiss detected at the dams in 2001 to the lengths all $O$. mykiss tagged. For O. mykiss tagged in the fall of 1999, a Kruskal-Wallis ANOVA on ranks was used to compare the lengths of those detected at the dams in 2000 and 2001 to all those tagged. The same comparisons were made for O. mykiss tagged in the spring of 2000 and 2001 to determine if there was a relationship between size at the time of tagging and tendency to migrate seaward.

O. mykiss lengths at tagging in the summer of 2000, upstream of the Catherine Creek trap, were compared for fish grouped by their subsequent recapture and dam detection history to determine if there was a relationship between fish size and life history. Lengths were compared (t-test) between O. mykiss that were recaptured at the Catherine Creek screw trap in the fall of 2000 and those recaptured in the spring of 2001 to determine if size was related to the timing (early or late) of migration out of upper rearing areas. Lengths were also compared between $O$. mykiss that were known to migrate out of upstream rearing habitats before the next summer (fall 2000 and spring 2001 trap recaptures and 2001 dam detections), those that stayed upstream through the next summer (all detections at the Catherine Creek screw trap or upstream recaptures during summer 2001 or later), and all the O. mykiss tagged during the summer of 2000 (KruskalWallis ANOVA on ranks and Dunn's pair-wise multiple comparison procedure).

Scale samples taken at the time of tagging allowed us to determine the ages of $O$. mykiss when they migrated past the traps and to extrapolate their age when they were subsequently detected the dams. Scales were analyzed to determine age as described for spring chinook salmon parr (see SPRING CHINOOK SALMON INVESTIGATIONS; Methods; Egg-toParr Survival, Parr Abundance, and Age Composition in Summer).

\section{Results and Discussion}

\section{Characterization of the $O$. mykiss Population in Catherine Creek and Tributaries During Summer}

Summer Abundance Estimates: We estimated that 25,736 (95\% CI: 21,005 - 31,519) O. mykiss were present in Catherine Creek above our screw trap (rkm 32) in July 2001 (Table 
21). This was similar to the summer 2000 estimate of 22,393 (95\% CI: $17,467-28,697)$ fish (Appendix Table B-1).

By combining individual reach results, we estimated that 10,338 (95\% CI: 5,137 15,539) O. mykiss were present in North Fork Catherine Creek in late June/early July of 2001 (Table 21). Estimates by reach indicated that most (86\%) of these fish were in the lower 4.5 kilometers of North Fork Catherine Creek, from the mouth upstream to the confluence of Middle Fork Catherine Creek. O. mykiss abundance decreased with distance upstream, as exhibited by decreasing estimates from reach 1 (downstream) through reach 5 (furthest upstream). O. mykiss were observed as far upstream as rkm 14.6. However, only a few were observed in reach 5.

Length and Age Composition of $\boldsymbol{O}$. mykiss in Summer Rearing Areas: Analysis of scales taken from Catherine Creek O. mykiss indicated the presence of age-1, age-2, and age-3 fish, with age-1 being the most abundant (Figure 16 and Appendix Table B-2). Although none of the scales analyzed were age- 0 , age- 0 fish were presumably present in the population. Sampling occurred in early summer before some of the age- 0 O. mykiss had emerged from the gravel. The length of the smallest fish we aged was $72 \mathrm{~mm}$. However, 13 of the 1,024 fish we measured during our tagging efforts had fork lengths between 45 and $70 \mathrm{~mm}$. It is likely that most of these fish were age- 0 . Snorkel-seining may have resulted in an under representation of the larger size classes and the small, age- 0 fry.

Scale analysis revealed the presence of ages 0-3 O. mykiss in North Fork Catherine Creek (Figure 16 and Appendix Table B-2). As seen in the mainstem, age-1 fish were also most common in the north fork. However, there appeared to be a more even distribution of fish amongst all the age classes in the north fork compared to the mainstem. This may have been a result of bias in our sampling methods. Electroshocking was the primary sampling method used in the north fork, whereas snorkel seining was used in the mainstem. The difference in age structure between North Fork Catherine Creek and the mainstem of Catherine Creek could also reflect a relatively higher abundance or resident $O$. mykiss in the north fork compared to the mainstem.

The length distributions of $O$. mykiss reflected the age compositions in Catherine Creek and the North Fork Catherine Creek (Figure 17). The median fork length of O. mykiss sampled in Catherine Creek was $111 \mathrm{~mm}$, and in North Fork Catherine Creek was $102 \mathrm{~mm}$.

Growth Rates: The mean daily growth rate of $O$. mykiss tagged upstream of the Catherine Creek trap in the summer of 2000 and recaptured at the Catherine Creek screw trap in the fall of 2000 was $0.173 \mathrm{~mm} / \mathrm{d}$ (Table 22). Growth rates for $O$. mykiss recaptured in the spring and summer 2001 were lower because the time between length measurements included the winter period when growth would have been minimal.

\section{In-Basin Migration Timing and Abundance}

Distinct early and late migrations were evident at most of our upper trap sites with few fish captured during winter months (Figure 18). For the purpose of this report, early migration 
was considered to encompass the time from 1 July 2000 through 28 January 2001 and late migration from 29 January through 30 June 2001.

Upper Grande Ronde River: The upper Grande Ronde River trap fished for $183 \mathrm{~d}$ from 1 July through ice-up on 11 November 2000, and from 18 March through 30 June 2001 (Table 23). A distinct early migration was not as evident at this trap site as it was at other upper trap sites (Figure 18). Most juvenile O. mykiss moved as late migrants during spring months. The median emigration date for early migrants passing the trap was 11 October 2000 and the median emigration date for late migrants was 07 May 2001. The median migration date for late migrants in MY 2001 was later than in previous years of this study (Table 24).

We estimated a minimum of 16,067 juvenile O. mykiss $(95 \% \mathrm{CI}: \pm 4,076)$ moved out of the upper Grande Ronde River upper rearing areas during MY 2001. This estimate is within estimates from the previous three migratory years study that ranged from 6,108 (MY 1999) to 17,845 fish (MY 2000). Based on weekly trap efficiencies, we estimated approximately 4\% (607 $\pm 84)$ were early migrants and $96 \%(15,460 \pm 4,075)$ were late migrants. The pattern of a dominant late migration of juvenile $O$. mykiss in the upper Grande Ronde River is consistent for all migratory years studied to date (Table 24). In previous years, the proportion of late migrants has ranges from 60\% (MY 1998) to 95\% (MY 1999).

Catherine Creek: The Catherine Creek trap fished for $235 \mathrm{~d}$ from 1 July through ice-up on 6 December 2000, and from 20 February through 30 June 2001 (Table 23). There were distinct early and late migrations exhibited by juvenile $O$. mykiss at this trap site (Figure 18). Median emigration date for early migrants was 06 October 2000 . The median date for late migrants was 31 March 2001 (Table 24).

We estimated that a minimum of 20,586 $\pm 4,336$ juvenile $O$. mykiss migrated out of the Catherine Creek upper rearing areas during MY 2001. This estimate is within the range of estimates from previous years of this study (Table 24). Based on weekly trap efficiencies, $44 \%$ $(8,957 \pm 938)$ migrated early and $56 \%(11,629 \pm 4,233)$ migrated late. The proportion of juvenile $O$. mykiss leaving upper rearing areas as late migrants is only slightly less than proportions from previous years of this study that range from 58 to $75 \%$ (Table 24). The Catherine Creek population appears to be different from the upper Grande Ronde population in that a greater proportion of the overall migrant population tends to leave upper rearing areas before the onset of winter.

Grande Ronde Valley: The Grande Ronde Valley trap fished for $162 \mathrm{~d}$ from 4 October 2000 through 12 January 2001, and 1 February through 20 June 2001 (Table 23). A distinct late migration was evident with few fish passing the trap as early migrants (Figure 18). The median emigration date for fish passing the trap as early migrants was 17 November 2000. The median emigration date for late migrants was 25 April 2001.

We estimated a minimum of $46,470 \pm 8,425$ juvenile $O$. mykiss migrated out of the Grande Ronde Valley during MY 2001. This estimate is within the range of estimates from previous years of this study. In previous years, estimates have ranged from 46,084 (MY 1997) to 60,266 (MY 2000). However, there were numerous trap stoppages during the peak migration 
period due to debris blockage and mechanical breakdowns, therefore, we most likely underestimated the number of steelhead out-migrating this year. We estimated $235 \pm 54$ juvenile O. mykiss passed the trap as early migrants and 46,235 $\pm 8,425$ O. mykiss passed the trap as late migrants. As in past years, late migrants dominate the catch at this trap. These data indicate that most juvenile $O$. mykiss that left the upper rearing areas during fall overwintered in the valley reaches of the Grande Ronde River. Protection and enhancement of habitat in the Grande Ronde Valley should be given high priority to maintain or enhance overwinter survival of juvenile $O$. mykiss that reside in the valley during winter.

Lostine River: The Lostine River trap fished for a total of 323 d from 1 July 2000 through 30 June 2001 (Table 23). Distinct early and late migrations were evident (Figure 18), with few fish captured during summer and winter. The median emigration date of early migrants was 4 October 2000. The date that the median late migrant moved past the trap was 29 April 2001 (Table 24).

We estimated that a minimum of $16,690 \pm 3,541$ O. mykiss migrants moved out of the Lostine River during MY 2001. We estimated that approximately $45 \%(7,514 \pm 1,199)$ of the juvenile $O$. mykiss migrated early and $55 \%(9,176 \pm 3,332)$ migrated late. This is a slightly higher percentage than in previous years of this study where the previous maximum proportion of late migrants was $46 \%$ in MY 1998 (Table 24).

Minam River: The Minam River trap fished for $139 \mathrm{~d}$ between 27 September through 16 November 2000, and 22 February through 18 June 2001 (Table 23). There were distinct early and late migrations exhibited by juvenile $O$. mykiss at this trap site (Figure 18). Median emigration date for early migrants was 3 October 2000 . The median date for late migrants was 29 April 2001 (Table 24).

We estimated that a minimum of $28,113 \pm 11,052$ juvenile $O$. mykiss migrated out of the Minam River during MY 2001. Based on weekly trap efficiencies, 14\% (3,906 $\pm 6,568)$ migrated early and $86 \%(24,207 \pm 8,889)$ migrated late. The migrant estimate may not be accurate. More early migrants may have moved past our trap than reported here because the trap was not started until late September, thereby potentially missing some of the early migration.

\section{Migration Timing to Lower Granite Dam}

Upper Grande Ronde River: During MY 2001, we PIT-tagged 61 early- and 475 latemigrating $O$. mykiss at the upper Grande Ronde River trap that were not previously tagged. The median migration date to Lower Granite Dam for the early migrants was 7 May (Figure 19). The first detection was 28 April and the last was 29 June. The late migrants were detected between 22 April and 11 June. A median detection date was not determined because numbers of $O$. mykiss tagged in the spring (by week) were not proportional to the numbers migrating past the trap (Pearson product moment correlation, $P=0.237$ ). Travel times from the screw trap to Lower Granite Dam for late migrating O. mykiss ranged from 8 to $152 \mathrm{~d}$ with a mean of $37.1 \mathrm{~d}(n$ $=180)($ Table 25 and Appendix Table B-3). 
Catherine Creek: During MY 2001, we PIT-tagged 561 early- and 266 late-migrating O. mykiss at the Catherine Creek trap. The median migration date for the early migrants was 6 May (Figure 20). The first detection was 18 April and the last was 12 June. The late migrants were detected between 22 April and 11 June, with a median detection date of 14 May. The median detection date for early migrants was significantly earlier than the median for late migrants (Mann-Whitney rank sum test, $P=0.002$; Appendix Table B-4). Travel times from the screw trap to Lower Granite Dam for late migrating O. mykiss ranged from 7 to $74 \mathrm{~d}$ with a mean of $33.0 \mathrm{~d}(n=88)$ (Table 25 and Appendix Table B-3).

Detections of summer tagged $O$. mykiss represented the migration timing of the overall (early and late migrants) Catherine Creek population past Lower Granite Dam. The median date of migration past Lower Granite Dam for O. mykiss PIT-tagged during the summer of 2000 on Catherine Creek and its tributaries (including the north and south forks, and Little Catherine Creek) was 8 May (Figure 21 and Appendix Table B-5). Tagged O. mykiss from these locations were detected at Lower Granite Dam between 25 April and 25 June.

Lostine River: At the Lostine River trap, we PIT-tagged 421 early- and 345 latemigrating $O$. mykiss that were not previously tagged. The median migration date for the early migrants was 12 May (Figure 22). The first detection was 16 April and the last was 13 June. The late migrants were detected between 13 April and 18 August, with a median detection date of 14 May. The median detection dates for early and late migrants were not significantly different for Lostine River $O$. mykiss smolts (Mann-Whitney rank sum test, $P=0.829$ ). However, the power of this test was low given the small sample sizes for early migrants $(n=13)$. Travel times from the screw trap to Lower Granite Dam for late migrating O. mykiss ranged from 5 to $109 \mathrm{~d}$ with a mean of $17.6 \mathrm{~d}(n=164)$ (Table 25 and Appendix Table B-3).

Minam River: At the Minam River trap, we PIT-tagged 32 early- and 454 latemigrating $O$. mykiss that were not previously tagged. The median migration date for the early migrants was 9 May (Figure 23). The first detection was 2 May and the last was 17 May. The late migrants were detected between 26 April and 29 August, with a median detection date of 7 May. The median detection dates for early and late migrants were not significantly different (Mann-Whitney rank sum test, $P=0.624$ ). However, the power of this tests was low given the small sample sizes for early migrants $(n=6)$. Travel times from the screw trap to Lower Granite Dam for late migrating $O$. mykiss ranged from 5 to $110 \mathrm{~d}$ with a mean of $21.8 \mathrm{~d}(n=240)$ (Table 25 and Appendix Table B-3).

Smolt Timing of $O$. mykiss Tagged During MY 2000: Some $O$. mykiss tagged at the upstream traps in MY 2000 as they migrated out of upper rearing areas were detected at Lower Granite Dam in 2001. These fish arrived at Lower Granite Dam slightly earlier than fish tagged in MY 2001. The O. mykiss tagged in MY 2000 from the upper Grande Ronde River were detected between 30 April and 6 June, with a median date of 3 May ( $n=7$, Appendix Table B-6). Those from Catherine Creek were detected between 2 April and 26 May, with a median migration date of 4 May $(n=25)$. Those from the Lostine River were detected between 27 April and 7 June, with a median date of 4 May $(n=22)$. 


\section{Detections at Snake and Columbia River Dams}

Detection rates of $O$. mykiss tagged in fall 2000 ranged from 0.040 for Lostine River fish to 0.219 for Minam River fish (Table 26 and Appendix Table B-7). Some O. mykiss migrants tagged at the screw traps in the fall of 1999 did not migrate past the dams until the following migratory year. For example, 14 O. mykiss PIT-tagged at the Catherine Creek trap and 11 tagged at the Lostine trap during the fall of 1999 were detected at the dams in 2001 migratory year (Table 26 and Appendix Table B-7).

Detection rates of $O$. mykiss tagged in the spring 2001 ( $\geq 115 \mathrm{~mm}$ FL) ranged from 0.389 for Catherine Creek fish to 0.609 for Minam River fish (Table 27 and Appendix Table B-7). Some $O$. mykiss tagged at the screw traps in the spring of 2000 did not migrate past the dams until the following migratory year. For example, 12 O. mykiss that were PIT-tagged at the Catherine Creek trap, 7 tagged at the upper Grande Ronde trap, and 14 tagged at the Lostine trap during the spring of 2000 were not detected at the dams until the 2001 migratory year (Appendix Table B-7).

It was not possible to distinguish between steelhead and resident rainbow parr in their summer rearing habitat. For this reason, dam detections of O. mykiss parr PIT-tagged in the summer reflected not just survival to the dam detection sites but also the prevalence of the anadromous life history pattern. A small percentage $(2.5 \%)$ of wild $O$. mykiss PIT-tagged in Catherine Creek and its tributaries during the summer of 2000 were detected at Snake and Columbia River dams as they migrated seaward (Table 28). Some O. mykiss tagged in the summer of 2000 may migrate seaward in 2002 or 2003 . Detections of these fish, if any, will be reported in future annual reports.

\section{Length and Age of Migrants}

Fork lengths at time of tagging were compared between $O$. mykiss detected at the dams in 2001 and all O. mykiss tagged for the various tag groups (Appendix Tables B-5 and B-6). Of all the $O$. mykiss tagged at the traps in the fall of 2000, the larger individuals from the upper Grande Ronde and Lostine rivers tended to be the ones detected at the dams in 2001 (Figure 24). The mean fork length of the $O$. mykiss tagged in the fall of 2000 at the upper Grande Ronde River trap and then detected at the dams in $2001(148.3 \mathrm{~mm})$ was greater than the mean length of all those tagged on the upper Grande Ronde River in the fall of $2000(125.5 \mathrm{~mm}, P=0.005)$. The median length of the $O$. mykiss tagged in the fall of 2000 at the Lostine River trap and detected at the dams in $2001(161 \mathrm{~mm})$ was greater than the median of all those tagged on the Lostine River in the fall of $2000(80 \mathrm{~mm}, P<0.001)$. There was no difference in lengths of fish detected at the dams compared to all fish tagged in the fall of 2000 on Catherine Creek and the Minam River. The median length of the O. mykiss tagged at the Catherine Creek trap in the fall of 2000 and detected in $2001(139 \mathrm{~mm})$ did not differ from the median of all those in the same tag group (136 $\mathrm{mm}, P=0.298$ ). The mean length of the $O$. mykiss tagged at the Minam River trap in the fall of 2000 and detected in $2001(143.1 \mathrm{~mm})$ did not differ from the mean of all those in the same tag group (116.1 mm, $P=0.157$ ), however the power of the test was low due to a small sample size. 
As with upper Grande Ronde River and Lostine River O. mykiss tagged in the fall of 2000, the larger individuals tagged at the traps in the spring of 2001 tended to be the ones detected at the dams in 2001 (Figure 25). The mean lengths of the O. mykiss tagged at the Catherine Creek and Minam River traps in the spring of 2001 and detected in 2001 (149.7 mm and $166.9 \mathrm{~mm}$, respectively) differed significantly from the means of the tag groups $(140.0 \mathrm{~mm}$, $159.7 \mathrm{~mm}$ respectively, $P<0.001$ ). The median lengths of the $O$. mykiss tagged at the upper Grande Ronde River and Lostine River traps in the spring of 2001 and detected in 2001 (156 mm and $171 \mathrm{~mm}$, respectively) differed significantly from the medians of the tag groups (146 mm and $160 \mathrm{~mm}$, respectively, $P<0.001)$.

While some of the differences in length between all tagged fish and those detected at dams could be the result of size-dependent mortality, there is evidence that smaller individuals passing the traps delay their migration until the subsequent migratory year. For instance, the $O$. mykiss migrants that were tagged at screw traps in the fall of 1999 and delayed their migration until the 2001 migratory year were generally smaller than the other fish in that tag group (Figure 26). The median lengths (at tagging) of O. mykiss tagged at traps on Catherine Creek and the Lostine River in the fall of 1999 and detected at the dams in $2001(77 \mathrm{~mm}$ and $105 \mathrm{~mm}$, respectively; Appendix Table B-8) were significantly less than the medians of all those tagged (101 $\mathrm{mm}$ and $153 \mathrm{~mm}$, respectively) and the medians of those detected in 2000 (148 $\mathrm{mm}$ and 157 mm, respectively) for each location $(P<0.001)$.

Similarly, the $O$. mykiss migrants that were tagged at screw traps in the spring of 2000 and delayed their migration until the 2001 migratory year were generally smaller than the other fish in that tag group (Figure 27). The median lengths of O. mykiss tagged in the spring of 2000 at Catherine Creek, upper Grande Ronde River, and the Lostine River traps and later detected at the dams in 2001 (78.5 mm, $80 \mathrm{~mm}$, and $89 \mathrm{~mm}$, respectively; Appendix Table B-9) were significantly less than the medians of all those tagged in that tag group $(131.5 \mathrm{~mm}, 133 \mathrm{~mm}$, and $160 \mathrm{~mm}$, respectively) and the medians of that tag group detected in $2000(152 \mathrm{~mm}, 155 \mathrm{~mm}$, and $168 \mathrm{~mm}$, respectively) for each location $(P<0.001)$.

Trap recaptures and dam detections suggested that, of the $O$. mykiss PIT-tagged during the summer of 2000 upstream of the Catherine Creek trap, the larger ones were more likely to migrate out of the upstream rearing areas within the subsequent year. The median length (at tagging) of $O$. mykiss that migrated out of the upper rearing area by early summer 2001 was greater than the median length of all those tagged during the summer of 2001 on Catherine Creek and the median length of those known to remain upstream of the Catherine Creek screw trap through the summer of $2001(P=0.001$, Figure 28). As mentioned above, this pattern could also reflect size dependent mortality. Limited trap recaptures of $O$. mykiss PIT-tagged in the summer of 2000 did not reveal a relationship between length (at tagging) and tendency to migrate out of upper rearing in the fall of 2000 (early migrants) as opposed to the spring of 2001 (late migrants, $P=0.994$, Figure 29 and Appendix Table B-10). However, small sample sizes resulted in low power $(0.05)$ to detect a difference.

The $O$. mykiss collected at traps during the 2001 migratory year ranged from 0 to 3 years of age (Table 29). Most early migrants were age- 1 with few age- 0 or age- 2 migrants passing the trap. These age- 1 migrants would presumably resume their seaward migration (and be detected 
at downstream dams) the following spring as age- 2 smolts. The proportion of age- 2 migrants was greater during the late migration period, but never reached over $50 \%$ of the total late migrant population (Table 29). The majority of late migrants were again age-1 fish. Of the fish with known age that were PIT-tagged at the traps in MY 2001 and subsequently detected at Snake and Columbia River dams $(n=46)$, most $(91 \%)$ reached the dams as age-2 smolts while four $(9 \%)$ were age-3. No age-1 smolts were detected. Of the five fish with known age tagged in the fall of 1999 and not detected at the dams until the 2001 migratory year, two were age- 0 and three were age-1. These fish were age- 2 and age- 3 when detected at the dams in 2001.

The results of the length and age analyses indicate that most of the smaller individuals (age-0 early migrants and age-1 late migrants) that passed the trap sites tended to rear for another year before undertaking their seaward migration. The larger individuals (age- 1 or age- 2 early migrants and age- 2 or age-3 late migrants) that passed the trap sites tended to undertake their seaward migration during the same migratory year.

\section{FUTURE DIRECTIONS}

We will continue this early life history study of spring chinook and summer steelhead in Catherine Creek and the upper Grande Ronde, Lostine, and Minam rivers. As we obtain more information on age-specific fecundities of wild spring chinook salmon and age structure of spawning populations, we will improve our estimates of egg-to-parr and egg-to-smolt survival.

\section{REFERENCES}

Beckman, B. R., D. A. Larsen, B. Lee-Pawlak, and W. W. Dickhoff. 1998. Relation of fish size and growth rate to migration of spring chinook salmon smolts. North American Journal of Fisheries Management 18: 537-546.

Bryson, D. 1993. Northeast Oregon Hatchery Grande Ronde River Management Plan. Final Report. Bonneville Power Administration, Portland, OR.

Burck, W. A. 1967. Mature stream-reared spring chinook salmon. Oregon Fish Commission Research Briefs 13(1): 128.

Burck, W. A. 1993. Life history of spring chinook salmon in Lookingglass Creek, Oregon. Oregon Department of Fish and Wildlife, Information Reports 94-1, Portland.

DeVries, D. R., and R. V. Frie. 1996. Determination of age and growth. Pages 483-512 in B. R. Murphy and D. W. Willis, editors. Fisheries techniques, 2nd edition. American Fisheries Society, Bethesda, MD.

Efron, B., and R. Tibshirani. 1986. Bootstrap methods for standard errors, confidence intervals, and other measures of statistical accuracy. Statistical Science 1: 54-77. 
Ewing, R. D., C. E. Hart, C.A. Fustish, and G. Concannon. 1984. Effects of size and time of release on seaward migration of spring chinook (Oncorhynchus tshawytscha). Fishery Bulletin 82: 157-164.

Gebhards, S. V. 1960. Biological notes on precocious male chinook salmon in Salmon River drainage. Progressive Fish-Culturist 22(3): 121-123.

Giorgi, A. E., G. A. Swan, W. S. Zaugg, T. C. Corley and T. Y. Barila. 1988. The susceptibility of chinook salmon smolts to bypass systems at hydroelectric dams. North American Journal of Fisheries Management 8:25-29.

Hankin, D. G. 1986. Sampling designs for estimating the total number of fish in small streams. Pacific Northwest Research Station, Research Paper PNW-360.

Hankin, D. G., and G. H. Reeves. 1988. Estimating total fish abundance and total habitat area in small streams based on visual estimation methods. Canadian Journal of Fisheries and Aquatic Science 45:834-844.

Hart, P. J. B., and T. J. Pitcher. 1969. Field trials of fish marking using a jet inoculator. Journal of Fish Biology 1: 383-385.

Irvine, J. R. and B. R. Ward. 1989. Patterns of timing and size of wild coho salmon (Oncorhynchus kisutch) smolts migrating from the Keogh River watershed on northern Vancouver Island. Canadian Journal of Fish and Aquatic Science 46: 1086-1094.

Johnson, G. E., R. L. Johnson, E. Kucera, C. Sullivan. 1997. Fixed-location hydroacoustic evaluation of the prototype surface bypass and collector at Lower Granite Dam in 1996. Final Report. U.S. Army Corps of Engineers, Walla Walla, WA.

Jonasson, B. C., R. W. Carmichael, and M. Keefe. 1996. Investigations into the early life history of naturally produced spring chinook salmon in the Grande Ronde River basin. Annual Progress Report. Bonneville Power Administration, Portland, OR.

Jonasson, B. C., J. V. Tranquilli, M. Keefe, and R. W. Carmichael. 1997. Investigations into the early life history of naturally produced spring chinook salmon in the Grande Ronde River basin. Annual Progress Report. Bonneville Power Administration, Portland, OR.

Jonasson, B. C., J. V. Tranquilli, P. M. Sankovich, E. Van Dyke, M. Keefe, and R. W. Carmichael. 1999. Investigations into the early life history of naturally produced spring chinook salmon in the Grande Ronde River basin. Annual Progress Report. Bonneville Power Administration, Portland, OR.

Keefe, M., D. J. Anderson, R. W. Carmichael, and B. C. Jonasson. 1995. Early life history study of Grande Ronde River basin chinook salmon. Annual Progress Report. Bonneville Power Administration, Portland, OR. 
Keefe, M., R. W. Carmichael, B. C. Jonasson, R. T. Messmer, and T. A. Whitesel. 1994. Investigations into the life history of spring chinook salmon in the Grande Ronde River basin. Annual Progress Report. Bonneville Power Administration, Portland, OR.

Kohler, C. C., and W. A. Hubert, editors. 1999. Inland fisheries management in North America, 2nd edition. American Fisheries Society, Bethesda, MD.

Kuehl, S. 1986. Hydroacoustic evaluation of fish collection efficiency at Lower Granite Dam in spring 1985. Final Report to U.S. Army Corps of Engineers, Walla Walla, WA.

Lady, J, P. Westhagen, J. R. Skalski. 2001. SURPH.2 User Manual, SURPH 2.1, SURvival under Proportional Hazards. School of Aquatic and Fisheries Sciences, University of Washington, Seattle, WA. http://www.cqs.washington.edu/paramEst/SURPH

Matthews, G. M., J. R. Harmon, S. Achord, O. W. Johnson, and L. A. Kubin. 1990. Evaluation of transportation of juvenile salmonids and related research on the Columbia and Snake rivers, 1989. Report of the U.S. Army Corps of Engineers, Contract DACW68-84H0034. National Marine Fisheries Service, Seattle.

Matthews, G. M., and eight coauthors. 1992. Evaluation of transportation of juvenile salmonids and related research on the Columbia and Snake rivers, 1990. Report of the U.S. Army Corps of Engineers, Contract DACW68-84-H0034. National Marine Fisheries Service, Seattle.

Monzyk, F. M., B. C. Jonasson, E. Van Dyke, A. G. Reischauer, and R. W. Carmichael. 2000. Investigations into the early life history of naturally produced spring chinook salmon and summer steelhead in the Grande Ronde River basin. Annual Progress Report. Bonneville Power Administration, Portland, OR.

Northcote, T. G., and D. W. Wilkie. 1963. Underwater census of stream fish populations. Transactions of the American Fisheries Society 92: 146-151.

NWPPC (Northwest Power Planning Council). 1992. Strategy for salmon, Volume VII.

ODFW (Oregon Department of Fish and Wildlife). 1990. Grande Ronde River Subbasin Salmon and Steelhead Production Plan. Oregon Department of Fish and Wildlife, Portland, OR.

Prentice, E. F., T. A. Flagg, C. S. McCutcheon, D. F. Brastow, and D. C. Cross. 1990. Equipment, methods, and an automated data-entry station for PIT tagging. American Fisheries Society Symposium 7: 335-340.

Prentice, E. F, D. L. Park, T. A. Flagg, and S. McCutcheon. 1986. A study to determine the biological feasibility of a new fish tagging system, 1985-1986. Annual Progress Report. Bonneville Power Administration, Portland OR. 
Ricker, W. E. 1972. Heredity and environmental factors affecting certain salmonid populations. Pages 19-160 in R.C. Simon and P.A. Larkin, editors. The stock concept in Pacific salmon. H. R. MacMillan lectures in fisheries, University of British Columbia, Vancouver.

Ricker, W. E. 1975. Computation and interpretation of biological statistics of fish populations. Fisheries Research Board of Canada Bulletin 191.

Robertson, O. H. 1957. Survival of precociously mature king salmon male parr (Oncorhynchus tshawytscha, juv.) after spawning. California Fish and Game 43 (2): 119-130.

Rohlf, F. J. and R. R. Sokal. 1995. Statistical Tables, 3rd edition. W. H. Freeman and Company, New York.

Sankovich, P., R. W. Carmichael, and M. Keefe. 1995. Smolt migration characteristics and mainstem Snake and Columbia River detection rates of Grande Ronde and Imnaha River naturally produced spring chinook salmon. Annual Progress Report. Bonneville Power Administration, Portland, OR.

Sankovich, P. M., R. W. Carmichael, and M. Keefe. 1996. Smolt migration characteristics and mainstem Snake and Columbia river detection rates of PIT-tagged Grande Ronde and Imnaha river naturally produced spring chinook salmon. Annual Progress Report. Oregon Department of Fish and Wildlife, Portland, OR.

Scrivener, J. C., T. G. Brown, and B. C. Andersen. 1994. Juvenile chinook salmon (Oncorhynchus tshawytscha) utilization of Hawks Creek, a small and nonnatal tributary of the upper Fraser River. Canadian Journal of Fish and Aquatic Science 51: 1139-1146.

Seber, G. A. F. and E. D. Le Cren. 1967. Estimating population parameters from catches large relative to the population. Journal of Animal Ecology 36: 631-643.

Snake River Recovery Team. 1993. Draft Snake River salmon recovery plan recommendations. National Marine Fisheries Service, Portland, OR.

Sokal, R. R., and F. J. Rohlf. 1995. Biometry, 3rd edition. W. H. Freeman and Company, New York.

SPSS Inc. 1992-1997. SigmaStat for Windows Version 2.03.

Swan, G. A., R. F. Krcma, and F. J. Ossiander. 1986. Continuing studies to improve and evaluate juvenile collection at Lower Granite Dam, 1985. Report to U. S. Army Corps of Engineers, Portland, OR.

Thedinga, J. F., M. L. Murphy, S. W. Johnson, J. M. Lorenz, and K. V. Koski. 1994. Determination of salmonid smolt yield with rotary-screw traps in the Situk River, Alaska, 
to predict effects of glacial flooding. North American Journal of Fisheries Management 14: 837-851.

Tranquilli, J. V., P. Sankovich, E. Van Dyke, B. C. Jonasson, M. Keefe, and R. W. Carmichael. 1998. Investigations into the early life history of naturally produced spring chinook salmon in the Grande Ronde River basin. Annual Progress Report. Bonneville Power Administration, Portland, OR.

Unwin, M. J., M. T. Kinnison, and T. P. Quinn. 1999. Exceptions to semelparity: postmaturation survival, morphology, and energetics of male chinook salmon (Oncorhynchus tshawytscha). Canadian Journal of Fish and Aquatic Science 56: 11721181.

USACE (United States Army Corps of Engineers). 1975. Lower Snake River Fish and Wildlife Compensation Plan Special Report. U. S. Army Corps of Engineers, Walla Walla, WA.

USFS (United States Forest Service) and six coauthor agencies. 1992. Upper Grande Ronde River Anadromous Fish Habitat Restoration and Monitoring Plan. U. S. Forest Service, Wallowa-Whitman National Forest, Baker, OR.

Walters, T. R., R. W. Carmichael, and M. Keefe. 1992. Smolt migration characteristics and parr-to-smolt survival of naturally produced spring chinook salmon in the Grande Ronde and Imnaha river subbasins. Annual Progress Report, Oregon Department of Fish and Wildlife, Portland, OR.

Walters, T. R., R. W. Carmichael, and M. Keefe. 1993. Smolt migration characteristics and mainstem Snake and Columbia River detection rates of Grande Ronde and Imnaha River naturally produced spring chinook salmon. Annual Progress Report, Oregon Department of Fish and Wildlife, Portland, OR.

Walters, T. R., R. W. Carmichael, and M. Keefe. 1994. Smolt migration characteristics and mainstem Snake and Columbia river detection rates of PIT-tagged Grande Ronde and Imnaha river naturally produced spring chinook salmon. Annual Progress Report. Oregon Department of Fish and Wildlife, Portland, OR.

Walters, T. R., R. W. Carmichael, M. Keefe, and P. Sankovich. 1997. Smolt migration characteristics and mainstem Snake and Columbia River detection rates of Grande Ronde and Imnaha River naturally produced spring chinook salmon. Annual Progress Report 1993, 1994, and 1995. Bonneville Power Administration, Portland, OR.

Zar, J. H. 1984. Biostatistical analysis, 2nd edition. Prentice-Hall, Inc., Englewood Cliffs, New Jersey. 
Table 1. Dates of tagging and number of spring chinook salmon parr PIT-tagged on various northeast Oregon streams during the summers of 2000 and 2001.

\begin{tabular}{lccc}
\hline Year, stream & $\begin{array}{c}\text { Dates of collection and } \\
\text { tagging }\end{array}$ & $\begin{array}{c}\text { Number PIT-tagged } \\
\text { and released }\end{array}$ & $\begin{array}{c}\text { Distance to Lower } \\
\text { Granite Dam }(\mathrm{km})\end{array}$ \\
\hline 2000 & & & \\
Catherine Creek & $7-10$ Aug & 500 & $370-377$ \\
Lostine River & $14-17$ Aug & 490 & $276-290$ \\
Minam River & 22 Aug, 18-19 Sep & 1,000 & $282-283$ \\
Imnaha River & $2-30$ Aug & 1,050 & $222-243$ \\
& & & \\
2001 & & & $363-382$ \\
Catherine Creek & 30 Jul -2 Aug & 503 & $275-301$ \\
Lostine River & $6-9$ Aug & 501 & $282-284$ \\
Minam River & $20-23$ Aug & 996 & $208-240$ \\
Imnaha River & $27-28$ Aug & 1,001 & \\
\hline
\end{tabular}

Table 2. Results from spring chinook salmon mark-and-recapture experiments conducted in Catherine Creek and the Lostine River in August 2001.

\begin{tabular}{ccccc}
\hline Stream, group & $\begin{array}{c}\text { Number } \\
\text { marked (M) }\end{array}$ & $\begin{array}{c}\text { Number } \\
\text { sampled (C) }\end{array}$ & $\begin{array}{c}\text { Number } \\
\text { recaptured (R) }\end{array}$ & $\begin{array}{c}\text { Population estimate (N) } \\
(95 \% \mathrm{CI})\end{array}$ \\
\hline $\begin{array}{c}\text { Catherine Creek } \\
\text { immature } \\
\text { mature }\end{array}$ & 1,325 & 1,382 & 121 & $15,032(12,598-17,931)$ \\
& 111 & 87 & 9 & $986(545-1,971)$ \\
$\begin{array}{c}\text { Lostine River } \\
\text { immature } \\
\text { mature }\end{array}$ & 1,074 & 1,938 & & \\
\hline
\end{tabular}

Table 3. Percent of spring chinook salmon parr population and parr density in Catherine Creek by reach in August 2001.

\begin{tabular}{cccc}
\hline Reach & Length $(\mathrm{km})$ & Percent of total parr population & Density $(\mathrm{parr} / \mathrm{km})$ \\
\hline & & & \\
1 & 5.6 & 25 & 755 \\
2 & 6.2 & 40 & 1,089 \\
3 & 3.5 & 22 & 1,057 \\
4 & 4.5 & 13 & 484 \\
\hline
\end{tabular}


Table 4. Age composition of immature and mature spring chinook salmon parr sampled in Catherine Creek and the Lostine, Minam, and Imnaha rivers in summer 2001. Age was determined by scale analysis.

\begin{tabular}{|c|c|c|c|}
\hline Stream, group & $\begin{array}{c}\text { Number of } \\
\text { parr sampled }\end{array}$ & $\begin{array}{c}\text { Percent age- } 0 \\
(95 \% \mathrm{CI}) \\
\end{array}$ & $\begin{array}{c}\text { Percent age-1 } \\
(95 \% \mathrm{CI}) \\
\end{array}$ \\
\hline $\begin{array}{c}\text { Catherine Creek } \\
\text { Immature }\end{array}$ & $0^{\mathrm{a}}$ & - & - \\
\hline Mature & 103 & $0(0-3.5)$ & $100(96.5-100)$ \\
\hline $\begin{array}{c}\text { Lostine River } \\
\text { Immature } \\
\text { Mature }\end{array}$ & $\begin{array}{l}0^{\mathrm{a}} \\
4\end{array}$ & $-\overline{25.0}(0.6-80.6)$ & $\overline{75.0}(19.4-99.4)$ \\
\hline $\begin{array}{c}\text { Imnaha River } \\
\text { Immature } \\
\text { Mature }\end{array}$ & $\begin{array}{r}67 \\
0^{\mathrm{b}}\end{array}$ & $100(94.6-100)$ & $\begin{array}{l}0(0-5.4) \\
-\end{array}$ \\
\hline $\begin{array}{c}\text { Minam River } \\
\text { Immature } \\
\text { Mature }\end{array}$ & $\begin{array}{r}212 \\
4\end{array}$ & $\begin{array}{c}100(98.3-100) \\
0(0-60.2)\end{array}$ & $\begin{array}{c}0(0-1.7) \\
100(39.8-100)\end{array}$ \\
\hline
\end{tabular}

${ }^{a}$ Scales were not taken. We assumed that all immature parr were age-0.

${ }^{\mathrm{b}}$ Mature parr were rarely observed and none were caught. 
Table 5. Estimated abundance of age- 0 spring chinook salmon parr during the summer, and the corresponding egg-to-parr survival of spring chinook salmon in Catherine Creek and the Lostine River for the 1997-2000 brood years.

\begin{tabular}{|c|c|c|c|c|c|c|c|}
\hline \multirow[b]{2}{*}{$\begin{array}{l}\text { Stream, } \\
\text { brood year }\end{array}$} & \multirow[b]{2}{*}{ Redds $^{\mathrm{a}}$} & \multirow[b]{2}{*}{ Fecundity ${ }^{b}$} & \multirow[b]{2}{*}{$\begin{array}{l}\text { Total } \\
\text { eggs }\end{array}$} & \multicolumn{2}{|c|}{$\begin{array}{l}\text { Age-0 parr in } \\
\text { summer }\end{array}$} & \multicolumn{2}{|c|}{$\begin{array}{l}\text { Egg to age-0 } \\
\text { parr survival }\end{array}$} \\
\hline & & & & immature & mature & $\begin{array}{l}\text { Rate } \\
(\%)\end{array}$ & $95 \% \mathrm{CI}$ \\
\hline \multicolumn{8}{|c|}{ Catherine Creek } \\
\hline 1997 & 46 & 4,348 & 200,008 & 13,222 & 0 & 6.61 & $(5.02-8.91)$ \\
\hline 1998 & 34 & 4,348 & 147,832 & 22,505 & 3 & 15.23 & $(11.7-19.8)$ \\
\hline 1999 & 38 & 4,348 & 165,224 & 25,698 & 0 & 15.55 & $(11.8-21.0)$ \\
\hline 2000 & 26 & 4,348 & 113,048 & $15,032^{\mathrm{e}}$ & 0 & 13.30 & $(11.14-15.86)$ \\
\hline 2001 & 131 & $3,978^{f}$ & 524,118 & - & - & - & - \\
\hline \multicolumn{8}{|c|}{ Lostine River } \\
\hline 1997 & 47 & 4,348 & 204,356 & 40,748 & 0 & 19.94 & $(13.41-30.99)$ \\
\hline 1998 & 28 & 4,348 & 121,744 & 28,084 & 0 & 23.07 & $(14.72-38.09)$ \\
\hline 1999 & 45 & 4,348 & 195,660 & 12,372 & 0 & 6.32 & $(5.15-7.76)$ \\
\hline 2000 & 53 & 4,348 & 230,444 & $33,086^{\mathrm{e}}$ & $0^{\mathrm{g}}$ & 14.36 & $(11.24-18.32)$ \\
\hline 2001 & 98 & $4,958^{\mathrm{h}}$ & 485,884 & - & - & - & - \\
\hline
\end{tabular}

${ }^{a}$ Redds counted above screw traps on Catherine Creek (rkm 32) and Lostine River (rkm 3).

${ }^{\mathrm{b}}$ Average number of eggs of wild spring chinook salmon spawned at Lookingglass Hatchery (ODFW, unpublished data).

${ }^{\mathrm{c}}$ Immature parr population estimate $\mathrm{x} \%$ of immature parr estimated to be age-0.

${ }^{\mathrm{d}}$ Mature population $x \%$ of mature parr estimated to be age- 0 .

${ }^{\mathrm{e}}$ All immature parr were assumed to be age-0.

${ }^{\mathrm{f}}$ Average number of eggs for 12 wild spring chinook salmon females spawned at Lookingglass Hatchery (ODFW, unpublished data).

got enough mature parr were marked to estimate the population size.

${ }^{\mathrm{h}}$ Average number of eggs for 24 wild spring chinook salmon females spawned at Lookingglass Hatchery $(O D F W$, unpublished data). 
Table 6. Population estimates, median emigration dates, and percentage of juvenile spring chinook salmon population moving as late migrants past traps sites, 1994 to 2001 migratory years. Early migratory period is from 1 July of the preceding year through 28 January of the migratory year. The late migratory period is from 29 January to 30 June.

\begin{tabular}{|c|c|c|c|c|}
\hline \multirow[b]{2}{*}{$\begin{array}{l}\text { Stream, } \\
\text { migratory year }\end{array}$} & \multirow[b]{2}{*}{$\begin{array}{c}\text { Population } \\
\text { estimate }\end{array}$} & \multicolumn{2}{|c|}{ Median emigration date } & \multirow[b]{2}{*}{$\begin{array}{c}\text { Percentage } \\
\text { migrating late }\end{array}$} \\
\hline & & $\begin{array}{c}\text { Early } \\
\text { migrants }\end{array}$ & Late migrants & \\
\hline \multicolumn{5}{|c|}{ Upper Grande Ronde River } \\
\hline 1994 & 25,398 & $14 \mathrm{Oct}$ & $01 \mathrm{Apr}$ & 87 \\
\hline 1995 & $38,725^{\mathrm{a}}$ & $30 \mathrm{Oct}$ & 02 Apr & 87 \\
\hline 1996 & 1,118 & $14 \mathrm{Oct}^{\mathrm{b}}$ & $16 \mathrm{Mar}$ & 99 \\
\hline 1997 & 82 & $14 \mathrm{Nov}$ & $26 \mathrm{Apr}^{\mathrm{b}}$ & 17 \\
\hline 1998 & 6,922 & 31 Oct & 23 Mar & 65 \\
\hline 1999 & 14,858 & $16 \mathrm{Nov}$ & 31 Mar & 84 \\
\hline 2000 & 14,780 & 30 Oct & 03 Apr & 74 \\
\hline 2001 & 51 & $01 \mathrm{Sep}^{\mathrm{b}}$ & $10 \mathrm{Apr}$ & 88 \\
\hline \multicolumn{5}{|l|}{ Catherine Creek } \\
\hline 1995 & $17,633^{\mathrm{c}}$ & - & $21 \mathrm{Mar}$ & - \\
\hline 1996 & 6,857 & 19 Oct & $11 \mathrm{Mar}$ & 27 \\
\hline 1997 & $4,442^{\mathrm{c}}$ & - & $13 \mathrm{Mar}$ & - \\
\hline 1998 & 9,881 & 30 Oct & 19 Mar & 29 \\
\hline 1999 & 20,311 & 14 Nov & 23 Mar & 38 \\
\hline 2000 & 23,991 & 31 Oct & $23 \mathrm{Mar}$ & 18 \\
\hline 2001 & 21,937 & 08 Oct & $24 \mathrm{Mar}$ & 13 \\
\hline \multicolumn{5}{|l|}{ Lostine River } \\
\hline 1997 & $4,496^{\mathrm{c}}$ & - & $30 \mathrm{Mar}$ & - \\
\hline 1998 & 17,539 & 30 Oct & $26 \mathrm{Mar}$ & 35 \\
\hline 1999 & 34,267 & $12 \mathrm{Nov}$ & $18 \mathrm{Apr}$ & 41 \\
\hline 2000 & 12,250 & $02 \mathrm{Nov}$ & $09 \mathrm{Apr}$ & 32 \\
\hline 2001 & 13,610 & 29 Sep & $20 \mathrm{Apr}$ & 23 \\
\hline \multicolumn{5}{|l|}{ Minam River } \\
\hline 2001 & $28,209^{c}$ & 08 Oct & 27 Mar & 64 \\
\hline
\end{tabular}

a Trap was located at rkm 257 in MY 1995.

b Median date based on small sample size: MY 1996, n=4; MY 1997, n=6; MY 2001, n=2.

c Trap was started late and may have missed a substantial number of early migrants. Median date of early migrants may not be accurate. 
Table 7. Catch of juvenile spring chinook salmon at five trap locations in the Grande Ronde River basin during the 2001 migratory year. The early migration period was from 1 July 2000 28 January 2001. The late migratory group was from 29 January - 30 June 2001.

\begin{tabular}{|c|c|c|c|c|c|}
\hline \multicolumn{2}{|c|}{ Trap site } & $\begin{array}{l}\text { Migratory } \\
\text { group }\end{array}$ & Trapping period & $\begin{array}{l}\text { Days } \\
\text { fished }\end{array}$ & $\begin{array}{l}\text { Trap } \\
\text { catch }\end{array}$ \\
\hline \multirow{2}{*}{\multicolumn{2}{|c|}{ Upper Grande Ronde River }} & Early & $01 \mathrm{Jul} 00-11$ Nov 00 & 99 & 2 \\
\hline & & Late & 18 Mar 01 - 30 Jun 01 & 84 & 17 \\
\hline \multirow{3}{*}{\multicolumn{2}{|c|}{ Catherine Creek }} & Early & $01 \mathrm{Jul} 00-06$ Dec 00 & 137 & 6,981 \\
\hline & & Late & 20 Feb $01-30$ Jun 01 & 91 & $659^{\mathrm{a}}$ \\
\hline & & Late & 16 Apr $01-22$ Apr 01 & 7 & $19^{\mathrm{b}}$ \\
\hline \multirow{2}{*}{\multicolumn{2}{|c|}{ Grande Ronde Valley }} & Early & 04 Oct $00-12$ Jan 01 & 69 & 19 \\
\hline & & Late & 01 Feb $01-20$ Jun 01 & 93 & 403 \\
\hline \multirow{4}{*}{\multicolumn{2}{|c|}{ Lostine River }} & Early & 01 Jul $00-28$ Jan 01 & 194 & 3,596 \\
\hline & & Late & 29 Jan $01-30$ Jun 01 & 116 & $668^{\mathrm{a}}$ \\
\hline & & Late & 29 Mar $01-07$ Apr 01 & 10 & $98^{\mathrm{b}}$ \\
\hline & & Late & 26 Apr $01-28$ Apr 01 & 3 & $56^{\mathrm{b}}$ \\
\hline \multirow{2}{*}{\multicolumn{2}{|c|}{ Minam River }} & Early & 27 Sep $00-16$ Nov 00 & 47 & 1,382 \\
\hline & & Late & 22 Feb $01-18$ Jun 01 & 92 & 2,072 \\
\hline \multicolumn{6}{|c|}{$\begin{array}{l}\text { a } \text { Continuous trapping. } \\
\text { b Trapping with subsampling. }\end{array}$} \\
\hline \multicolumn{6}{|c|}{$\begin{array}{l}\text { Table } 8 \text {. Fork lengths }(\mathrm{mm}) \text { of juvenile spring chinook salmon collected from the upper Grande } \\
\text { Ronde River during MY 2001. Early and late migration period fish were captured with a rotary } \\
\text { screw trap at } \mathrm{rkm} 299 . \text { Min. = minimum, Max. = maximum. }\end{array}$} \\
\hline \multirow[b]{2}{*}{ Group } & \multicolumn{5}{|c|}{ Collected } \\
\hline & $n$ & Mean & SE & Min. & Max. \\
\hline Early migrants & 1 & 96 & - & - & - \\
\hline \multirow[t]{2}{*}{ Late migrants } & 7 & 107.9 & 2.14 & 100 & 115 \\
\hline & \multicolumn{5}{|c|}{ Tagged and released } \\
\hline Group & $n$ & Mean & SE & Min. & Max. \\
\hline Early migrants & 0 & - & - & - & - \\
\hline Late migrants & 6 & 108.7 & 2.35 & 100 & 115 \\
\hline
\end{tabular}


Table 9. Weights (g) of juvenile spring chinook salmon collected from the upper Grande Ronde River during MY 2001. Early and late migration period fish were captured with a rotary screw trap at rkm 299. Min. = minimum, Max. = maximum.

\begin{tabular}{lccccc}
\hline & \multicolumn{5}{c}{ Collected } \\
\cline { 2 - 6 } Group & $n$ & Mean & SE & Min. & Max. \\
\hline Early migrants & 1 & 9.8 & - & - & - \\
Late migrants & 5 & 13.1 & 0.86 & 11.3 & 16.4 \\
\hline \hline & $n$ & Mean & SE & Min. & Max. \\
\cline { 2 - 6 } Group & - & - & - & - & - \\
\hline Early migrants & 4 & 13.6 & 0.94 & 12.3 & 16.4 \\
Late migrants & & & & & \\
\hline
\end{tabular}

Table 10. Fork lengths ( $\mathrm{mm}$ ) of juvenile spring chinook salmon collected from Catherine Creek during MY 2001. Winter fish were captured with seines or dipnets in Catherine Creek from rkm 40 to 48 . Early and late migration period fish were captured with a rotary screw trap at rkm 32 . Min. $=$ minimum, Max. $=$ maximum.

\begin{tabular}{lrlllc}
\hline & \multicolumn{5}{c}{ Collected } \\
\cline { 2 - 6 } Group & $n$ & Mean & SE & Min. & Max. \\
\hline Early migrants & 1,159 & 81.0 & 0.25 & 49 & 105 \\
Winter group & 521 & 83.2 & 0.30 & 65 & 100 \\
Late migrants & 383 & 87.8 & 0.39 & 60 & 123 \\
\hline \hline & \multicolumn{5}{c}{ Tagged and released } \\
Group & $n$ & Mean & SE & Min. & Max. \\
\hline Early migrants & 508 & 84.4 & 0.28 & 65 & 105 \\
Winter group & 521 & 83.2 & 0.30 & 65 & 100 \\
Late migrants & 324 & 88.1 & 0.42 & 69 & 123 \\
\hline
\end{tabular}


Table 11. Weights (g) of juvenile spring chinook salmon collected from Catherine Creek during MY 2001. Winter fish were captured with seines or dipnets in Catherine Creek from rkm 40 to 48. Early and late migration period fish were captured with a rotary screw trap at rkm 32. Min. $=$ minimum, Max. $=$ maximum.

\begin{tabular}{lccccc}
\hline & \multicolumn{5}{c}{ Collected } \\
\cline { 2 - 6 } Group & $n$ & Mean & SE & Min. & Max. \\
\hline Early migrants & 863 & 6.0 & 0.06 & 1.4 & 13.4 \\
Winter group & 516 & 5.8 & 0.07 & 2.3 & 10.6 \\
Late migrants & 278 & 7.5 & 0.15 & 2.4 & 23.2 \\
\hline \hline & $n$ & Mean & Tagged and released \\
Group & 6.7 & 0.08 & 3.0 & 13.4 \\
\hline Early migrants & 383 & 6.8 & 0.07 & 2.3 & 10.6 \\
Winter group & 516 & 7.8 & 0.17 & 3.2 & 23.2 \\
Late migrants & 225 & \multicolumn{5}{c}{ Max. } \\
\hline
\end{tabular}

Table 12. Fork lengths (mm) of juvenile spring chinook salmon collected from the Lostine River during MY 2001. Winter fish were captured with dipnets in the Lostine River from rkm 8 to 20. Early and late migration period fish were captured with a rotary screw trap at rkm 3 . Min. $=$ minimum, Max. $=$ maximum.

\begin{tabular}{lrcccc}
\hline & \multicolumn{5}{c}{ Collected } \\
\cline { 2 - 6 } Group & $n$ & Mean & SE & Min. & Max. \\
\hline Early migrants & 1,397 & 91.6 & 0.33 & 50 & 134 \\
Winter group & 498 & 88.7 & 0.39 & 63 & 115 \\
Late migrants & 647 & 100.8 & 0.47 & 73 & 148 \\
\hline \hline & \multicolumn{5}{c}{ Tagged and released } \\
Group & $n$ & Mean & SE & Min. & Max. \\
\hline Early migrants & 497 & 95.8 & 0.37 & 74 & 122 \\
Winter group & 498 & 88.7 & 0.39 & 63 & 115 \\
Late migrants & 434 & 100.9 & 0.57 & 75 & 148 \\
\hline
\end{tabular}


Table 13. Weights (g) of juvenile spring chinook salmon collected from the Lostine River during MY 2001. Winter fish were captured with dipnets in the Lostine River from rkm 8 to 20. Early and late migration period fish were captured with a rotary screw trap at $\mathrm{rkm} 3$. Min. $=$ minimum, Max. $=$ maximum .

\begin{tabular}{lrrrrl}
\hline & \multicolumn{5}{c}{ Collected } \\
\cline { 2 - 6 } Group & $n$ & Mean & SE & Min. & Max. \\
\hline Early migrants & 1,306 & 9.4 & 0.09 & 1.2 & 29.2 \\
Winter group & 389 & 7.6 & 0.11 & 2.8 & 17.5 \\
Late migrants & 633 & 12.0 & 0.20 & 4.5 & 49.7 \\
\hline \hline & \multicolumn{5}{c}{ Tagged and released } \\
Group & $n$ & Mean & SE & Min. & Max. \\
\hline Early migrants & 463 & 10.2 & 0.13 & 4.6 & 21.1 \\
Winter group & 389 & 7.6 & 0.11 & 2.8 & 17.5 \\
Late migrants & 433 & 12.0 & 0.24 & 4.5 & 35.4 \\
\hline
\end{tabular}

Table 14. Fork lengths (mm) of juvenile spring chinook salmon collected from the Minam River during MY 2001. Early and late migration period fish were captured with a rotary screw trap at rkm 0. Min. = minimum, Max. $=$ maximum.

\begin{tabular}{|c|c|c|c|c|c|}
\hline \multirow[b]{2}{*}{ Group } & \multicolumn{5}{|c|}{ Collected } \\
\hline & $n$ & Mean & $\mathrm{SE}$ & Min. & Max. \\
\hline Early migrants & 514 & 85.4 & 0.41 & 57 & 115 \\
\hline \multirow[t]{2}{*}{ Late migrants } & 1,102 & 90.1 & 0.24 & 62 & 148 \\
\hline & \multicolumn{5}{|c|}{ Tagged and released } \\
\hline Group & $n$ & Mean & SE & Min. & Max. \\
\hline Early migrants & 297 & 85.8 & 0.52 & 57 & 106 \\
\hline Late migrants & 536 & 90.4 & 0.35 & 69 & 148 \\
\hline
\end{tabular}


Table 15. Weights (g) of juvenile spring chinook salmon collected from the Minam River during MY 2001. Early and late migration period fish were captured with a rotary screw trap at rkm 0. Min. $=$ minimum, Max. $=$ maximum .

\begin{tabular}{|c|c|c|c|c|c|}
\hline \multirow[b]{2}{*}{ Group } & \multicolumn{5}{|c|}{ Collected } \\
\hline & $n$ & Mean & SE & Min. & Max. \\
\hline Early migrants & 487 & 7.2 & 0.11 & 2.3 & 18.6 \\
\hline \multirow[t]{2}{*}{ Late migrants } & 1,096 & 8.1 & 0.07 & 2.8 & 38.5 \\
\hline & \multicolumn{5}{|c|}{ Tagged and released } \\
\hline Group & $n$ & Mean & $\mathrm{SE}$ & Min. & Max. \\
\hline Early migrants & 270 & 7.2 & 0.13 & 2.3 & 14.5 \\
\hline Late migrants & 532 & 8.2 & 0.11 & 3.5 & 38.5 \\
\hline
\end{tabular}

Table 16. Comparison of spring chinook salmon parr survival indices based on first-time dam detection rates of PIT-tagged parr and Cormack-Jolly-Seber estimates of survival probabilities, listed by stream and tag group for the 2001 migratory year. Dam detection rate includes all firsttime detections at the six Snake River and Columbia River dams with PIT tag detection capability. Survival probability is survival from rearing areas to Lower Granite Dam.

\begin{tabular}{lcccccc}
\hline & Number & \multicolumn{2}{c}{ Dam detection rates } & & \multicolumn{2}{c}{ CJS survival probabilities } \\
Stream, tag group & Released & Rate & $95 \%$ CI & & Probability & $95 \%$ CI \\
\hline Catherine Creek & & & & & & \\
$\quad$ Fall & 508 & 0.128 & $0.100-0.160$ & & 0.130 & $0.103-0.162$ \\
$\quad$ Winter & 522 & 0.069 & $0.049-0.094$ & & 0.077 & $0.054-0.106$ \\
$\quad$ Spring & 328 & 0.360 & $0.308-0.414$ & & 0.376 & $0.322-0.433$
\end{tabular}

Lostine River

$\begin{array}{llllll}\text { Fall } & 498 & 0.329 & 0.288-0.373 & 0.335 & 0.294-0.378 \\ \text { Winter } & 499 & 0.277 & 0.238-0.318 & 0.284 & 0.245-0.326 \\ \text { Spring } & 442 & 0.663 & 0.617-0.707 & 0.689 & 0.641-0.735\end{array}$

Minam River

$\begin{array}{llllll}\text { Fall } & 300 & 0.420 & 0.364-0.478 & 0.427 & 0.371-0.485 \\ \text { Spring } & 536 & 0.605 & 0.562-0.646 & 0.619 & 0.576-0.661\end{array}$

Upper Grande Ronde River Spring 6 0.833 $0.359-0.996$ 
Table 17. Detection rates and CJS survival probabilities to Lower Granite Dam for spring chinook salmon parr tagged in summer 2000 and detected at Columbia and Snake River dams in 2001. Detection rates and survival probabilities that have a letter in common are not significantly different $(P \leq 0.05)$.

\begin{tabular}{|c|c|c|c|}
\hline Stream & $\begin{array}{l}\text { Number } \\
\text { released }\end{array}$ & $\begin{array}{c}\text { Dam detection rate } \\
(95 \% \mathrm{CI})\end{array}$ & $\begin{array}{l}\text { Survival probability } \\
(95 \% \mathrm{CI})\end{array}$ \\
\hline Catherine Creek & 498 & $(0.060-0.110)$ & $(0.063-0.115)$ \\
\hline Imnaha River & 1,000 & $0.180^{\mathrm{a}} \quad(0.157-0.205)$ & $(0.158-0.206)$ \\
\hline Lostine River & 489 & $0.207^{\mathrm{ab}}(0.172-0.245)$ & $0.210^{\mathrm{c}}(0.175-0.248)$ \\
\hline Minam River & 1,000 & $0.221^{\mathrm{b}}(0.196-0.248)$ & $0.228^{\mathrm{c}}(0.202-0.256)$ \\
\hline
\end{tabular}

Table 18. Sampling reaches on North Fork Catherine Creek for estimating the population of $O$. mykiss in summer 2001.

\begin{tabular}{rllr}
\hline Reach & Start location & End location & Length $(\mathrm{m})$ \\
\hline 1 & Mouth, rkm 0.0 & Middle Fork confluence, rkm 4.51 & 4,510 \\
2 & Middle Fork confluence, rkm 4.51 & Jim Creek confluence, rkm 8.56 & 4,050 \\
3 & Jim Creek confluence, rkm 8.56 & $\begin{array}{l}\text { 0.1 mile below Amelia Spring } \\
\text { confluence, rkm 12.42 }\end{array}$ & 3,860 \\
4 & $\begin{array}{l}\text { 0.1 mile below Amelia Spring } \\
\text { confluence, rkm 12.42 }\end{array}$ & $\begin{array}{l}\text { North end of meadow just } \\
\text { upstream of where trail crosses } \\
\text { creek, rkm 14.44 }\end{array}$ & 2,020 \\
5 & $\begin{array}{l}\text { North end of meadow just } \\
\text { upstream of where trail crosses } \\
\text { creek, rkm 14.44 }\end{array}$ & $\begin{array}{l}\text { Falls (barrier to upstream } \\
\text { movement by fish), rkm 16.59 }\end{array}$ & 2,150 \\
\hline
\end{tabular}

Table 19. Sampling methods specific to reaches 2 and 3 on North Fork Catherine Creek for estimating the population of $O$. mykiss in summer 2001.

\begin{tabular}{lcc}
\hline Reach information, sampling scheme & Reach 2 & Reach 3 \\
\hline & & \\
Length of reach (m) & 4,050 & 3,860 \\
Number of 61 m segments & 66.4 & 63.3 \\
Frequency of snorkeled segments & $1 / 5$ & $1 / 6$ \\
Number snorkeled segments, \% of reach snorkeled & $10,15 \%$ & $11,17 \%$ \\
Frequency of depletion sampled segments & $1 / 3$ of snorkeled & $1 / 3$ of snorkeled \\
Number snorkeled and depleted segments & 4 & 4 \\
\hline
\end{tabular}


Table 20. Sampling methods specific to reaches 4 and 5 on North Fork Catherine Creek for estimating the population of $O$. mykiss in summer 2001.

\begin{tabular}{|c|c|c|}
\hline $\begin{array}{l}\text { Habitat type, } \\
\text { sampling scheme }\end{array}$ & Reach 4 & Reach 5 \\
\hline \multicolumn{3}{|l|}{ Pools } \\
\hline total & 74 & 45 \\
\hline snorkeled & $16\left(\right.$ every $\left.6^{\text {th }}\right)$ & 15 (every $3^{\text {rd }}$ ) \\
\hline depletion sampled & 4 (every $3^{\text {rd }}$ snorkeled) & 4 (every $3^{\text {rd }}$ snorkeled) \\
\hline \multicolumn{3}{|l|}{ Riffles } \\
\hline total & 45 & 53 \\
\hline snorkeled & $11\left(\right.$ every $\left.4^{\text {th }}\right)$ & 0 \\
\hline depletion sampled & 5 (every $2^{\text {nd }}$ snorkeled) & 5 (every $\left.8^{\text {th }}\right)$ \\
\hline \multicolumn{3}{|l|}{ Side channels } \\
\hline total & 1 & 5 \\
\hline snorkeled & 0 & 0 \\
\hline depletion sampled & 0 & $1\left(\right.$ every $\left.3^{\text {rd }}\right)$ \\
\hline \multicolumn{3}{|l|}{ Complex units } \\
\hline total & 0 & 7 \\
\hline snorkeled & 0 & $4\left(\right.$ every $\left.2^{\text {nd }}\right)$ \\
\hline depletion sampled & 0 & 1 (every $2^{\text {nd }}$ snorkeled) \\
\hline
\end{tabular}


Table 21. Population estimates of $O$. mykiss in the Catherine Creek watershed in summer 2001. Estimation methods: $\mathrm{a}=$ mark-recapture, Peterson estimate; $\mathrm{b}=$ Hankin and Reeves, equal length units, calibrated snorkel counts; $\mathrm{c}=$ Hankin and Reeves, habitat units, uncalibrated snorkel counts.

\begin{tabular}{|c|c|c|c|c|c|c|}
\hline \multirow[b]{2}{*}{ Stream, reach } & \multirow[b]{2}{*}{ Method } & \multicolumn{3}{|c|}{ Mark-recapture data } & \multicolumn{2}{|c|}{ Population estimate } \\
\hline & & $\begin{array}{c}\text { Marked } \\
\text { (M) }\end{array}$ & $\begin{array}{l}\text { Recaptured } \\
\text { (R) }\end{array}$ & $\begin{array}{l}\text { Sampled } \\
\text { (C) }\end{array}$ & $\begin{array}{l}\text { Number } \\
(\mathrm{N})\end{array}$ & $95 \% \mathrm{CI}$ \\
\hline \multicolumn{7}{|c|}{ Catherine Creek } \\
\hline \multicolumn{7}{|c|}{ North Fork Catherine Creek } \\
\hline 1 & $\mathrm{a}$ & 305 & 9 & 290 & 8,905 & $4,920-17,809$ \\
\hline 2 & $\mathrm{~b}$ & & & & 1,093 & $698-1,489$ \\
\hline 3 & $\mathrm{~b}$ & & & & 187 & $85-289$ \\
\hline 4 & $\mathrm{c}$ & & & & 147 & $80-214$ \\
\hline 5 & $\mathrm{c}$ & & & & 11 & $0-13$ \\
\hline All reaches & & & & & 10,338 & $5,137-15,539$ \\
\hline
\end{tabular}

Table 22. Growth rates (mm/d) of $O$. mykiss tagged 27 June - 31 July 2000 upstream of the Catherine Creek screw trap and recaptured at the screw trap in fall 2000 and spring 2001, and upstream in summer 2001.

\begin{tabular}{lrcccc}
\hline & & & \multicolumn{2}{c}{ Growth rate $(\mathrm{mm} / \mathrm{d})$} \\
\cline { 5 - 6 } Season of recapture, location & $\mathrm{N}$ & Recapture dates & Mean & $95 \%$ CI \\
\hline Fall 2000, trap & 20 & 18 Sep - 5 Dec & 0.173 & \pm 0.039 \\
Spring 2001, trap & 6 & 21 Mar - 10 Apr & 0.059 & \pm 0.037 \\
Summer 2001, upstream & 1 & 26 Jun & 0.073 & - \\
\hline
\end{tabular}


Table 23. Catch of juvenile O. mykiss at five trap locations in the Grande Ronde River basin during the 2001 migratory year.

\begin{tabular}{|c|c|c|c|c|}
\hline Trap site & $\begin{array}{l}\text { Migratory } \\
\text { group }\end{array}$ & Trapping period & $\begin{array}{l}\text { Days } \\
\text { fished }\end{array}$ & $\begin{array}{l}\text { Trap } \\
\text { catch }\end{array}$ \\
\hline \multirow[t]{2}{*}{ Upper Grande Ronde River } & Early & 01 Jul $00-11$ Nov 00 & 99 & 308 \\
\hline & Late & 18 Mar $01-30$ Jun 01 & 84 & 2,337 \\
\hline \multirow[t]{3}{*}{ Catherine Creek } & Early & $01 \mathrm{Jul} 00-06$ Dec 00 & 137 & 3,561 \\
\hline & Late & 20 Feb $01-30$ Jun 01 & 91 & $1,205^{\mathrm{a}}$ \\
\hline & Late & 16 Apr $01-22$ Apr 01 & 7 & $54^{\mathrm{b}}$ \\
\hline \multirow[t]{2}{*}{ Grande Ronde Valley } & Early & 04 Oct $00-12$ Jan 01 & 69 & 74 \\
\hline & Late & 01 Feb $01-20$ Jun 01 & 93 & 3,437 \\
\hline \multirow[t]{4}{*}{ Lostine River } & Early & 01 Jul $00-28$ Jan 01 & 194 & 1,636 \\
\hline & Late & 29 Jan $01-30$ Jun 01 & 116 & $697^{\mathrm{a}}$ \\
\hline & Late & 29 Mar $01-07$ Apr 01 & 10 & $193^{b}$ \\
\hline & Late & 26 Apr $01-28$ Apr 01 & 3 & $30^{\mathrm{b}}$ \\
\hline \multirow[t]{2}{*}{ Minam River } & Early & 27 Sep $00-16$ Nov 00 & 47 & 214 \\
\hline & Late & 22 Feb $01-18$ Jun 01 & 92 & 1,123 \\
\hline
\end{tabular}

\footnotetext{
a Continuous trapping.

b Trapping with subsampling.
} 
Table 24. Population estimates, median emigration dates, and percentage of $O$. mykiss population moving as late migrants past traps sites, 1997 to 2001 migratory years. Early migratory period is from 1 July of the preceding year through 28 January of the migratory year. The late migratory period is from 29 January to 30 June.

\begin{tabular}{|c|c|c|c|c|}
\hline \multirow[b]{2}{*}{$\begin{array}{l}\text { Stream, } \\
\text { migratory year }\end{array}$} & \multirow[b]{2}{*}{$\begin{array}{c}\text { Population } \\
\text { estimate }\end{array}$} & \multicolumn{2}{|c|}{ Median emigration date } & \multirow[b]{2}{*}{$\begin{array}{c}\text { Percentage } \\
\text { migrating late }\end{array}$} \\
\hline & & $\begin{array}{c}\text { Early } \\
\text { migrants }\end{array}$ & $\begin{array}{c}\text { Late } \\
\text { migrants }\end{array}$ & \\
\hline \multicolumn{5}{|c|}{ Upper Grande Ronde River } \\
\hline 1997 & 15,104 & $25 \mathrm{Oct}$ & 27 Mar & 92 \\
\hline 1998 & 10,133 & 08 Aug & 27 Mar & 60 \\
\hline 1999 & 6,108 & $08 \mathrm{Nov}$ & $29 \mathrm{Apr}$ & 95 \\
\hline 2000 & 17,845 & $30 \mathrm{Sep}$ & $08 \mathrm{Apr}$ & 94 \\
\hline 2001 & 16,067 & $11 \mathrm{Oct}$ & 07 May & 96 \\
\hline \multicolumn{5}{|l|}{ Catherine Creek } \\
\hline 1997 & $25,229^{\mathrm{a}}$ & - & $14 \mathrm{Apr}$ & - \\
\hline 1998 & 20,742 & $22 \mathrm{Sep}$ & $04 \mathrm{Apr}$ & 58 \\
\hline 1999 & 19,628 & $02 \mathrm{Nov}$ & $15 \mathrm{Apr}$ & 75 \\
\hline 2000 & 35,699 & 30 Oct & $16 \mathrm{Apr}$ & 61 \\
\hline 2001 & 20,586 & 06 Oct & $31 \mathrm{Mar}$ & 56 \\
\hline \multicolumn{5}{|l|}{ Lostine River } \\
\hline 1997 & $4,309^{b}$ & - & 01 May & - \\
\hline 1998 & 10,271 & 04 Oct & $24 \mathrm{Apr}$ & 46 \\
\hline 1999 & 23,643 & 17 Oct & 01 May & 35 \\
\hline 2000 & 11,981 & 19 Oct & $17 \mathrm{Apr}$ & 44 \\
\hline 2001 & 16,690 & 04 Oct & 29 Apr & 55 \\
\hline \multicolumn{5}{|l|}{ Minam River } \\
\hline 2001 & 28,113 & 3 Oct & 29 Apr & 86 \\
\hline
\end{tabular}

${ }^{a}$ Trap not started until week 39. Thereby potentially missing part of the early migration

${ }^{\mathrm{b}}$ Trap not started until week 43. Thereby potentially missing part of the early migration 
Table 25. Travel time to Lower Granite Dam of wild O. mykiss PIT-tagged at upstream screw traps in spring of 2001 and arriving at Lower Granite Dam in 2001.

\begin{tabular}{lcccc}
\hline & Number & \multicolumn{3}{c}{ Travel time (days) } \\
\cline { 5 - 5 } Stream & 88 & 33.0 & 33.2 & $7-74$ \\
Catherine Creek & 180 & 37.1 & 37.3 & $8-152$ \\
Upper Grande Ronde River & 164 & 17.6 & 13.9 & $5-109$ \\
Lostine River & 240 & 21.8 & 16.6 & $5-110$ \\
Minam River & & & & Mean \\
\hline
\end{tabular}

Table 26. Detections at Snake and Columbia River dams in 2001 of wild O. mykiss juveniles PIT-tagged at screw traps on Catherine Creek and the upper Grande Ronde, Lostine, and Minam rivers during fall 1999 and 2000.

\begin{tabular}{|c|c|c|c|c|}
\hline Stream, year tagged & $\begin{array}{c}\text { Number tagged } \\
\text { in fall }\end{array}$ & $\begin{array}{c}\text { Detections in } \\
2001\end{array}$ & \multicolumn{2}{|c|}{$\begin{array}{c}\text { Detection rate }(95 \% \mathrm{CI}) \\
\text { in } 2001\end{array}$} \\
\hline $\begin{array}{l}\text { Catherine Creek } \\
1999 \\
2000\end{array}$ & $\begin{array}{l}989 \\
561\end{array}$ & $\begin{array}{l}14 \\
67\end{array}$ & $\begin{array}{l}0.014 \\
0.119\end{array}$ & $\begin{array}{l}(0.008-0.024) \\
(0.094-0.149)\end{array}$ \\
\hline $\begin{array}{l}\text { Upper Grande Rond } \\
1999 \\
2000\end{array}$ & $\begin{array}{r}110 \\
61\end{array}$ & $\begin{array}{r}0 \\
12\end{array}$ & $\begin{array}{l}0 \\
0.197\end{array}$ & $\begin{array}{l}(0.000-0.033) \\
(0.106-0.318)\end{array}$ \\
\hline $\begin{array}{l}\text { Lostine River } \\
\qquad \begin{array}{l}1999 \\
2000\end{array}\end{array}$ & $\begin{array}{l}777 \\
421\end{array}$ & $\begin{array}{l}11 \\
17\end{array}$ & $\begin{array}{l}0.014 \\
0.040\end{array}$ & $\begin{array}{l}(0.007-0.025) \\
(0.024-0.064)\end{array}$ \\
\hline $\begin{array}{l}\text { Minam River } \\
2000\end{array}$ & 32 & 7 & 0.219 & $(0.093-0.400)$ \\
\hline
\end{tabular}


Table 27. Detections at Snake and Columbia River dams in 2001 of wild $O$. mykiss juveniles PIT-tagged at screw traps on Catherine Creek and the Grande Ronde, Lostine, and Minam rivers during spring 2000 and 2001. All PIT-tagged $O$. mykiss in spring were $\geq 115 \mathrm{~mm}$ FL.

\begin{tabular}{|c|c|c|c|c|}
\hline Stream, year tagged & $\begin{array}{l}\text { Number tagged } \\
\text { in spring }\end{array}$ & $\begin{array}{c}\text { Detections in } \\
2001\end{array}$ & \multicolumn{2}{|c|}{$\begin{array}{l}\text { Detection rate }(95 \% \mathrm{CI}) \\
\text { in } 2001\end{array}$} \\
\hline \multicolumn{5}{|l|}{ Catherine Creek } \\
\hline 2000 & 305 & 2 & 0.007 & $(0.001-0.023)$ \\
\hline 2001 & 247 & 96 & 0.389 & $(0.328-0.453)$ \\
\hline \multicolumn{5}{|c|}{ Upper Grande Ronde River } \\
\hline 2000 & 324 & 1 & 0.003 & $(0.000-0.017)$ \\
\hline 2001 & 465 & 196 & 0.422 & $(0.376-0.468)$ \\
\hline \multicolumn{5}{|l|}{ Lostine River } \\
\hline 2000 & 442 & 4 & 0.009 & $(0.002-0.023)$ \\
\hline 2001 & 323 & 182 & 0.563 & $(0.507-0.618)$ \\
\hline \multicolumn{5}{|l|}{ Minam River } \\
\hline 2001 & 442 & 269 & 0.609 & $(0.561-0.654)$ \\
\hline
\end{tabular}

Table 28. Detection rates at Snake and Columbia River dams of $O$. mykiss PIT-tagged on Catherine Creek and its tributaries during summer 2000.

\begin{tabular}{lccc}
\hline Stream & $\begin{array}{c}\text { Number } \\
\text { released }\end{array}$ & $\begin{array}{c}\text { Number detected } \\
\text { in 2001 }\end{array}$ & $\begin{array}{c}\text { Detection rate } \\
(95 \% \mathrm{CI})\end{array}$ \\
\hline Catherine Creek & & & \\
North Fork Catherine Creek & 112 & 22 & $0.053(0.034-0.080)$ \\
South Fork Catherine Creek & 225 & 2 & $0.017(0.002-0.060)$ \\
Little Catherine Creek & 415 & 0 & $0.022(0.007-0.051)$ \\
& & & 0 \\
Total & 1,169 & 29 & $0.025(0.017-0.009)$ \\
\hline
\end{tabular}


Table 29. Length at age of $O$. mykiss collected from the upper Grande Ronde River, Catherine Creek, the Lostine River, and the Minam River during the early and late migration periods. Min. $=$ minimum, Max. $=$ maximum.

\begin{tabular}{|c|c|c|c|c|c|c|}
\hline \multirow[b]{2}{*}{ Stream, age class } & \multirow[b]{2}{*}{$\mathrm{N}$} & \multirow{2}{*}{$\begin{array}{c}\text { Proportion of } \\
\text { total }(\%) \\
\end{array}$} & \multicolumn{4}{|c|}{ Fork length $(\mathrm{mm})$} \\
\hline & & & Mean & SE & Min. & Max \\
\hline & & & Early M & & & \\
\hline \multicolumn{7}{|c|}{ Upper Grande Ronde River } \\
\hline 0 & 5 & 14.7 & 93.8 & 3.09 & 86 & 101 \\
\hline 1 & 29 & 85.3 & 132.1 & 2.82 & 109 & 163 \\
\hline \multicolumn{7}{|l|}{ Catherine Creek } \\
\hline 0 & 14 & 14.0 & 102.6 & 4.49 & 69 & 135 \\
\hline 1 & 80 & 80.0 & 140.6 & 1.72 & 99 & 183 \\
\hline 2 & 6 & 6.0 & 183.2 & 8.25 & 164 & 219 \\
\hline & \multicolumn{6}{|c|}{ Late Migrants } \\
\hline \multicolumn{7}{|c|}{ Upper Grande Ronde River } \\
\hline 0 & 1 & 0.6 & 62.0 & - & - & - \\
\hline 1 & 94 & 53.7 & 96.4 & 1.29 & 64 & 130 \\
\hline 2 & 79 & 45.1 & 154.3 & 1.81 & 116 & 197 \\
\hline 3 & 1 & 0.6 & 186.0 & - & - & - \\
\hline \multicolumn{7}{|l|}{ Catherine Creek } \\
\hline 0 & 6 & 4.1 & 73.7 & 2.67 & 62 & 81 \\
\hline 1 & 95 & 64.6 & 92.5 & 1.44 & 62 & 128 \\
\hline 2 & 43 & 29.3 & 150.7 & 1.74 & 122 & 171 \\
\hline 3 & 3 & 2.0 & 165.7 & 2.19 & 163 & 170 \\
\hline \multicolumn{7}{|l|}{ Lostine River } \\
\hline 1 & 16 & 53.3 & 97.3 & 3.58 & 70 & 128 \\
\hline 2 & 14 & 46.7 & 160.9 & 4.63 & 139 & 192 \\
\hline \multicolumn{7}{|l|}{ Minam River } \\
\hline 1 & 32 & 72.7 & 91.1 & 1.98 & 68 & 121 \\
\hline 2 & 10 & 22.7 & 163.4 & 6.25 & 134 & 187 \\
\hline 3 & 2 & 4.5 & 207.0 & 2.00 & 205 & 209 \\
\hline
\end{tabular}




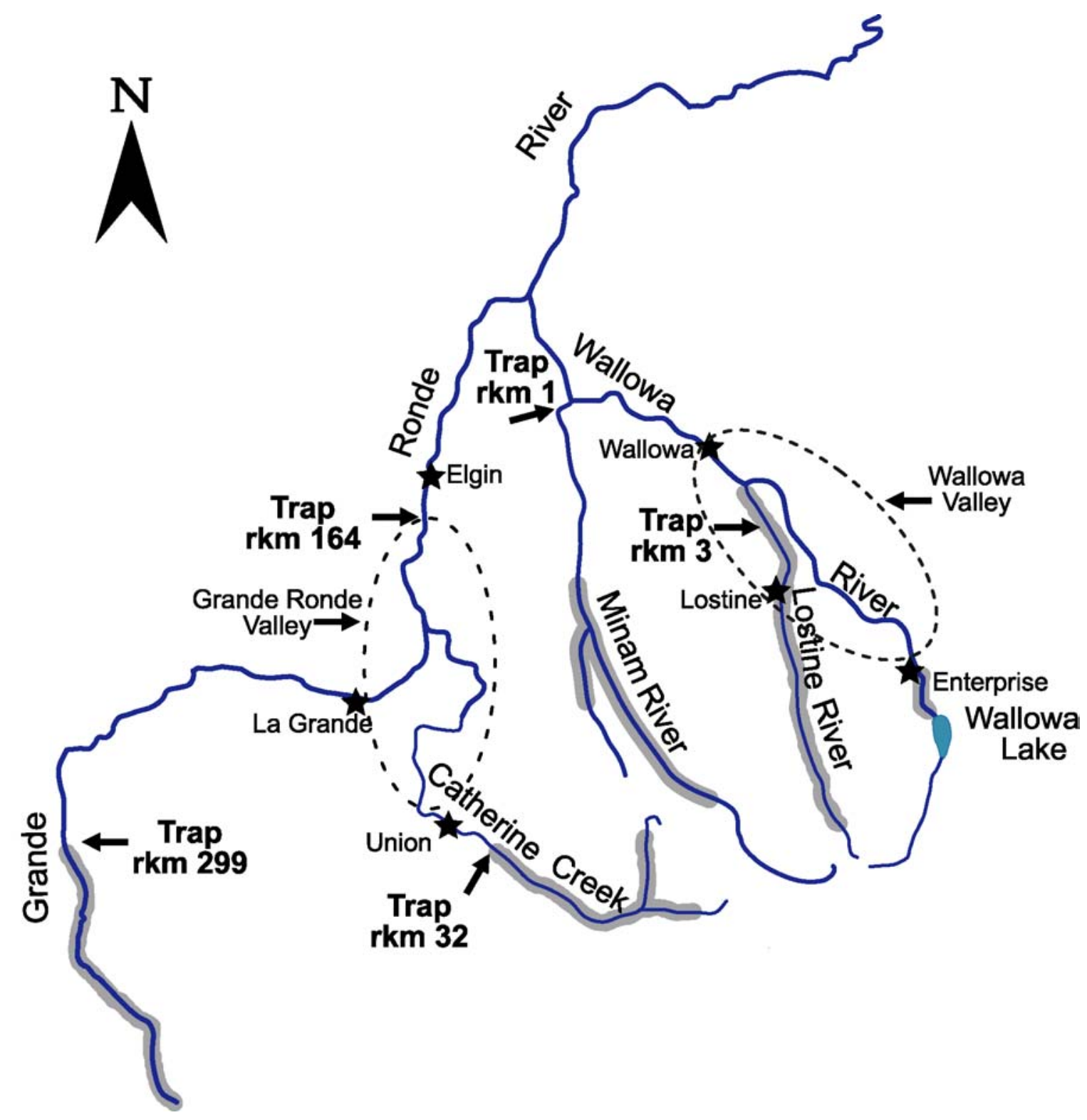

Figure 1. Locations of fish traps in the Grande Ronde River basin during the study period. Shaded areas delineate spring chinook salmon spawning and upper rearing areas in each study stream. Dashed lines indicate the Grande Ronde River and Wallowa River valleys. 


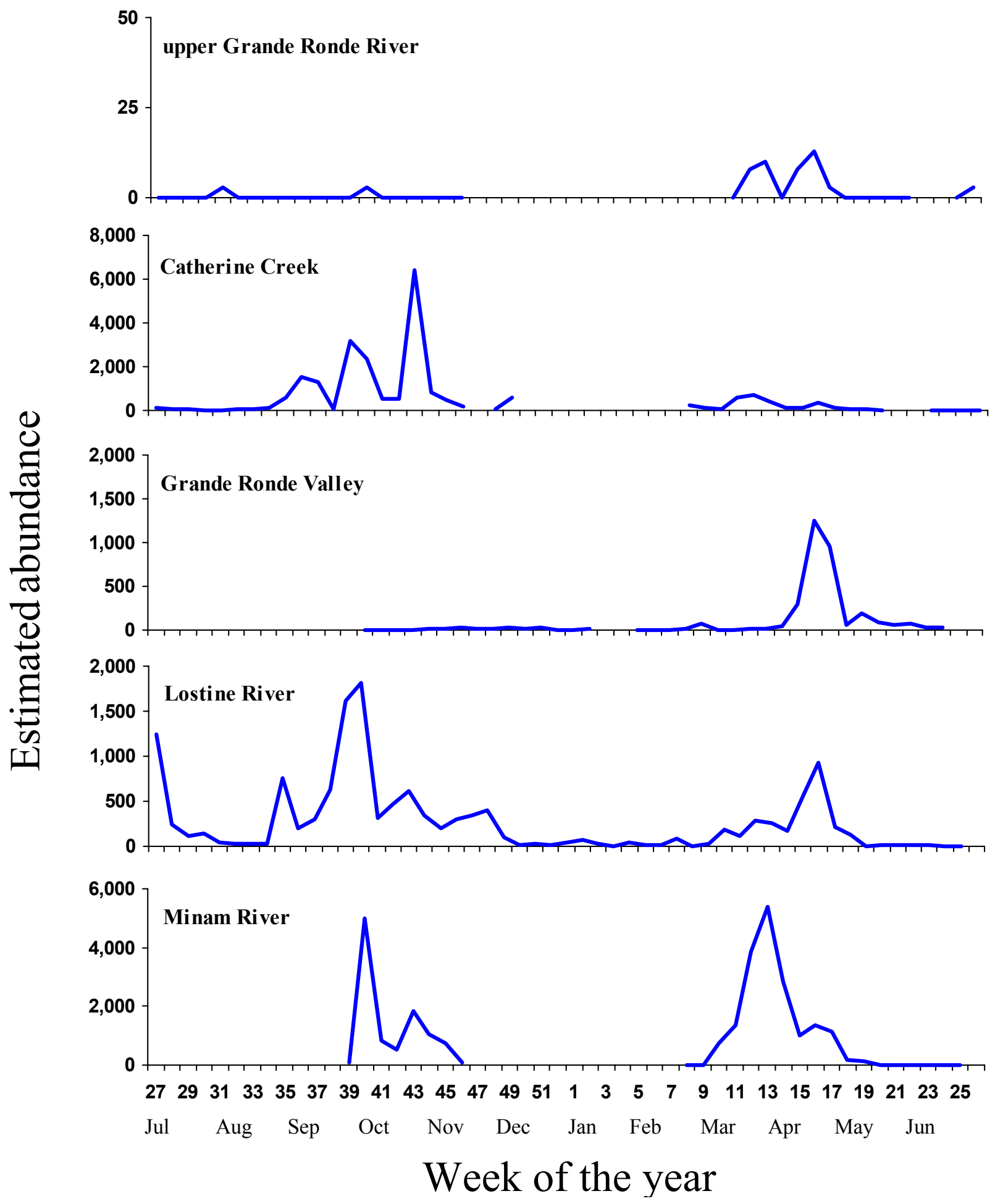

Figure 2. Estimated migration timing and abundance of juvenile spring chinook salmon migrants captured by rotary screw traps during the 2001 migratory year. Traps were located at rkm 299 and 164 of the Grande Ronde River, rkm 32 of Catherine Creek, rkm 3 of the Lostine River, and rkm 0 of the Minam River. 


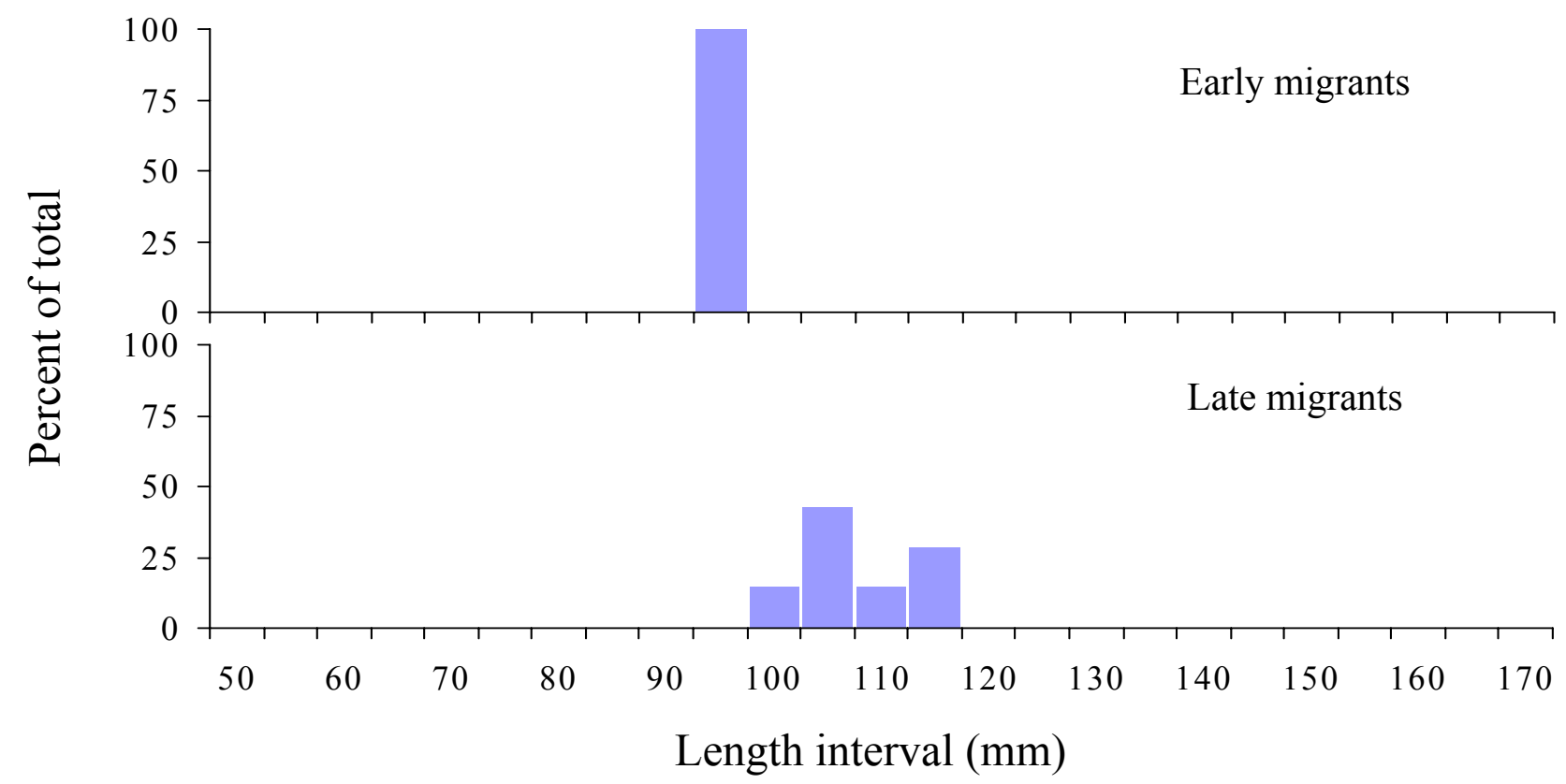

Figure 3. Length frequency distribution (fork length) of juvenile spring chinook salmon migrants captured at the upper Grande Ronde River trap (rkm 299) by migration period, during the 2001 migratory year. Only two early migrants and 17 late migrants were collected.

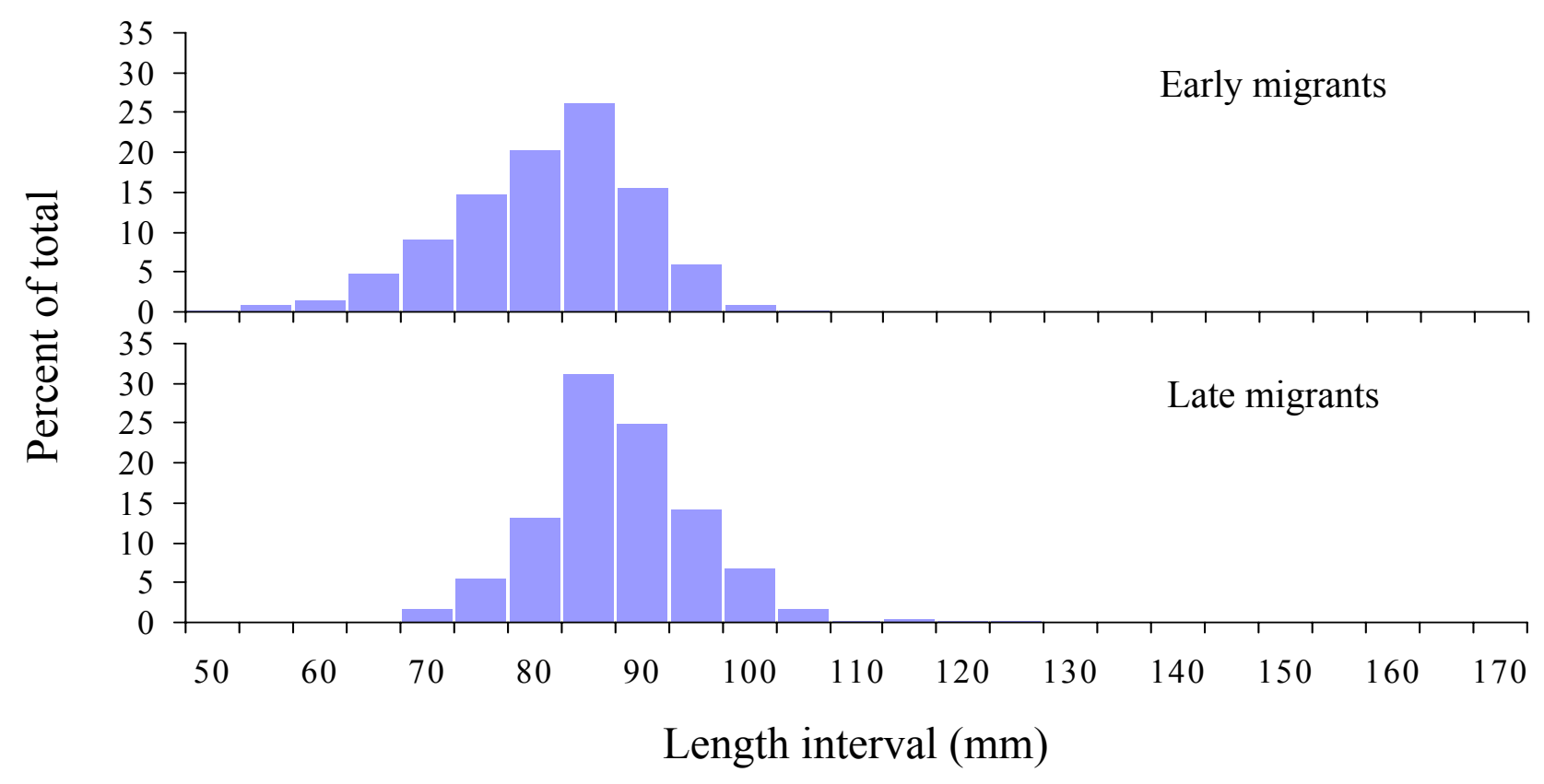

Figure 4. Length frequency distribution (fork length) of juvenile spring chinook salmon migrants captured at the Catherine Creek trap ( $\mathrm{rkm} 32$ ) by migration period, during the 2001 migratory year. 


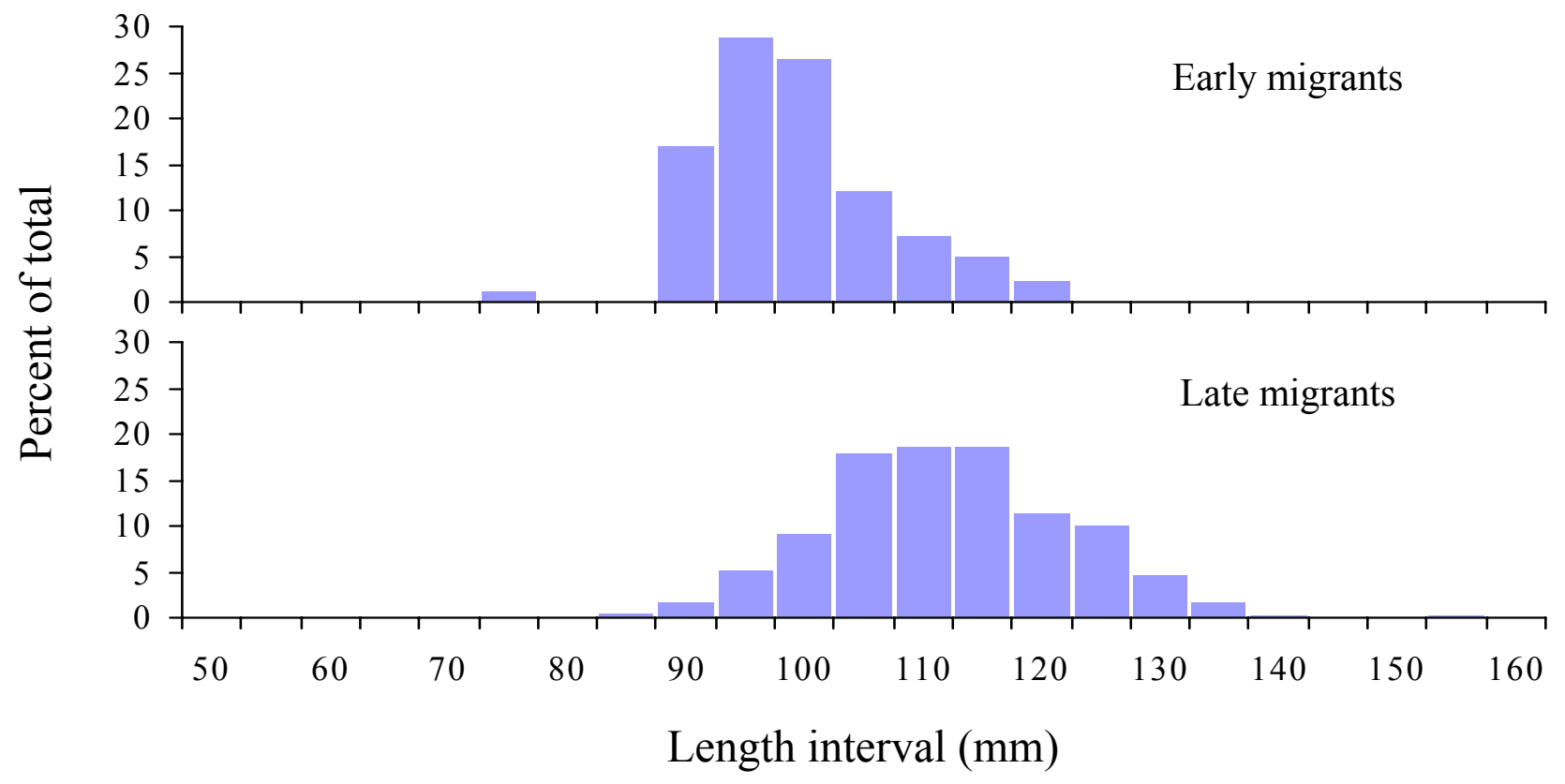

Figure 5. Length frequency distribution (fork length) of juvenile spring chinook salmon migrants captured at the Grande Ronde Valley trap (rkm 164) by migration period, during the 2001 migratory year.

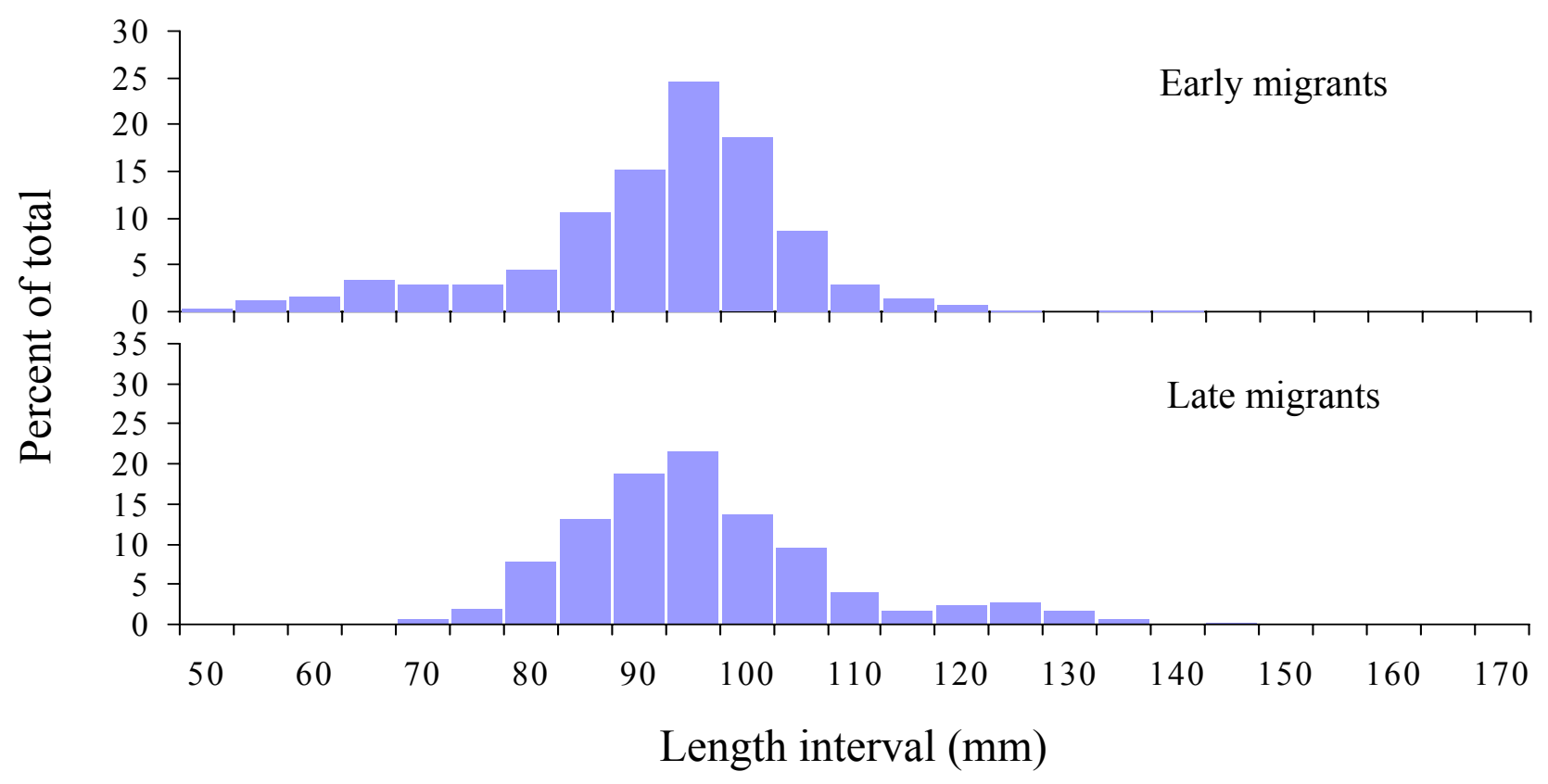

Figure 6. Length frequency distribution (fork length) of juvenile spring chinook salmon migrants captured at the Lostine River trap (rkm 3) by migration period, during the 2001 migratory year. 


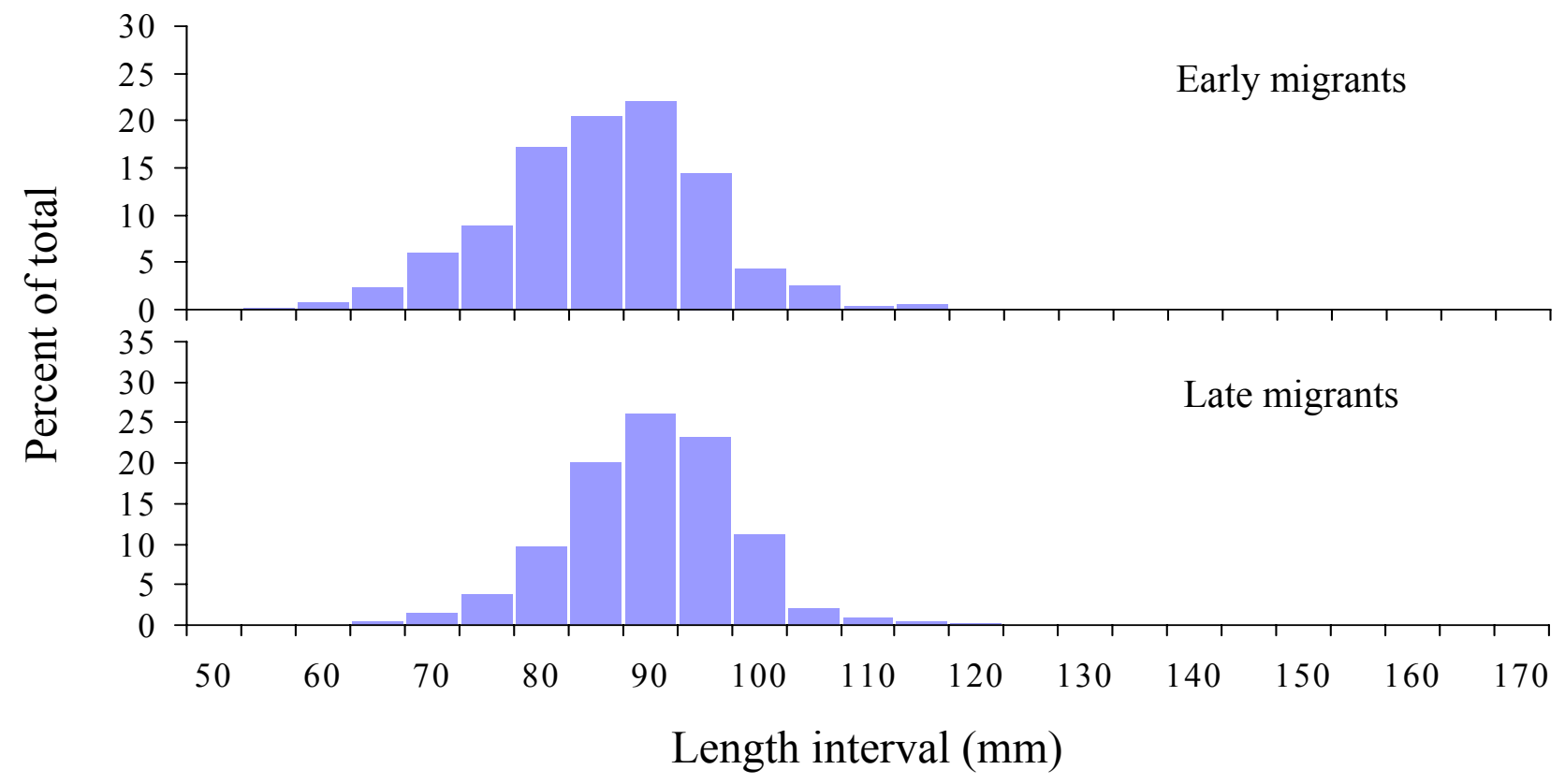

Figure 7. Length frequency distribution (fork length) of juvenile spring chinook salmon migrants captured at the Minam River trap ( $\mathrm{rkm}$ 0) by migration period, during the 2001 migratory year. 


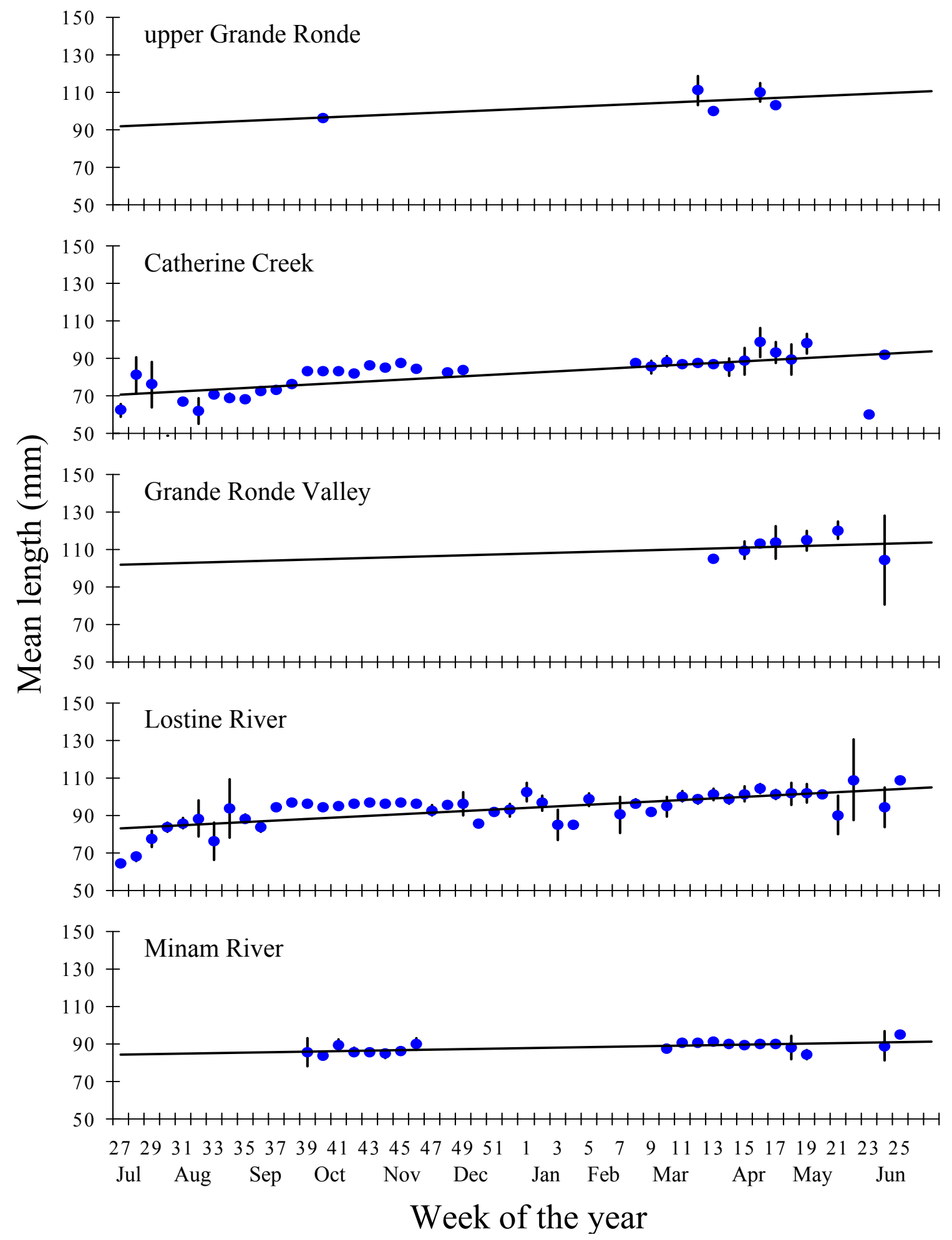

Figure 8. Weekly mean fork lengths $(\mathrm{mm})$ with standard error for spring chinook salmon captured in rotary screw traps in the Grande Ronde and Wallowa basins during migratory year 2001. 


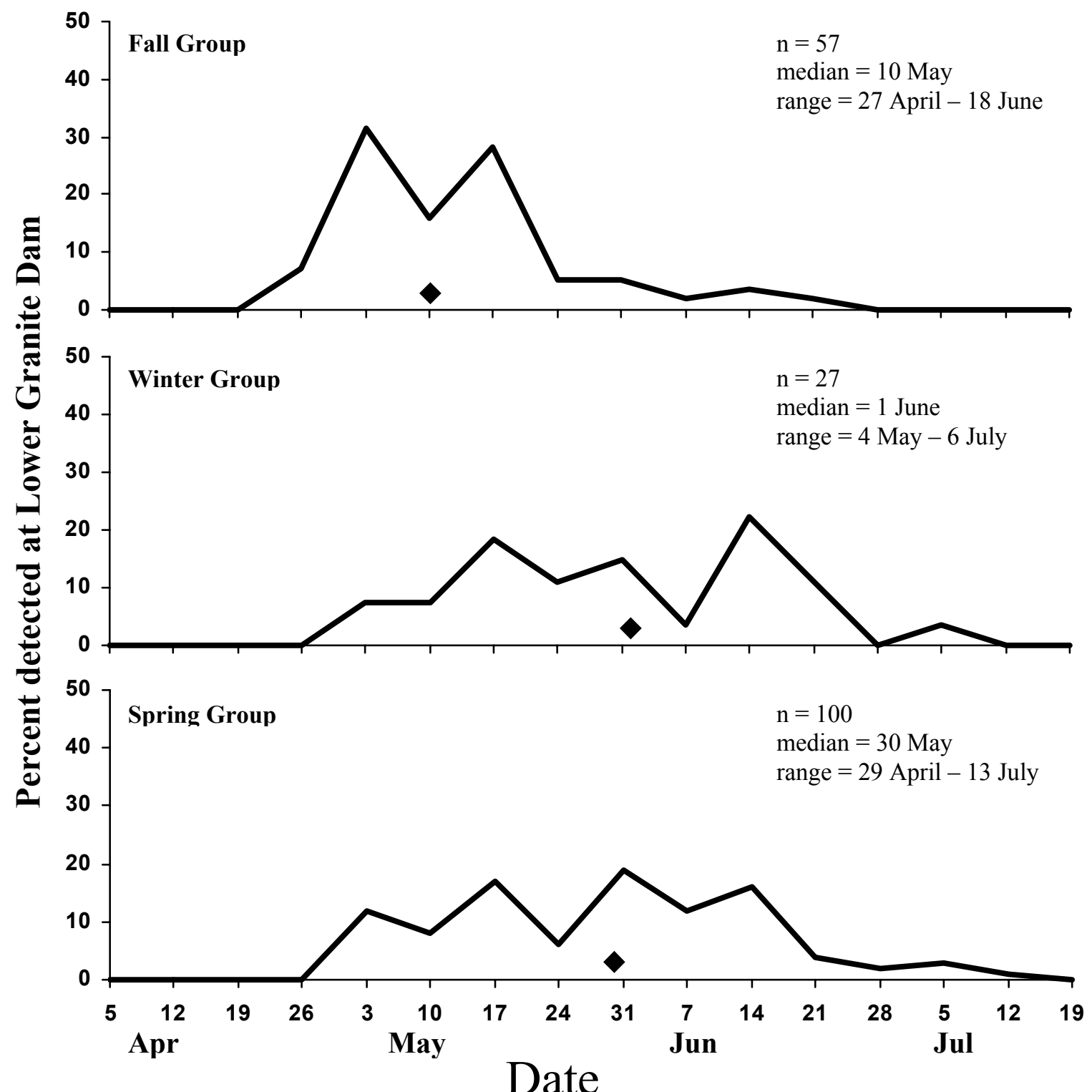

Figure 9. Dates of detection in 2001 at Lower Granite Dam for the fall, winter, and spring tag groups of juvenile spring chinook salmon PIT-tagged on Catherine Creek, expressed as a percentage of the total detected for each group. $\bullet=$ median arrival date. Detections were expanded for spillway flow. 


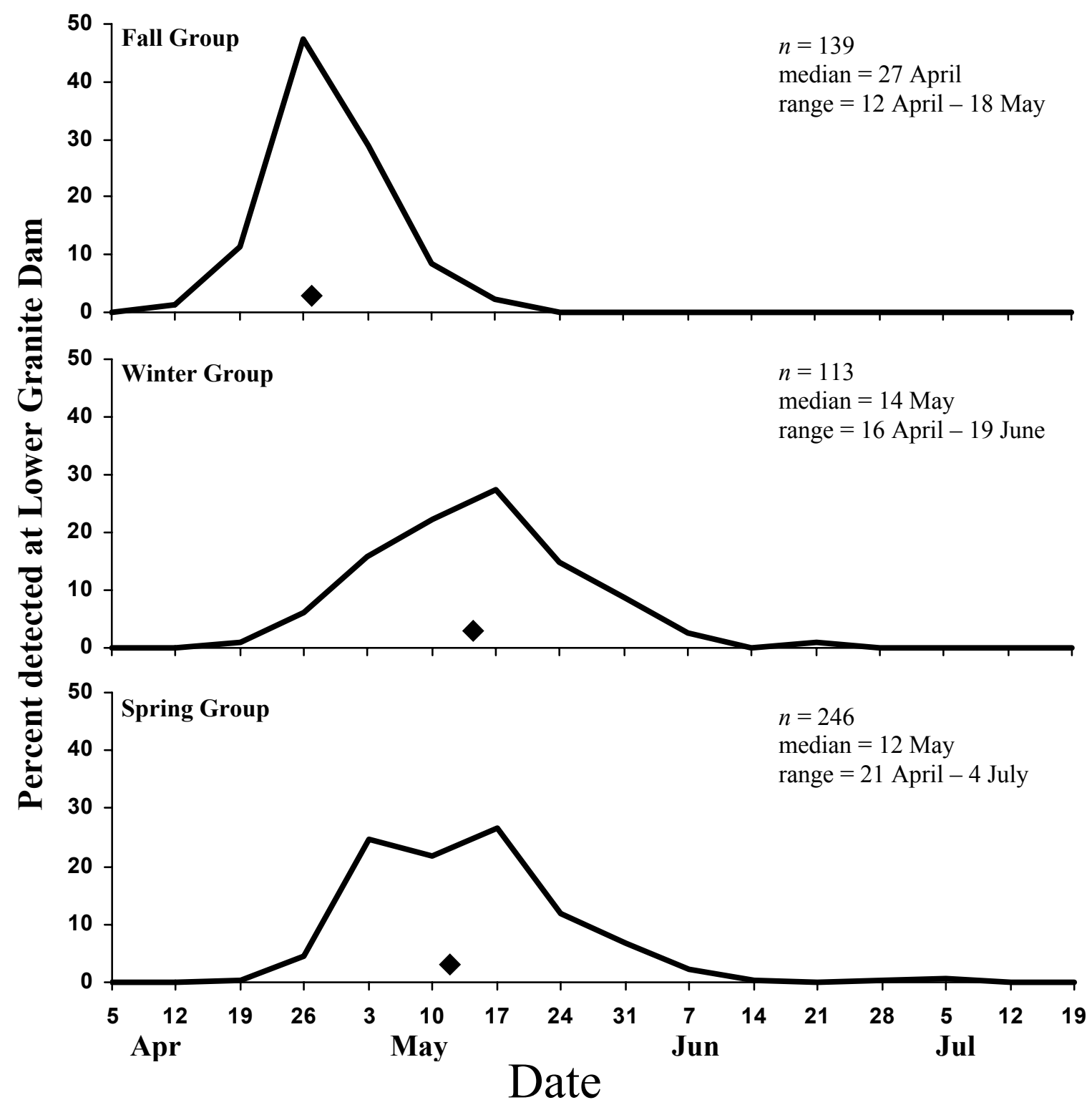

Figure 10. Dates of detection in 2001 at Lower Granite Dam for the fall, winter, and spring tag groups of juvenile spring chinook salmon PIT-tagged on the Lostine River, expressed as a percentage of the total detected for each group. $\bullet=$ median arrival date. Detections were expanded for spillway flow. 


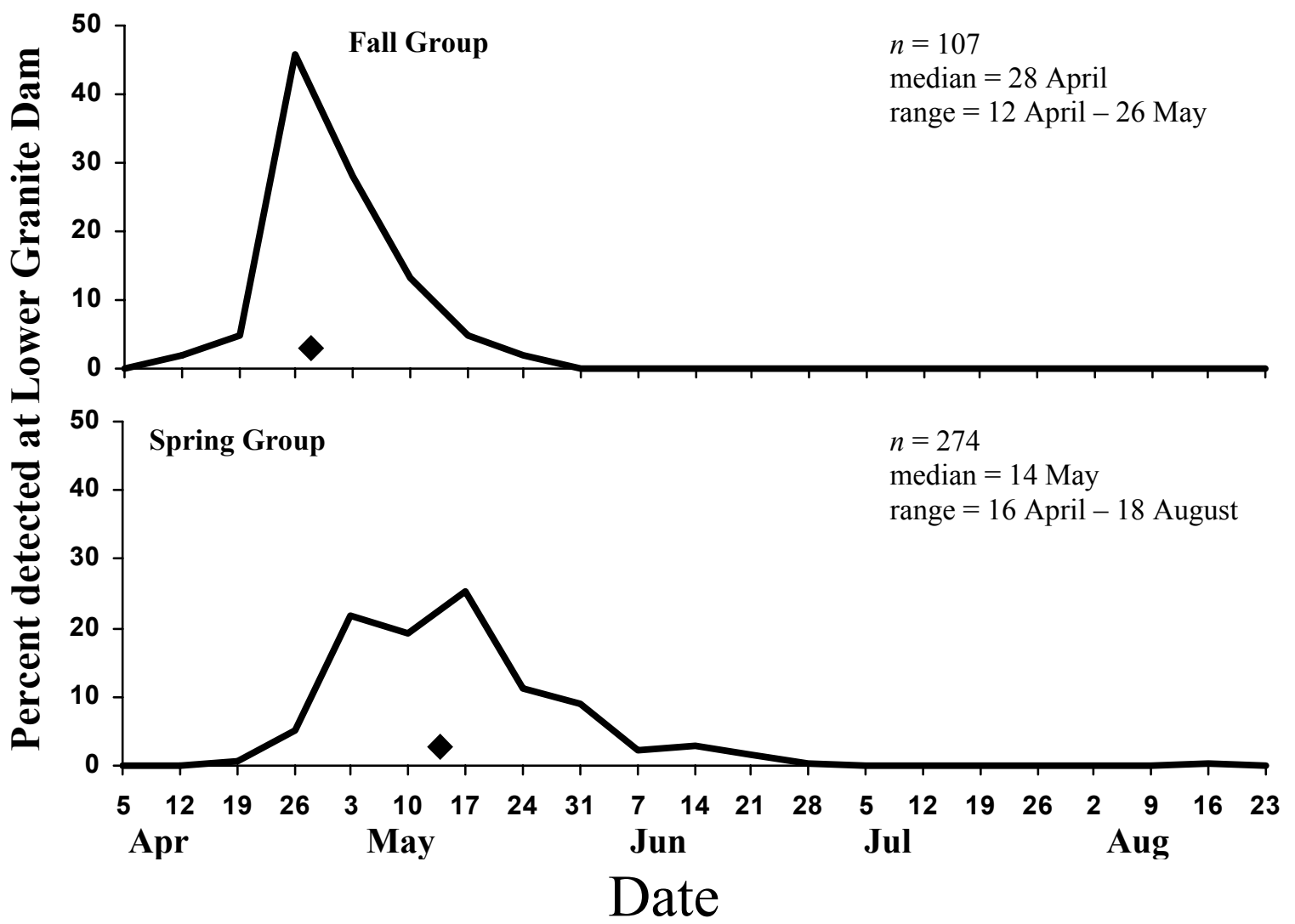

Figure 11. Dates of detection in 2001 at Lower Granite Dam for fall and spring tag groups of juvenile spring chinook salmon PIT-tagged on the Minam River, expressed as a percentage of the total detected for each group. - median arrival date. Detections were expanded for spillway flow. 


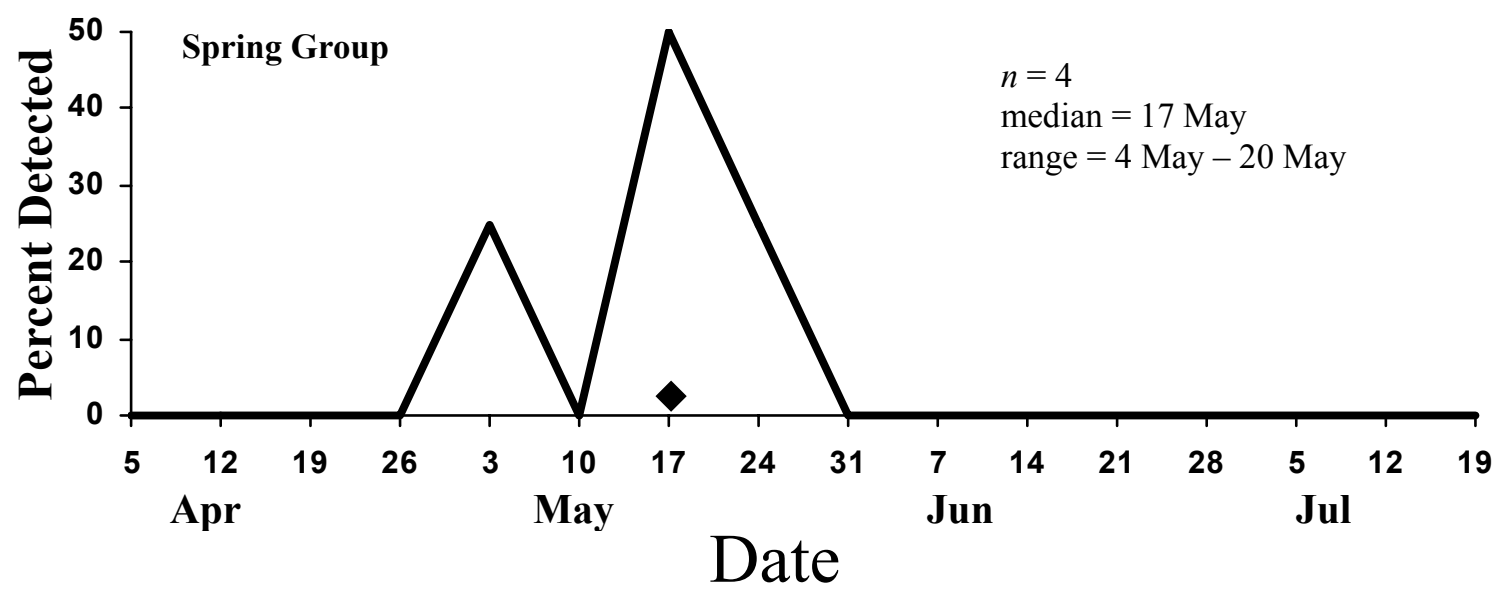

Figure 12. Dates of detection in 2001 at Lower Granite Dam for the spring tag group of juvenile spring chinook salmon PIT-tagged on the upper Grande Ronde River, expressed as a percentage of the total detected. = median arrival date. Detections were expanded for spillway flow. 


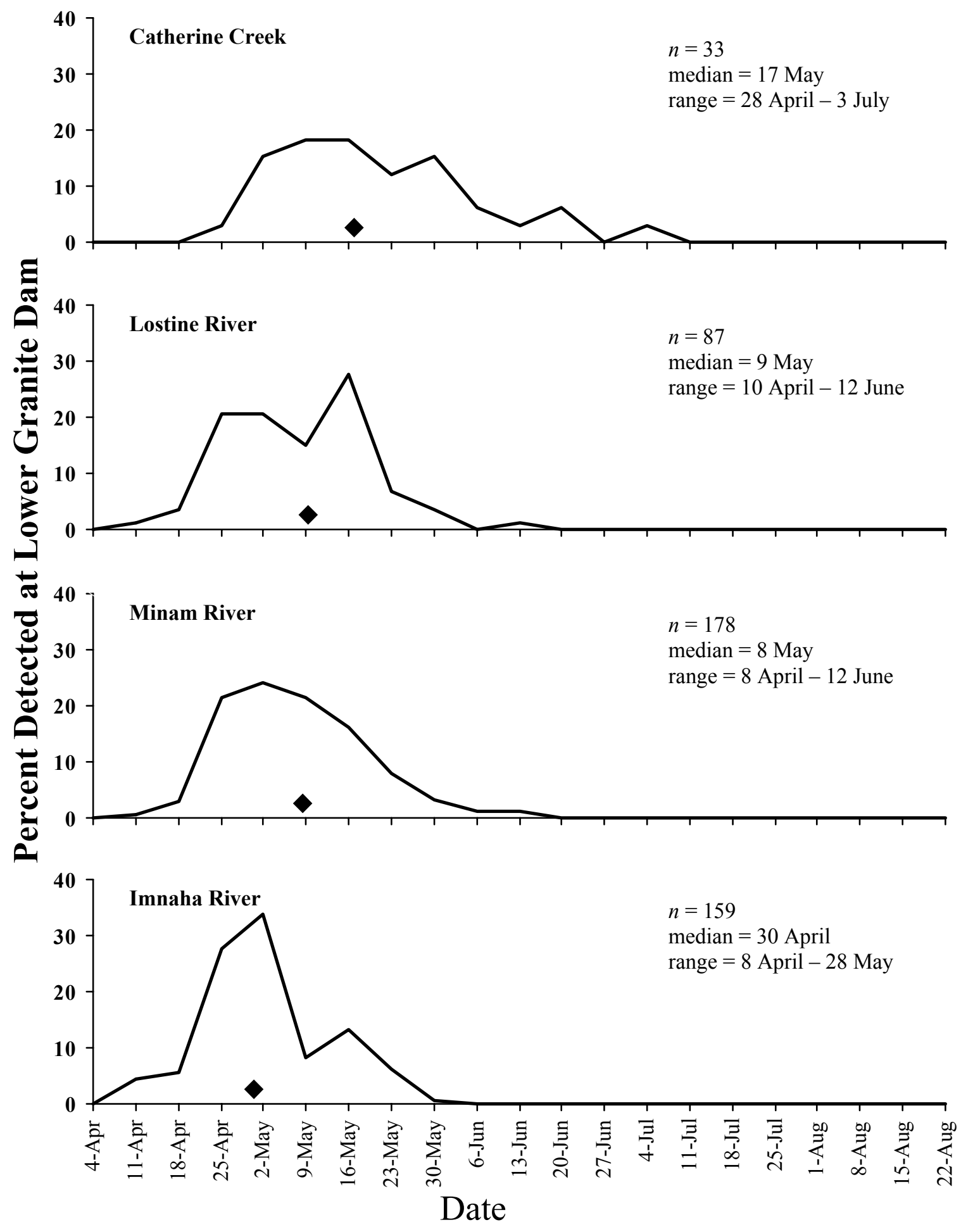

Figure 13. Dates of detection in 2001 at Lower Granite Dam of spring chinook salmon PITtagged as parr on Catherine Creek and the Imnaha, Lostine, and Minam rivers during the summer of 2000, summarized by week and expressed as a percentage of the total detected for each group. $\checkmark=$ median arrival date. No spill occurred on the dates of fish detection, so numbers were not adjusted. 

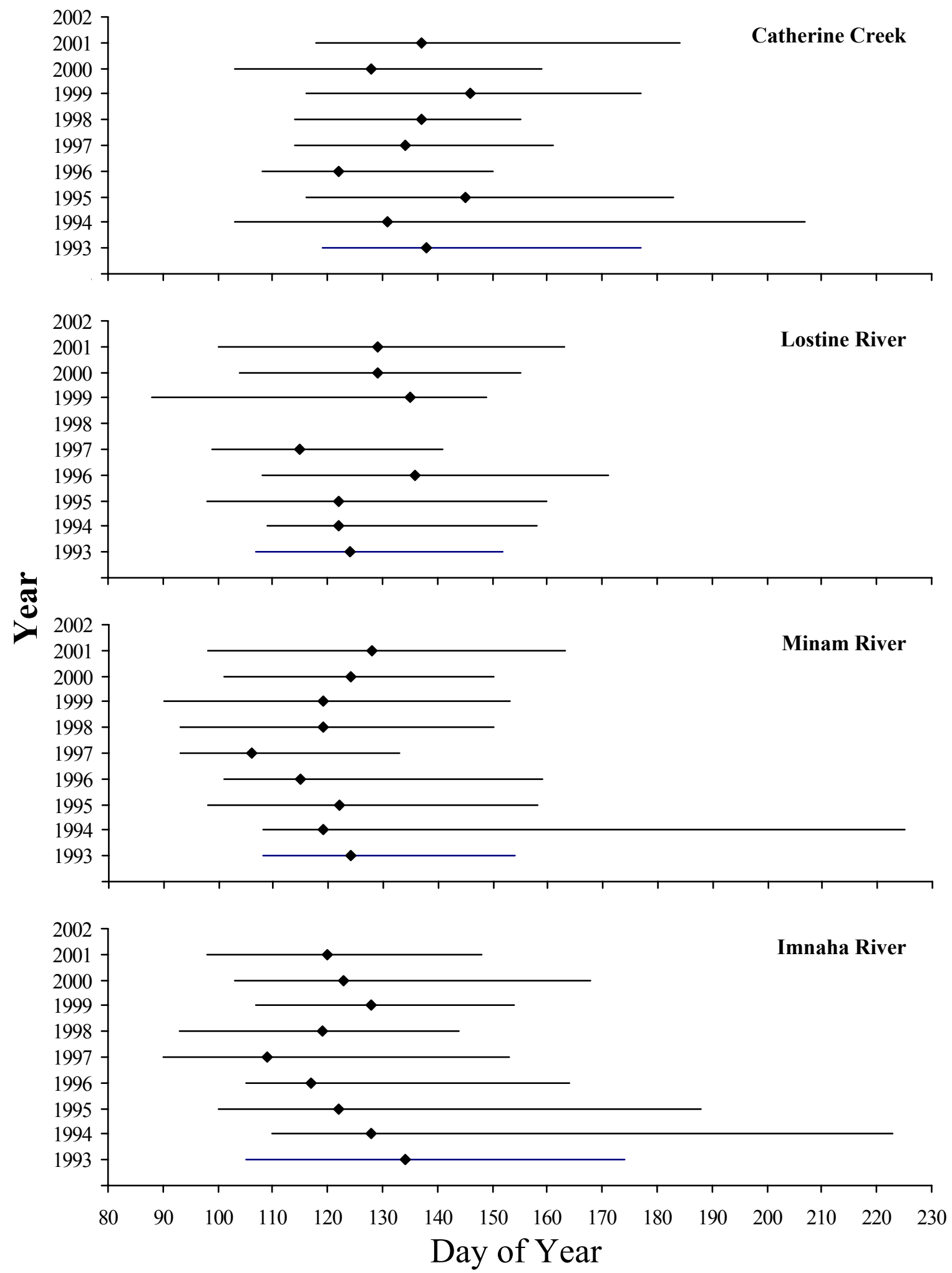

Figure 14. Median (diamonds) and first and last (bars) detection dates at Lower Granite Dam for wild chinook smolts tagged as parr during the summer in Catherine Creek, Lostine, Minam, and the Imnaha rivers, for migratory years 1993-2001. 


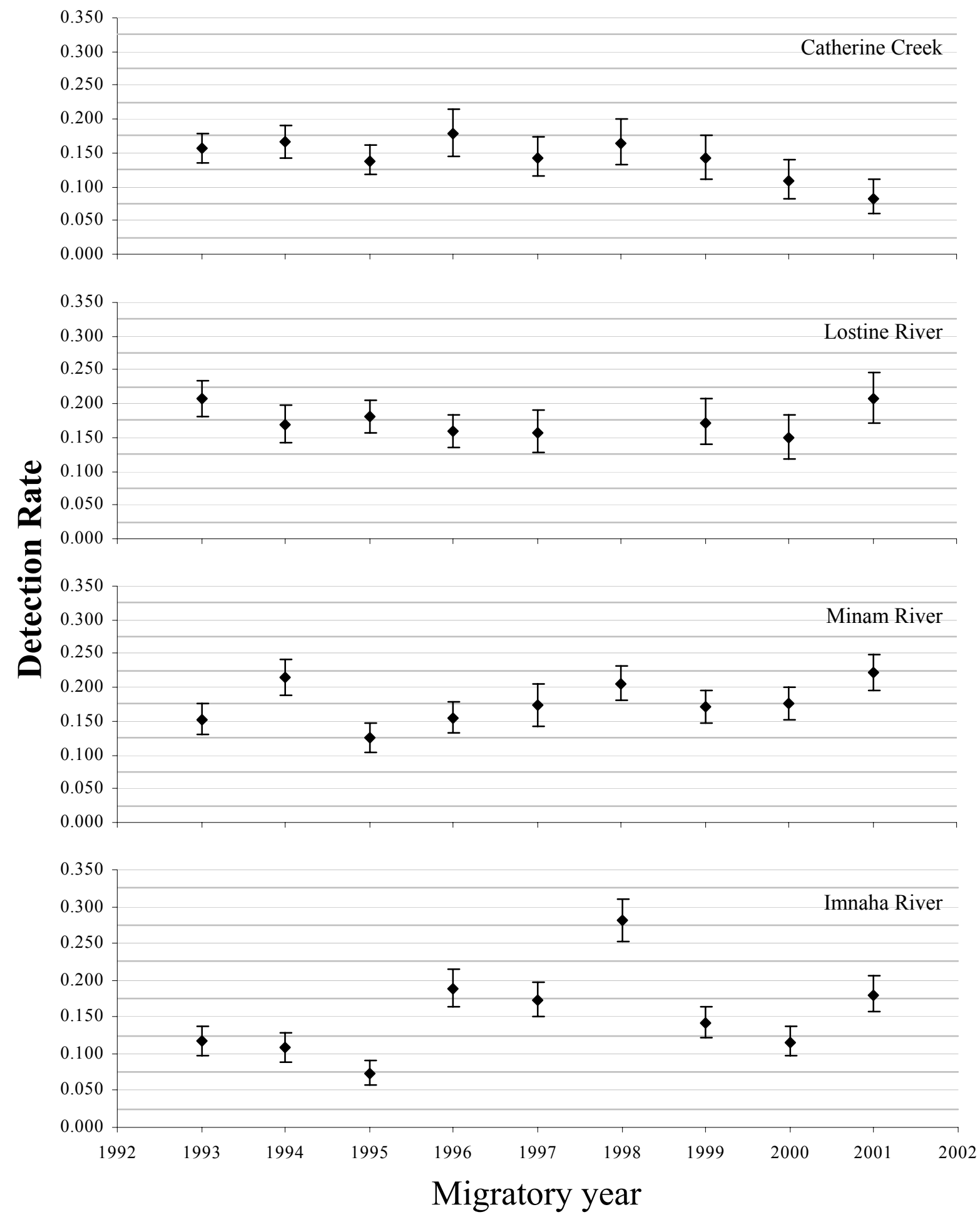

Figure 15. Dam detection rates and 95\% CI for spring chinook salmon parr PIT-tagged during the summer in Catherine Creek and the Lostine, Minam, and Imnaha rivers, for migratory years 1993-2001. 

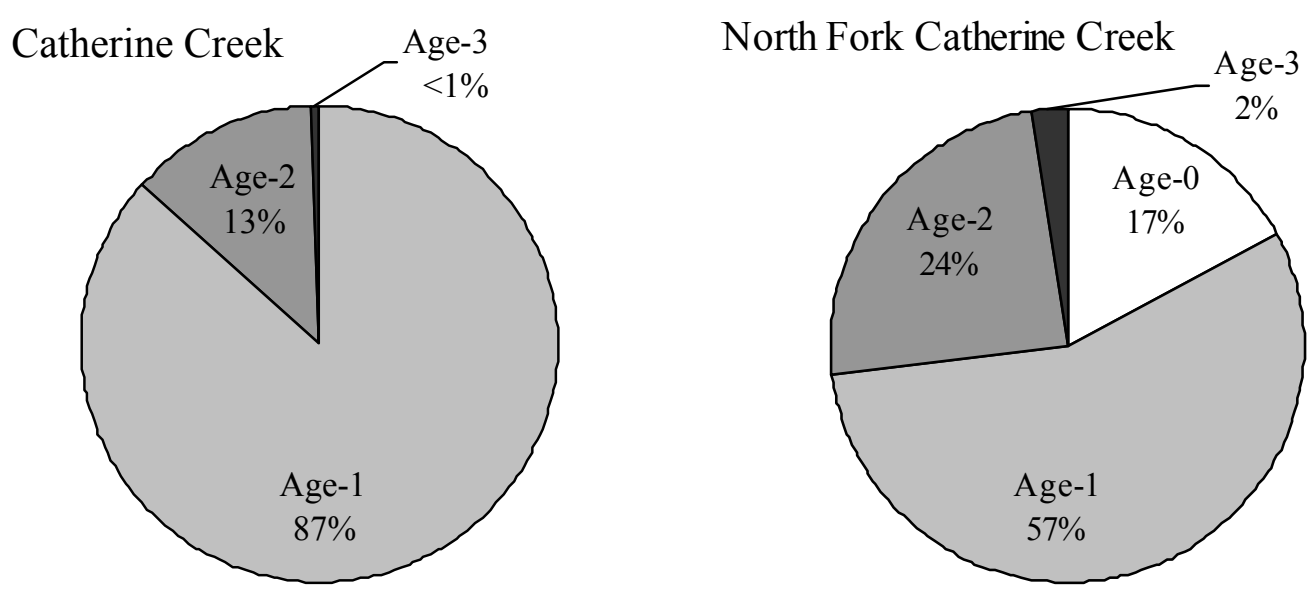

Figure 16. Age composition of the O. mykiss populations in Catherine Creek and North Fork Catherine Creek during early summer 2001. Age was determined by scale analysis. 


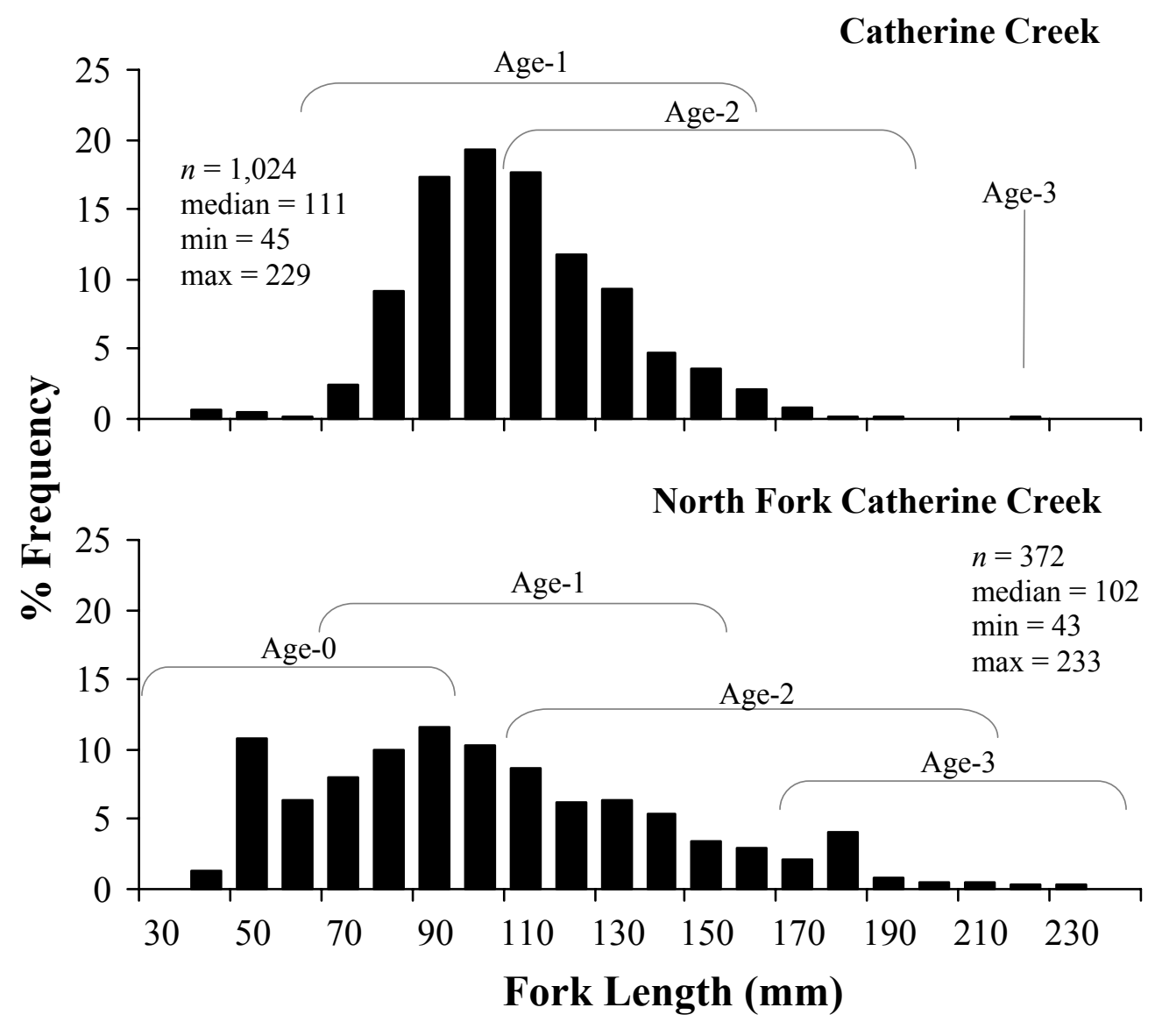

Figure 17. Fork lengths of $O$. mykiss in Catherine Creek and North Fork Catherine Creek measured during the summer of 2001. Frequencies are expressed as a percent of the total number measured $(n)$ on each stream. The ranges of lengths associated with each age class are shown in addition to the median, minimum, and maximum lengths of O.mykiss measured. 


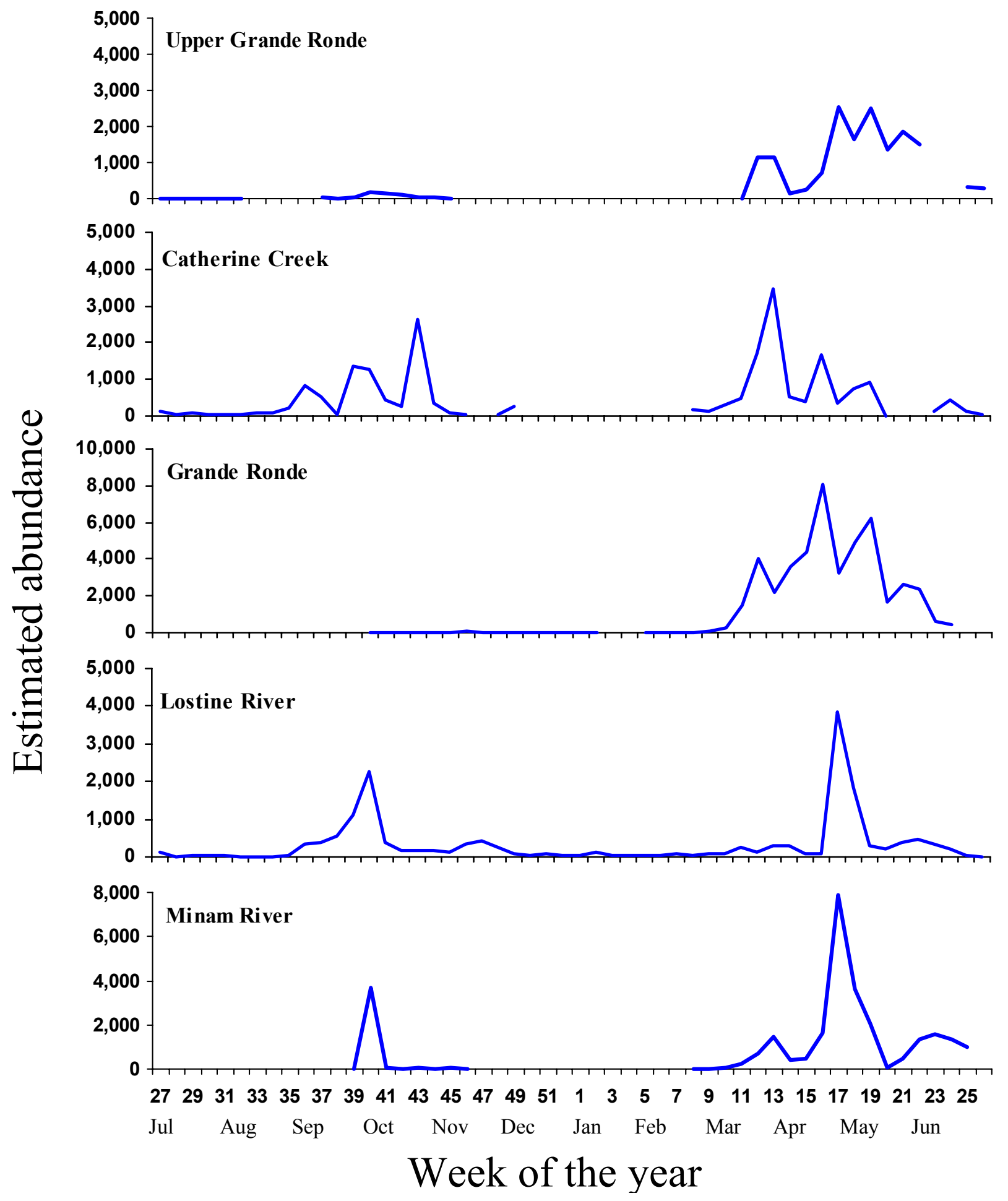

Figure 18. Estimated abundance and migration timing of $O$. mykiss migrants captured by rotary screw traps, during migratory year 2001. Traps were located at rkm 299 and 164 of the Grande Ronde River, rkm 32 of Catherine Creek, rkm 3 of the Lostine River, and rkm 0 of the Minam River. 


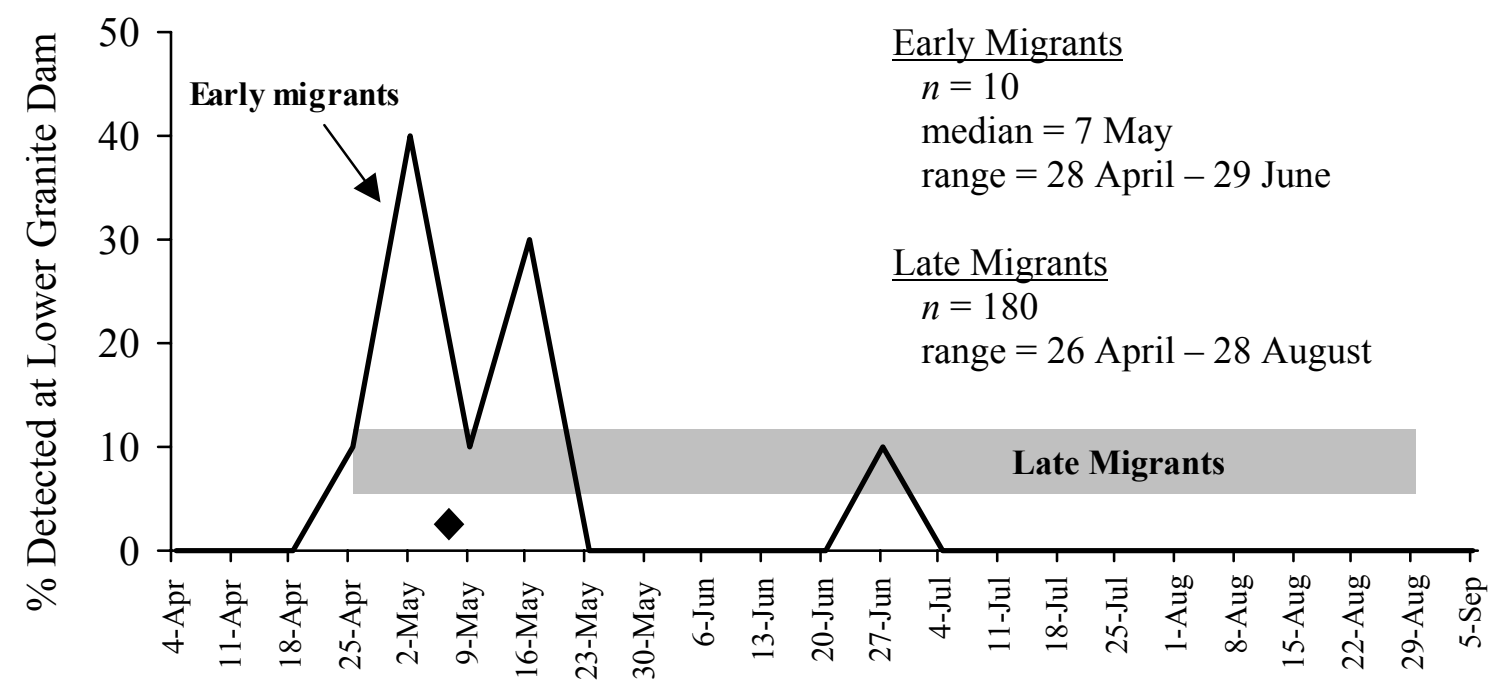

\section{Date}

Figure 19. Migration timing by tag group of $O$. mykiss PIT-tagged on the upper Grande Ronde River and subsequently detected at Lower Granite Dam during the 2001 migratory year. $\bullet=$ median detection date. Detection numbers were expanded for spillway flow. Shaded area shows range of migration timing by late migrant tag group. Median detection date was not calculated because tagging was not proportional to migration past the screw trap, and thus may not represent migration timing of the population. 


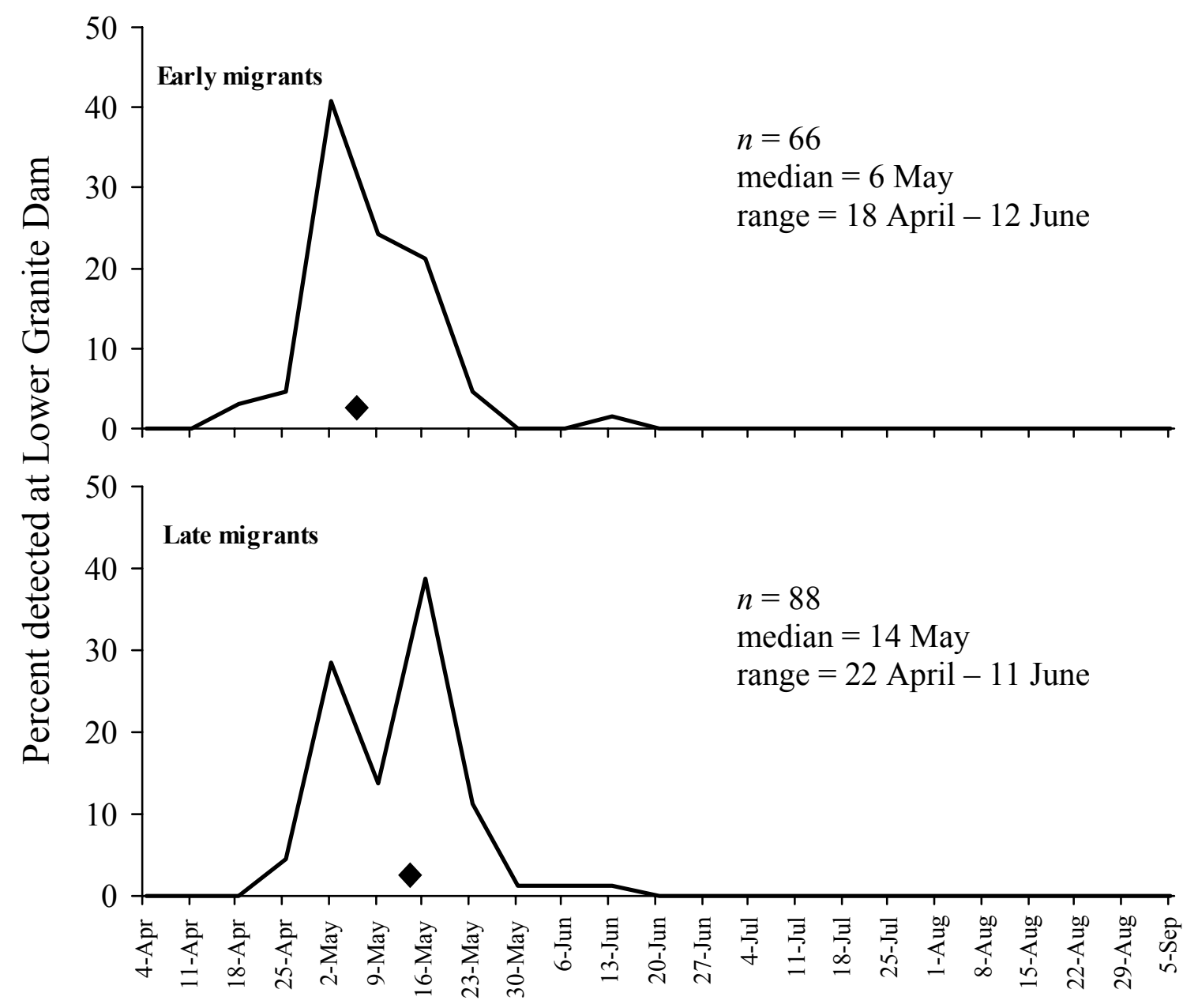

Date

Figure 20. Migration timing by tag group of $O$. mykiss PIT-tagged on Catherine Creek and subsequently detected at Lower Granite Dam during migratory year 2001 $\bullet=$ median detection date. Detection numbers were expanded for spillway flow. 


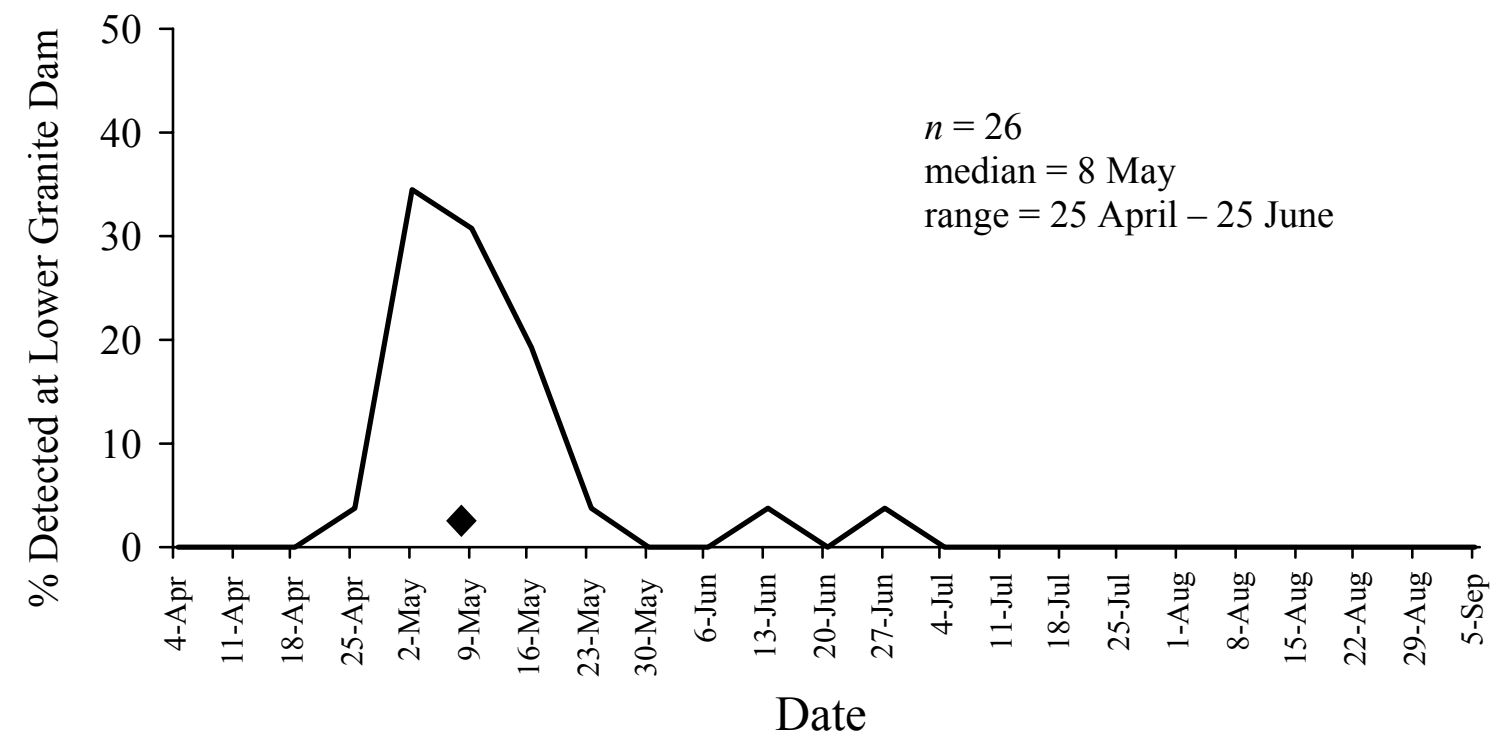

Figure 21. Dates of detection in 2001 at Lower Granite Dam of O. mykiss PIT-tagged as parr on Catherine Creek, North Fork Catherine Creek, and South Fork Catherine Creek during the summer of 2000 . $\$$ median detection date. Detection numbers were expanded for spillway flow. 


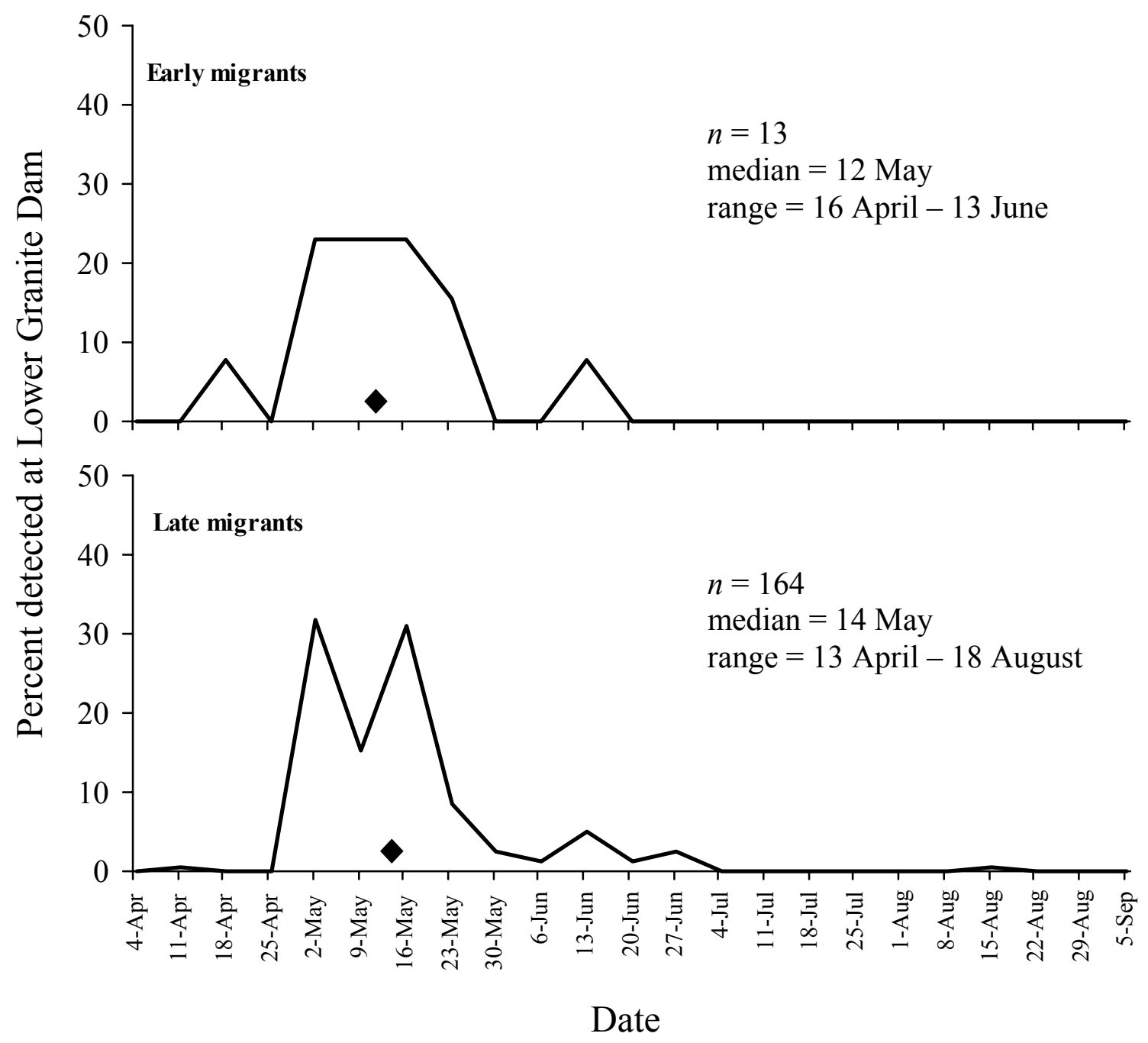

Figure 22. Migration timing by tag group of $O$. mykiss PIT-tagged on the Lostine River and subsequently detected at Lower Granite Dam during the 2001 migratory year. $\bullet=$ median detection date. Detection numbers were expanded for spillway flow. 


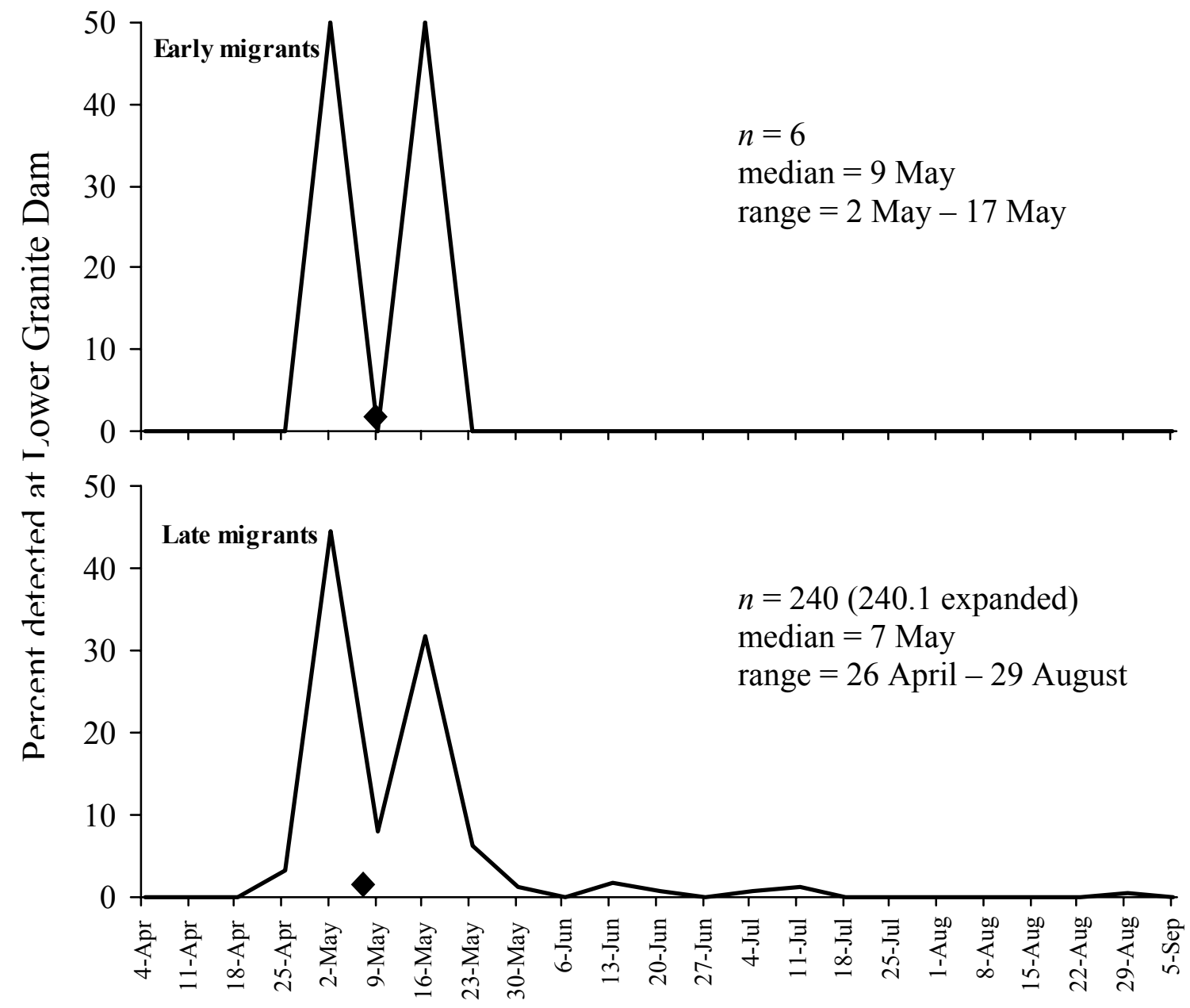

Date

Figure 23. Migration timing by tag group of $O$. mykiss PIT-tagged on the Minam River and subsequently detected at Lower Granite Dam during the 2001 migratory year. $\bullet=$ median detection date. Detection numbers were expanded for spillway flow. 

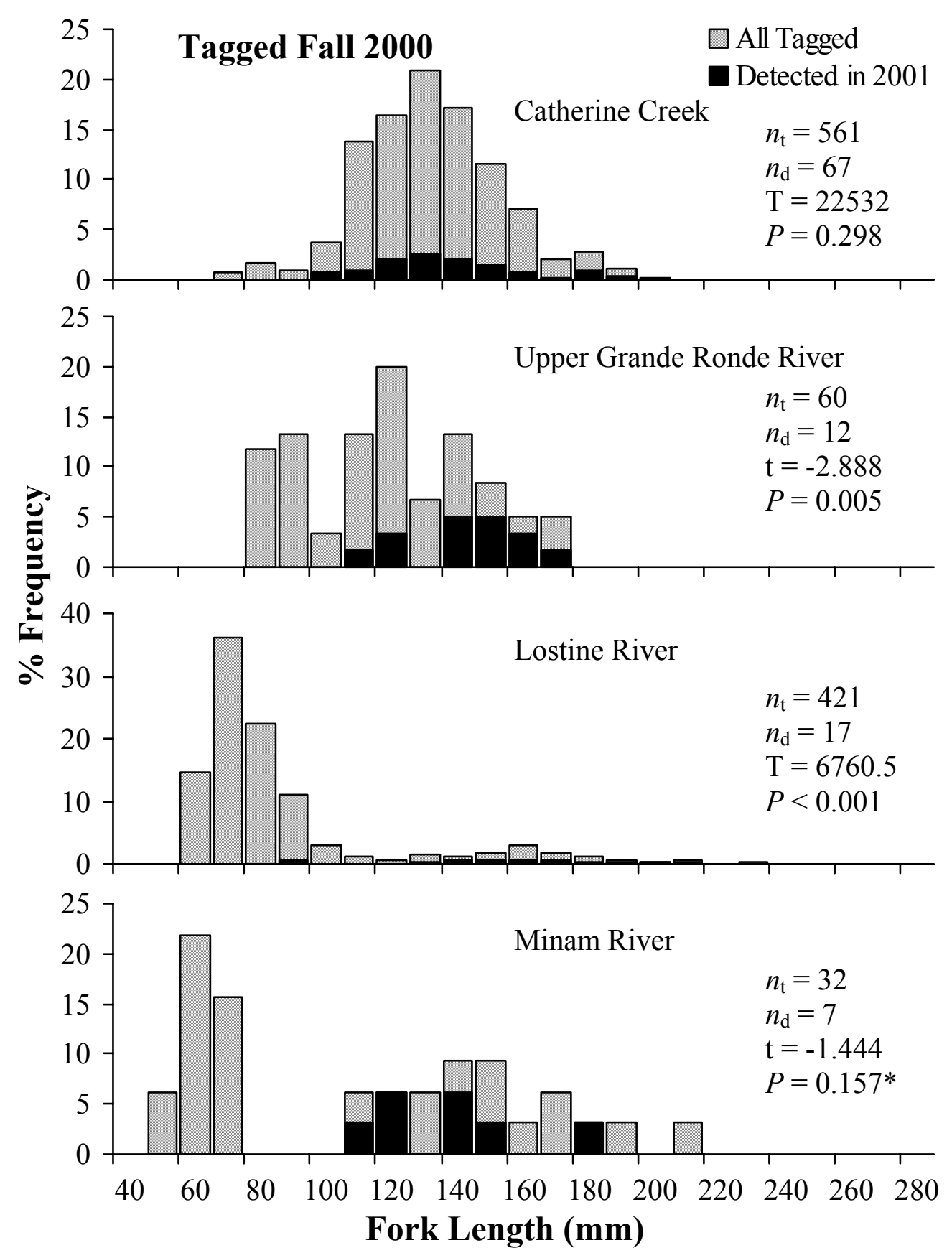

Figure 24. Fork lengths of all O. mykiss PIT-tagged at screw traps on Catherine Creek and the upper Grande Ronde, Lostine, and Minam rivers in the fall of 2000 and detected at Snake River or Columbia River dams in 2001 compared to lengths of all O. mykiss in the same tag group. Frequency is expressed as the percent of the total number tagged $\left(n_{\mathrm{t}}\right)$. ' $n_{\mathrm{d}}$ ' is the number detected, ' $T$ ' is test statistic for the Mann-Whitney Rank Sum Test, ' $t$ ' is the test statistic for the t-test, ' $P$ ' is the p-value associated with the rank sum or t-test. * Power of the t-test is $<0.80$ at $\alpha=0.05$. 


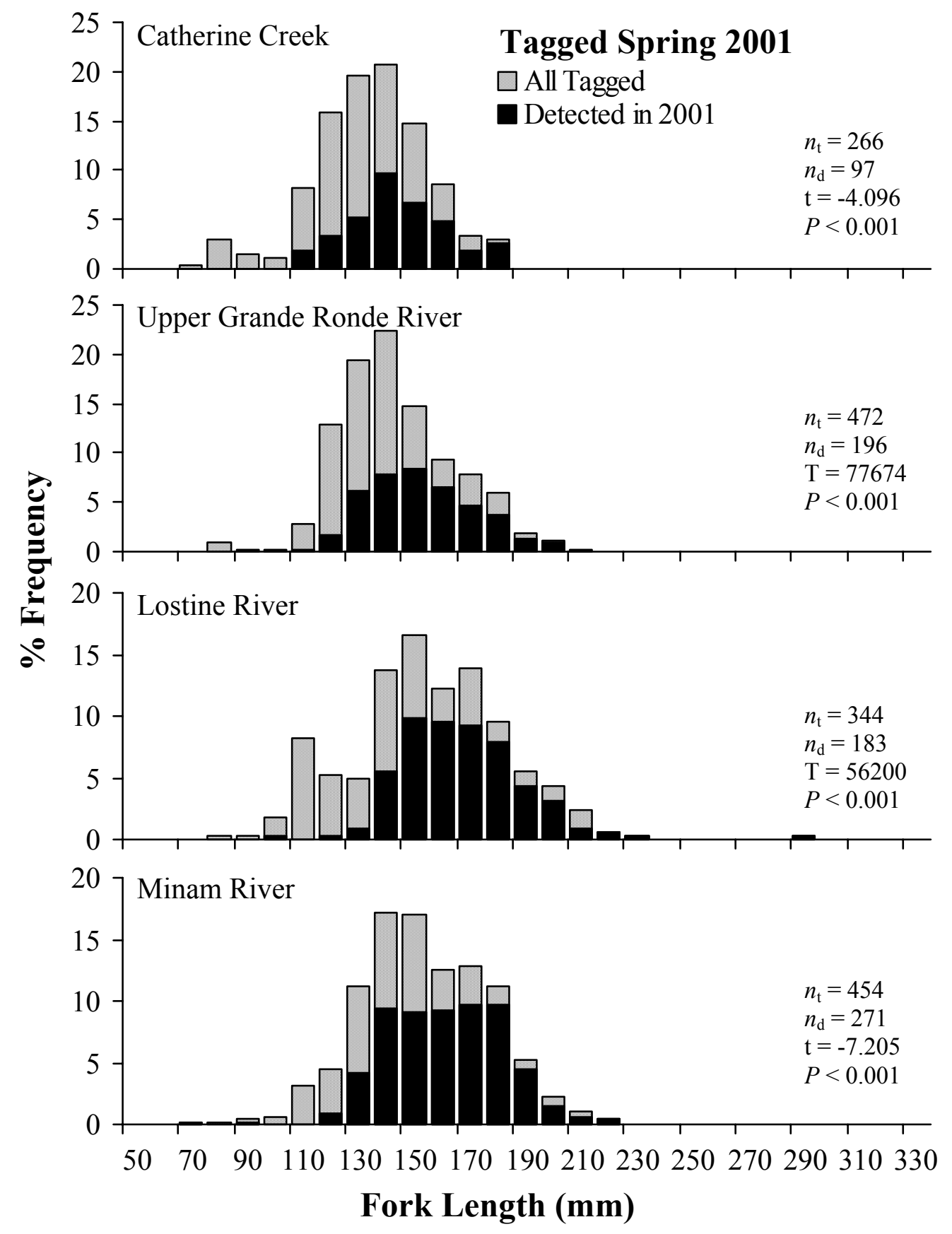

Figure 25. Fork lengths of all O. mykiss PIT-tagged at screw traps on Catherine Creek and the upper Grande Ronde, Lostine, and Minam rivers in the spring of 2001 and detected at Snake River or Columbia River dams in 2001 compared to lengths of all O. mykiss in the same tag group. Frequency is expressed as the percent of the total number tagged $\left(n_{\mathrm{t}}\right)$. ' $n_{\mathrm{d}}$ ' is the number detected, ' $T$ ' is test statistic for the Mann-Whitney Rank Sum Test, ' $t$ ' is the test statistic for the t-test, ' $P$ ' is the p-value associated with the rank sum or t-test. 


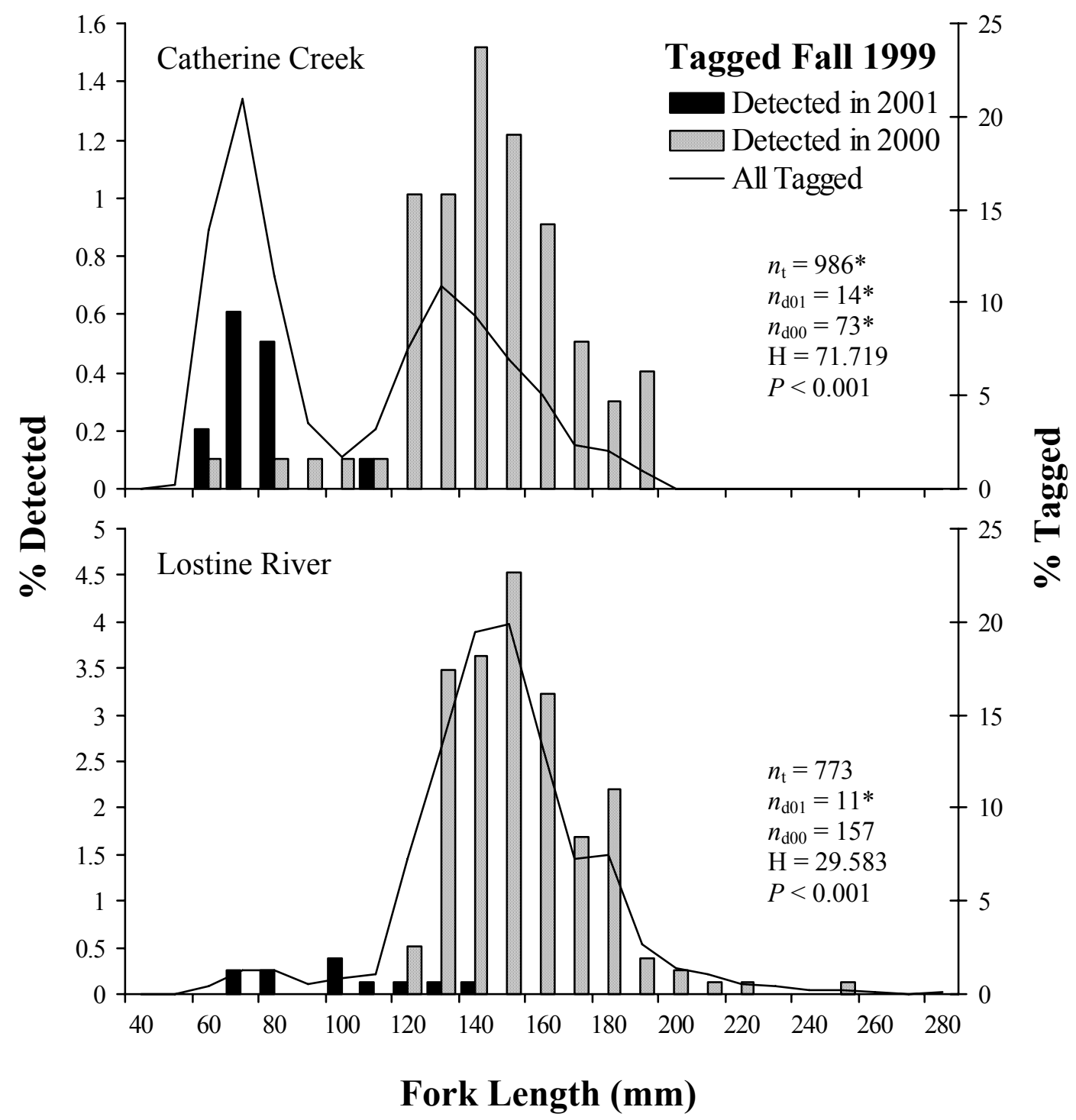

Figure 26. Lengths at time of tagging of $O$. mykiss that were PIT-tagged at Catherine Creek and Lostine River screw traps during the fall of $1999(\mathrm{t})$, lengths of those also detected at the dams in 2001 (d01), and lengths of those also detected at the dams in 2000 (d00). Frequency is expressed as the percent of the total number tagged. ' $\mathrm{H}$ ' is the test statistic for the Kruskal-Wallis one-way ANOVA on ranks of the lengths. ' $P$ ' is the p-value associated with the ANOVA.

* Median length of the group was significantly different $(\alpha=0.05$, Dunn's all pair-wise multiple comparison procedure). 


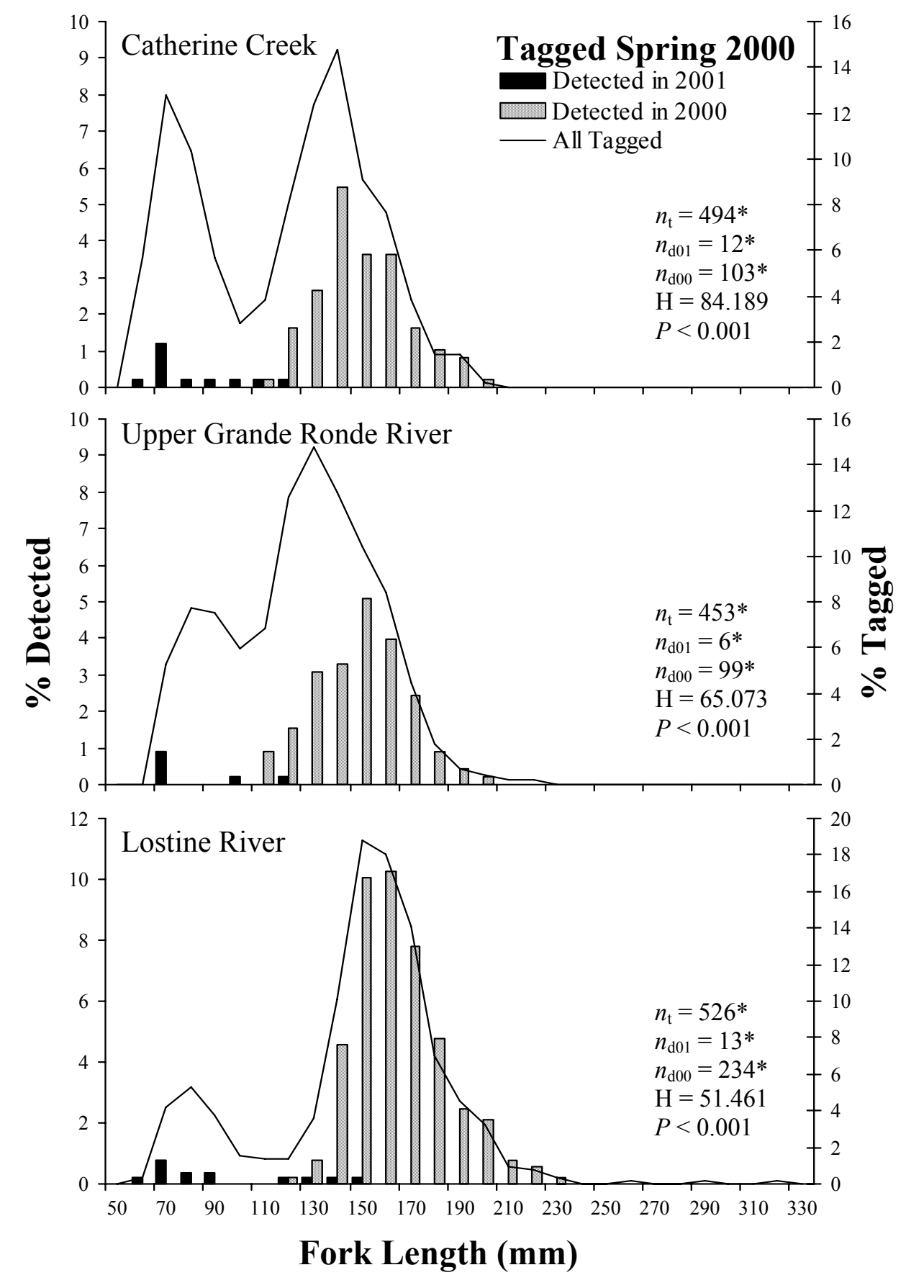

Figure 27. Lengths at time of tagging of $O$. mykiss that were tagged at Catherine Creek and upper Grande Ronde and Lostine River screw traps during the spring of $2000(\mathrm{t})$, lengths of those also detected at the dams in 2001 (d01), and lengths of those also detected at the dams in 2000 (d00). Frequency is expressed as the percent of the total number tagged. ' $\mathrm{H}$ ' is the test statistic for the Kruskal-Wallis one-way ANOVA on ranks of the lengths. ' $P$ ' is the p-value associated with the ANOVA. * Median length of the group was significantly different $(\alpha=0.05$, Dunn's all pair-wise multiple comparison procedure). 


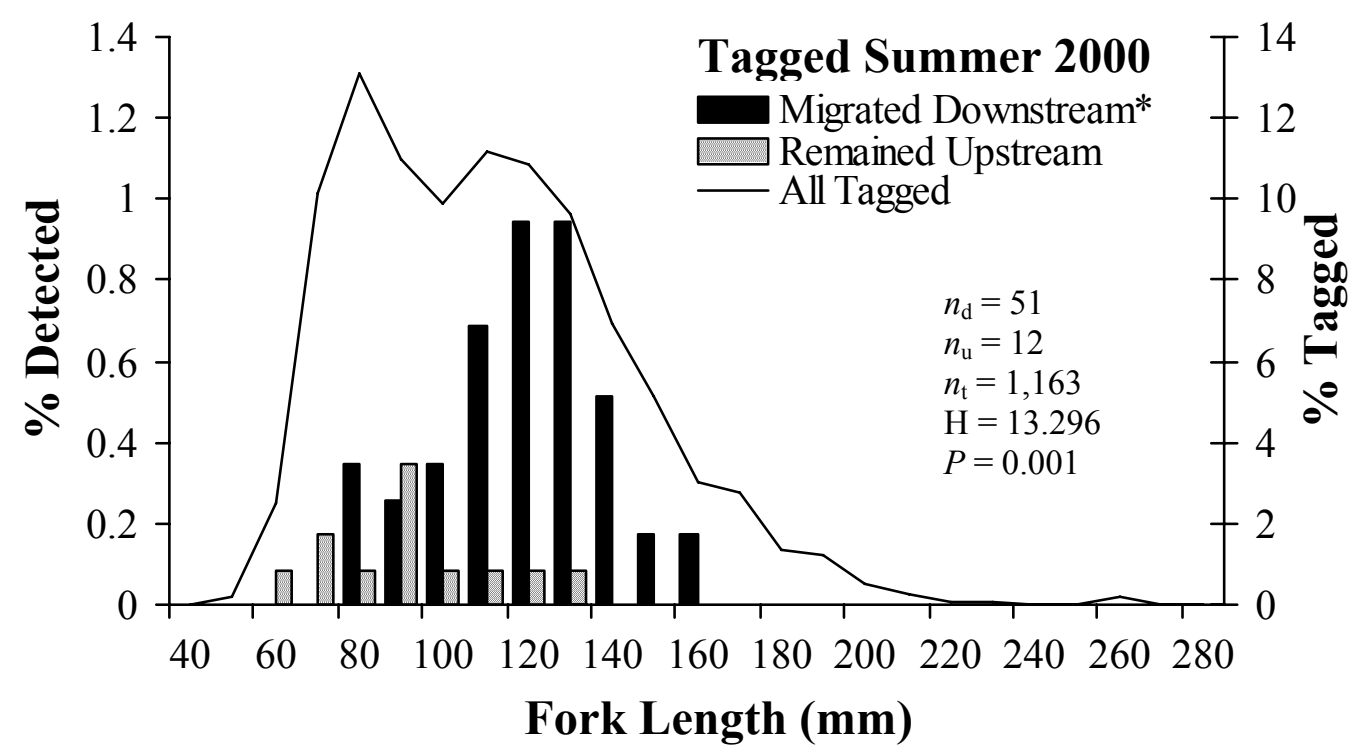

Figure 28. Lengths of $O$. mykiss that were tagged upstream of the screw trap on Catherine Creek during the summer $2000(\mathrm{t})$, lengths of those migrating downstream from upper rearing habitats by late spring 2001 (d), and lengths of those known to remain upstream through summer 2001 (u). Frequency is expressed as the percent of the total number tagged. ' $H$ ' is the test statistic for the Kruskal-Wallis one-way ANOVA on ranks of the lengths. ' $P$ ' is the p-value associated with the ANOVA. * Median length was significantly different $(\alpha=0.05$, Dunn's all pair-wise multiple comparison procedure).

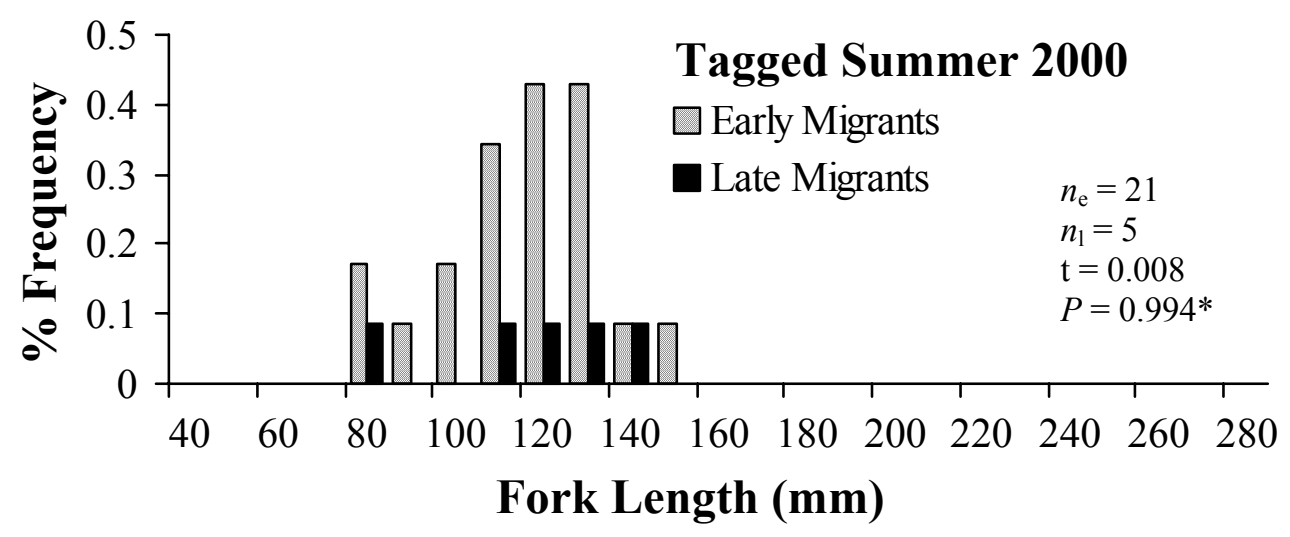

Figure 29. Lengths at tagging of $O$. mykiss that were tagged upstream of the screw trap on Catherine Creek during the summer of 2000 and recaptured at the screw trap in the fall of 2000 (early migrants) and the spring of 2001 (late migrants). Frequency is expressed as the percent of the total number tagged $(1,163)$. ' $n_{\mathrm{e}}$ ' is the number of fall migrants, ' $n_{1}$ ' is the number of spring migrants, ' $\mathrm{t}$ ' is the test statistic for the t-test, ' $P$ ' is the p-value associated with the $\mathrm{t}$-test. * Power $<0.80$. 


\section{APPENDIX A}

A Compilation of Spring Chinook Salmon Data 
Appendix Table A-1. Ages of immature and mature, wild spring chinook salmon parr collected in summer rearing areas of Catherine Creek, and the Lostine, Minam, and Imnaha rivers, 1998 2001. Ages were determined by analysis of scales collected from a random subsample of fish caught for PIT-tagging.

\begin{tabular}{|c|c|c|c|c|c|c|}
\hline \multirow[b]{2}{*}{ Stream, year } & \multicolumn{3}{|c|}{ Immature parr } & \multicolumn{3}{|c|}{ Mature parr } \\
\hline & Age-0 & Age-1 & $\%$ Age- 0 & Age-0 & Age-1 & $\%$ Age- 1 \\
\hline \multicolumn{7}{|c|}{ Catherine Creek: } \\
\hline 1998 & 208 & 0 & 100.0 & 0 & 113 & 100.0 \\
\hline 1999 & 204 & 0 & 100.0 & 1 & 209 & 99.5 \\
\hline 2000 & 258 & $3^{\mathrm{a}}$ & 98.9 & 0 & 106 & 100.0 \\
\hline 2001 & - & - & - & 0 & 103 & 100.0 \\
\hline \multicolumn{7}{|l|}{ Lostine River: } \\
\hline 1998 & 231 & 0 & 100.0 & 0 & 20 & 100.0 \\
\hline 1999 & 201 & 0 & 100.0 & 0 & 23 & 100.0 \\
\hline 2000 & 110 & 0 & 100.0 & 0 & 31 & 100.0 \\
\hline 2001 & - & - & - & 1 & 3 & $75.0^{\mathrm{b}}$ \\
\hline \multicolumn{7}{|l|}{ Minam River: } \\
\hline 1998 & - & - & - & 0 & 1 & $100.0^{\mathrm{b}}$ \\
\hline 1999 & - & - & - & - & - & - \\
\hline 2000 & 70 & 0 & 100.0 & - & - & - \\
\hline 2001 & 212 & 0 & 100.0 & 0 & 4 & $100.0^{\mathrm{b}}$ \\
\hline \multicolumn{7}{|l|}{ Imnaha River: } \\
\hline 1998 & - & - & - & 0 & 3 & $100.0^{\mathrm{b}}$ \\
\hline 1999 & - & - & - & - & - & - \\
\hline 2000 & - & - & - & - & - & - \\
\hline 2001 & 67 & 0 & 100.0 & - & - & - \\
\hline
\end{tabular}

a These parr were collected in early August and it is possible that they were on their way to maturing precociously but their maturity characteristics had not yet developed (see Monzyk et al. 2000).

b Note small sample size. 
Appendix Table A-2. Dates of tagging and number of spring chinook salmon parr PIT-tagged on various northeast Oregon streams, 1998-2001.

\begin{tabular}{|c|c|c|c|}
\hline Year, stream & $\begin{array}{c}\text { Dates of } \\
\text { collection and tagging }\end{array}$ & $\begin{array}{c}\text { Number tagged } \\
\text { and released }\end{array}$ & $\begin{array}{l}\text { Distance to Lower } \\
\text { Granite Dam }(\mathrm{km}) \\
\end{array}$ \\
\hline \multicolumn{4}{|l|}{ 1998: } \\
\hline Catherine Creek & 3-7 August & 502 & $354-375$ \\
\hline Lostine River & 10-13 August & 506 & $274-302$ \\
\hline Minam River & 17-19 August & 1,006 & $280-284$ \\
\hline Imnaha River & 24-26 August & 1,009 & $237-243$ \\
\hline \multicolumn{4}{|l|}{ 1999: } \\
\hline Catherine Creek & 2-5 August & 499 & $358-374$ \\
\hline Lostine River & 9-11 August & 509 & $277-301$ \\
\hline Minam River & 16-18 August & 998 & $279-283$ \\
\hline Imnaha River & 23-25 August & 982 & $208-241$ \\
\hline \multicolumn{4}{|l|}{ 2000: } \\
\hline Catherine Creek & 7-10 August & 500 & $370-377$ \\
\hline Lostine River & 14-17 August & 490 & $276-290$ \\
\hline Minam River & 22 August, 18-19 September & 1,000 & $282-283$ \\
\hline Imnaha River & 28-30 August & 1,000 & $222-243$ \\
\hline \multicolumn{4}{|l|}{ 2001: } \\
\hline Catherine Creek & 30 July - 2 August & 503 & $363-382$ \\
\hline Lostine River & 6-9 August & 501 & $275-301$ \\
\hline Minam River & 20-23 August & 996 & $282-284$ \\
\hline Imnaha River & 27-28 August & 1,001 & $208-240$ \\
\hline
\end{tabular}


Appendix Table A-3. Spring chinook salmon parr mark-recapture population estimates on Catherine Creek and the Lostine River during summer, 1998-2001. All fish were captured by snorkel-seining.

\begin{tabular}{|c|c|c|c|c|c|c|}
\hline \multirow[b]{2}{*}{$\begin{array}{l}\text { Stream, } \\
\quad \text { parr maturity, origin }\end{array}$} & \multirow[b]{2}{*}{ Year } & \multicolumn{3}{|c|}{ Census data } & \multirow[b]{2}{*}{$\begin{array}{c}\text { Population } \\
\text { estimate }(\mathrm{N})\end{array}$} & \multirow[b]{2}{*}{$95 \% \mathrm{CI}$} \\
\hline & & Marked (M) & $\begin{array}{l}\text { Recaptured } \\
\text { (R) }\end{array}$ & Captured (C) & & \\
\hline \multicolumn{7}{|l|}{ Catherine Creek: } \\
\hline \multirow[t]{4}{*}{ Immature, wild } & 1998 & 1,050 & 49 & 628 & 13,222 & $10,047-17,819$ \\
\hline & 1999 & 1,003 & 52 & 1,187 & 22,505 & $17,239-29,341$ \\
\hline & 2000 & 1,262 & 47 & 987 & 25,997 & $19,651-35,151$ \\
\hline & 2001 & 1,325 & 121 & 1,382 & 15,032 & $12,598-17,931$ \\
\hline \multirow[t]{4}{*}{ Mature, wild } & 1998 & 73 & 9 & 57 & 429 & $237-858$ \\
\hline & 1999 & 117 & 21 & 136 & 735 & $490-1,155$ \\
\hline & 2000 & 123 & 14 & 87 & 727 & $445-1,254$ \\
\hline & 2001 & 111 & 9 & 87 & 986 & $545-1,971$ \\
\hline Mature, hatchery & 2000 & 18 & 5 & 11 & 38 & $18-88$ \\
\hline \multicolumn{7}{|l|}{ Lostine River: } \\
\hline \multirow{4}{*}{ Immature, wild } & 1998 & 1,010 & 22 & 926 & 40,748 & $27,403-63,324$ \\
\hline & 1999 & 1,000 & 17 & 504 & 28,084 & $17,926-46,377$ \\
\hline & 2000 & 974 & 89 & 1,141 & 12,372 & $10,075-15,185$ \\
\hline & 2001 & 1,074 & 62 & 1,938 & 33,086 & $25,901-42,226$ \\
\hline \multirow[t]{4}{*}{ Mature, wild } & 1998 & 14 & 1 & 9 & $75^{\mathrm{a}}$ & $23-136$ \\
\hline & 1999 & 10 & 0 & 15 & $176^{\mathrm{a}}$ & - \\
\hline & 2000 & 35 & 3 & 32 & $297^{\mathrm{a}}$ & $121-743$ \\
\hline & 2001 & 5 & 0 & 1 & $12^{\mathrm{a}}$ & - \\
\hline
\end{tabular}

a Population estimate is biased because $R$ is not greater than or equal to 3 or Mx C is not greater than $4 N$. 
Appendix Table A-4. Number of spring chinook salmon parr and number of parr produced per redd in Catherine Creek and the Lostine River during summer, by brood year, age, and maturity. Number of parr by maturity and age were calculated using markrecapture population estimates and age ratios for immature and mature parr determined by scale analysis.

\begin{tabular}{|c|c|c|c|c|c|c|c|}
\hline \multirow[b]{2}{*}{ Stream, brood year } & \multirow[b]{2}{*}{ Redds } & \multicolumn{3}{|c|}{ Number of age-0 parr } & \multicolumn{3}{|c|}{ Number of age-1 parr } \\
\hline & & Immature & Mature & Parr/redd & Immature & Mature & Parr/redd \\
\hline \multicolumn{8}{|l|}{ Catherine Creek } \\
\hline 1996 & 15 & - & - & - & 0 & 429 & 29 \\
\hline 1997 & 46 & 13,222 & 0 & 287 & 0 & 731 & 16 \\
\hline 1998 & 34 & 22,505 & 4 & 662 & 299 & 703 & 29 \\
\hline 1999 & 38 & 25,698 & 0 & 676 & 0 & 986 & 26 \\
\hline 2000 & 26 & 15,032 & 0 & 578 & - & - & - \\
\hline \multicolumn{8}{|l|}{ Lostine River } \\
\hline 1996 & 27 & - & - & - & 0 & (a) & 0 \\
\hline 1997 & 47 & 40,748 & (a) & 867 & 0 & (a) & 0 \\
\hline 1998 & 28 & 28,084 & (a) & 1,003 & 0 & 297 & 11 \\
\hline 1999 & 45 & 12,372 & 0 & 275 & 0 & (a) & 0 \\
\hline 2000 & 53 & 33,086 & (a) & 624 & - & - & - \\
\hline
\end{tabular}

a Too few mature parr were captured for population estimate. 
Appendix Table A-5. Proportion of immature age- 0 spring chinook salmon parr from one summer that remain in freshwater and mature by the next summer, and number of mature male parr present in relation to the number of redds counted.

\begin{tabular}{|c|c|c|c|c|}
\hline \multirow[b]{2}{*}{ Stream, year } & \multirow{2}{*}{$\begin{array}{l}\text { Estimated } \\
\text { mature } \\
\text { parr }^{\mathrm{a}}\end{array}$} & \multirow{2}{*}{$\begin{array}{c}\text { Percentage of immature } \\
\text { parr from previous summer } \\
\text { maturing at age- } 1\end{array}$} & \multicolumn{2}{|c|}{$\begin{array}{l}\text { Potential for mature male parr } \\
\text { to spawn with wild adult females }\end{array}$} \\
\hline & & & Redds $^{b}$ & Mature parr /redd \\
\hline \multicolumn{5}{|c|}{ Catherine Creek: } \\
\hline 1998 & 429 & - & 34 & 12.6 \\
\hline 1999 & 735 & 5.5 & 38 & 19.3 \\
\hline 2000 & 703 & 3.2 & 26 & 27.0 \\
\hline 2001 & 986 & 3.8 & 131 & 7.5 \\
\hline \multicolumn{5}{|l|}{ Lostine River: } \\
\hline 1998 & (c) & - & 28 & (c) \\
\hline 1999 & (c) & (c) & 45 & (c) \\
\hline 2000 & 297 & 1.1 & 53 & 5.6 \\
\hline 2001 & $(\mathrm{c})$ & (c) & 98 & (c) \\
\hline
\end{tabular}

a Mark-recapture estimates.

${ }^{\mathrm{b}}$ Redd information from ODFW spawning ground surveys.

c Too few mature parr captured to estimate the population size. 
Appendix Table A-6. Dates of detection at Lower Granite Dam of spring chinook salmon smolts PIT-tagged at screw traps as early and late migrants and during the winter. Parentheses indicate that median might be biased and reflect when fish were tagged. Numbers of fish detected were expanded for spillway flow.

\begin{tabular}{|c|c|c|c|c|c|c|c|}
\hline \multirow[b]{2}{*}{$\begin{array}{l}\text { Stream, } \\
\text { migratory year }\end{array}$} & \multirow[b]{2}{*}{$\begin{array}{l}\text { Tag } \\
\text { group }\end{array}$} & \multirow[b]{2}{*}{$\begin{array}{l}\text { Migrant } \\
\text { group }\end{array}$} & \multirow[b]{2}{*}{$\begin{array}{c}\text { Number } \\
\text { tagged }\end{array}$} & \multirow[b]{2}{*}{$\begin{array}{l}\text { Number } \\
\text { detected }\end{array}$} & \multicolumn{3}{|c|}{ Detection dates } \\
\hline & & & & & Median & First & Last \\
\hline \multicolumn{8}{|l|}{ Catherine Creek: } \\
\hline \multirow[t]{3}{*}{2000} & Fall & Early & 677 & 56 & $05 / 03$ & $04 / 12$ & $05 / 29$ \\
\hline & Winter & Late & 500 & 22 & $05 / 09$ & $04 / 25$ & $06 / 01$ \\
\hline & Spring & Late & 431 & 52 & $(05 / 12)$ & $04 / 21$ & $07 / 02$ \\
\hline \multirow[t]{3}{*}{2001} & Fall & Early & 494 & 57 & $05 / 10$ & $04 / 27$ & $06 / 18$ \\
\hline & Winter & Late & 538 & 27 & $06 / 01$ & $05 / 04$ & $07 / 06$ \\
\hline & Spring & Late & 329 & 100 & $(05 / 30)$ & $04 / 29$ & $07 / 13$ \\
\hline
\end{tabular}

Upper Grande Ronde River:

\begin{tabular}{lllccccc}
2000 & Fall & Early & 493 & 45 & $05 / 08$ & $04 / 12$ & $06 / 06$ \\
& Winter & Late & 500 & 22 & $05 / 26$ & $05 / 09$ & $07 / 16$ \\
& Spring & Late & 495 & 91 & $(05 / 11)$ & $04 / 15$ & $07 / 20$ \\
2001 & & & & & & & \\
& Spring & Late & 6 & 4 & $(05 / 17)$ & $05 / 04$ & $05 / 20$ \\
\multirow{2}{*}{$\begin{array}{l}20 \text { tine River: } \\
2000\end{array}$} & & & & & & & \\
& Fall & Early & 514 & 59 & $04 / 18$ & $04 / 03$ & $05 / 13$ \\
& Winter & Late & 511 & 51 & $05 / 09$ & $04 / 20$ & $07 / 02$ \\
& Spring & Late & 355 & 65 & $(05 / 22)$ & $04 / 14$ & $7 / 16$ \\
2001 & & & & & & & \\
& Fall & Early & 500 & 139 & $04 / 27$ & $04 / 12$ & $05 / 18$ \\
& Winter & Late & 500 & 113 & $05 / 14$ & $04 / 16$ & $06 / 19$ \\
& Spring & Late & 445 & 246 & $(05 / 12)$ & $04 / 21$ & $07 / 04$
\end{tabular}

Minam River:

2001

Fall

Early $\quad 300$

300

107

$04 / 28 \quad 04 / 12 \quad 05 / 26$

Spring

Late

539

274

$\begin{array}{lll}05 / 14) & 04 / 16 \quad 08 / 18\end{array}$ 
Appendix Table A-7. Travel time to Lower Granite Dam of juvenile spring chinook salmon PITtagged at upstream screw traps in the spring and arriving at Lower Granite Dam the same year. Bold mean indicates normal distribution of travel times. Bold median indicates non-normal distribution.

\begin{tabular}{|c|c|c|c|c|}
\hline \multirow[b]{2}{*}{ Stream, migratory year } & \multirow{2}{*}{$\begin{array}{l}\text { Number } \\
\text { detected }\end{array}$} & \multicolumn{3}{|c|}{ Travel time (days) } \\
\hline & & Mean & Median & Range \\
\hline \multicolumn{5}{|l|}{ Catherine Creek: } \\
\hline 2000 & 52 & 53.9 & 50.5 & $20-95$ \\
\hline 2001 & 100 & 63.7 & 64.5 & $15-110$ \\
\hline \multicolumn{5}{|c|}{ Upper Grande Ronde River: } \\
\hline 2000 & 91 & 49.7 & 50.5 & $12-98$ \\
\hline 2001 & 4 & 39.9 & 37.5 & $29-56$ \\
\hline \multicolumn{5}{|l|}{ Lostine River: } \\
\hline 2000 & 65 & 33.6 & 32.5 & $5-90$ \\
\hline 2001 & 246 & 26.1 & 23.6 & $5-90$ \\
\hline \multicolumn{5}{|l|}{ Minam River: } \\
\hline 2001 & 274 & 38.9 & 39.5 & $9-106$ \\
\hline
\end{tabular}


Appendix Table A-8. Detection rates of juvenile spring chinook salmon PIT-tagged on the upper Grande Ronde River, Catherine Creek, and the Lostine, Minam, and Imnaha rivers by tag group and dam site during the 2001 migratory year. Detection rates are presented as a percentage of the total fish tagged and released. Numbers of fish detected are in parentheses.

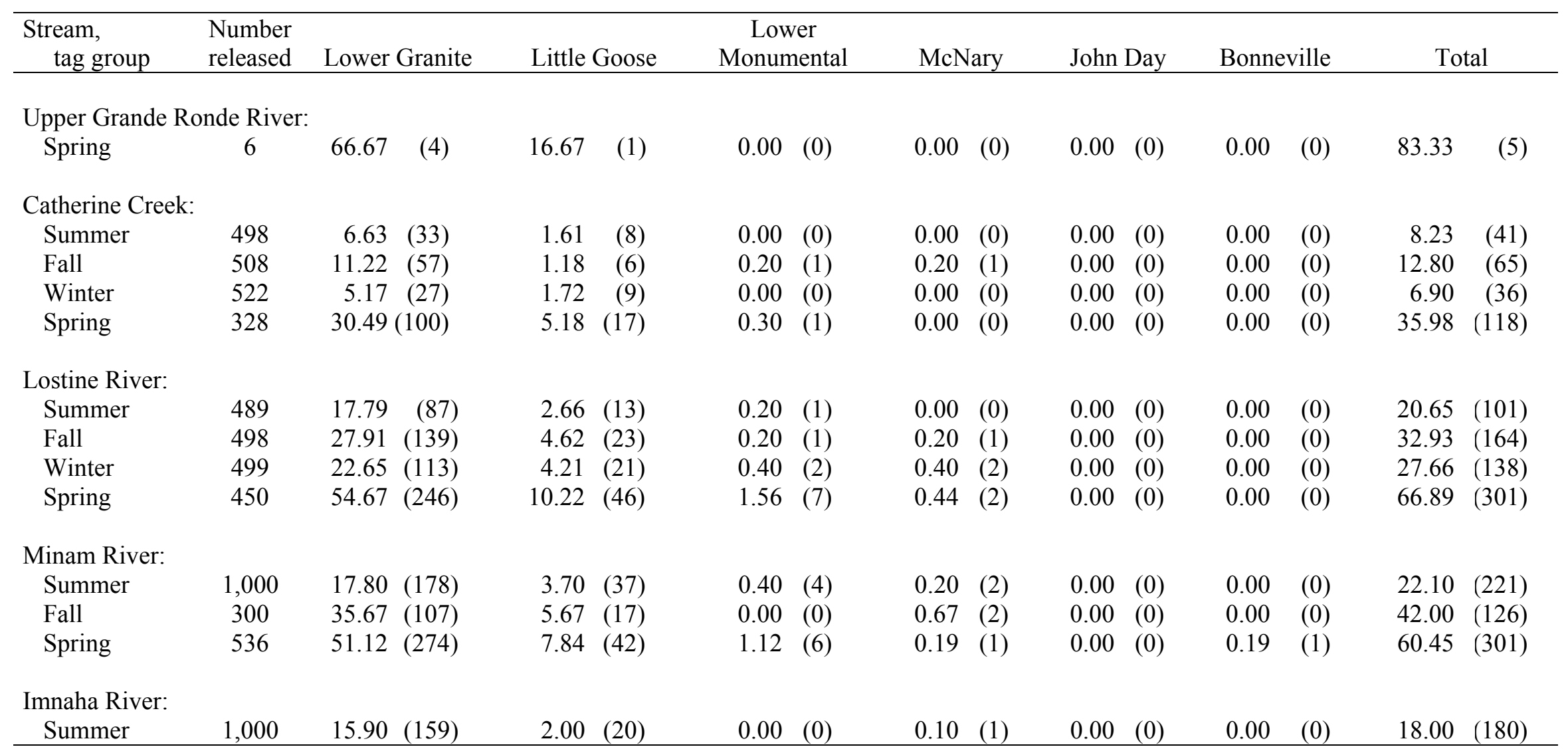


Appendix Table A-9. PIT tag detection rates, CJS survival probabilities, and numbers of fish tagged and detected for juvenile spring chinook salmon by stream, 1993-2001 migratory years.

\begin{tabular}{|c|c|c|c|c|c|c|c|}
\hline \multirow{2}{*}{$\begin{array}{l}\text { Stream, } \\
\text { migratory year }\end{array}$} & \multirow[b]{2}{*}{ Tag group } & \multirow[b]{2}{*}{$\begin{array}{c}\text { Number } \\
\text { tagged }\end{array}$} & \multirow[b]{2}{*}{$\begin{array}{l}\text { Number } \\
\text { detected }\end{array}$} & \multicolumn{2}{|c|}{ Detection rate } & \multicolumn{2}{|c|}{ CJS survival probability } \\
\hline & & & & Rate & $95 \% \mathrm{CI}$ & Probability & $95 \% \mathrm{CI}$ \\
\hline \multicolumn{8}{|c|}{ Catherine Creek: } \\
\hline 1993 & summer & 1,096 & 171 & 0.156 & $0.135-0.179$ & 0.178 & $0.151-0.212$ \\
\hline 1994 & summer & 1,000 & 166 & 0.166 & $0.143-0.191$ & 0.226 & $0.186-0.279$ \\
\hline 1995 & summer & 1,000 & 138 & 0.138 & $0.117-0.161$ & 0.154 & $0.129-0.184$ \\
\hline 1995 & fall & 502 & 100 & 0.199 & $0.165-0.237$ & 0.238 & $0.193-0.297$ \\
\hline 1995 & winter & 482 & 116 & 0.241 & $0.203-0.281$ & 0.279 & $0.230-0.343$ \\
\hline 1995 & spring & 348 & 157 & 0.451 & $0.398-0.505$ & 0.506 & $0.441-0.578$ \\
\hline 1996 & summer & 499 & 89 & 0.178 & $0.146-0.215$ & 0.277 & $0.205-0.406$ \\
\hline 1996 & summer(trap) & 102 & 14 & 0.137 & $0.077-0.220$ & 0.431 & $0.140-6.335$ \\
\hline 1996 & fall & 508 & 144 & 0.283 & $0.245-0.325$ & 0.358 & $0.296-0.446$ \\
\hline 1996 & winter & 295 & 40 & 0.136 & $0.099-0.180$ & 0.312 & $0.163-1.008$ \\
\hline 1996 & spring & 276 & 119 & 0.431 & $0.372-0.492$ & 0.591 & $0.480-0.755$ \\
\hline 1997 & summer & 585 & 84 & 0.144 & $0.116-0.175$ & 0.176 & $0.139-0.225$ \\
\hline 1997 & fall & 403 & 82 & 0.203 & $0.165-0.246$ & 0.365 & $0.256-0.588$ \\
\hline 1997 & winter & 102 & 7 & 0.069 & $0.028-0.136$ & 0.078 & $0.033-0.222$ \\
\hline 1997 & winter(trap) & 86 & 21 & 0.244 & $0.158-0.349$ & 0.302 & $0.187-0.597$ \\
\hline 1997 & spring & 78 & 29 & 0.372 & $0.265-0.489$ & 0.413 & $0.292-0.580$ \\
\hline 1998 & summer & 495 & 81 & 0.164 & $0.132-0.199$ & 0.211 & $0.164-0.276$ \\
\hline 1998 & summer(trap) & 175 & 31 & 0.177 & $0.124-0.242$ & 0.190 & $0.131-0.275$ \\
\hline 1998 & fall & 598 & 116 & 0.194 & $0.163-0.228$ & 0.238 & $0.194-0.293$ \\
\hline 1998 & winter & 438 & 101 & 0.231 & $0.192-0.273$ & 0.278 & $0.226-0.345$ \\
\hline 1998 & spring & 453 & 208 & 0.459 & $0.413-0.506$ & 0.517 & $0.459-0.583$ \\
\hline 1999 & summer & 502 & 71 & 0.141 & $0.112-0.175$ & 0.157 & $0.122-0.212$ \\
\hline 1999 & fall & 656 & 114 & 0.174 & $0.146-0.205$ & 0.202 & $0.166-0.250$ \\
\hline 1999 & winter & 494 & 116 & 0.235 & $0.198-0.275$ & 0.285 & $0.230-0.367$ \\
\hline 1999 & spring & 502 & 181 & 0.361 & $0.318-0.404$ & 0.448 & $0.379-0.545$ \\
\hline 2000 & summer & 497 & 54 & 0.109 & $0.083-0.139$ & 0.151 & $0.109-0.217$ \\
\hline 2000 & fall & 677 & 108 & 0.160 & $0.133-0.189$ & 0.212 & $0.170-0.269$ \\
\hline 2000 & winter & 500 & 56 & 0.112 & $0.086-0.143$ & 0.138 & $0.102-0.191$ \\
\hline 2000 & spring & 431 & 130 & 0.302 & $0.259-0.347$ & 0.452 & $0.359-0.598$ \\
\hline 2001 & summer & 498 & 41 & 0.082 & $0.060-0.110$ & 0.087 & $0.063-0.115$ \\
\hline 2001 & fall & 508 & 65 & 0.128 & $0.100-0.160$ & 0.130 & $0.103-0.162$ \\
\hline 2001 & winter & 522 & 36 & 0.069 & $0.049-0.094$ & 0.077 & $0.054-0.106$ \\
\hline 2001 & spring & 328 & 118 & 0.360 & $0.308-0.414$ & 0.376 & $0.322-0.433$ \\
\hline
\end{tabular}


Appendix Table A-9. Continued.

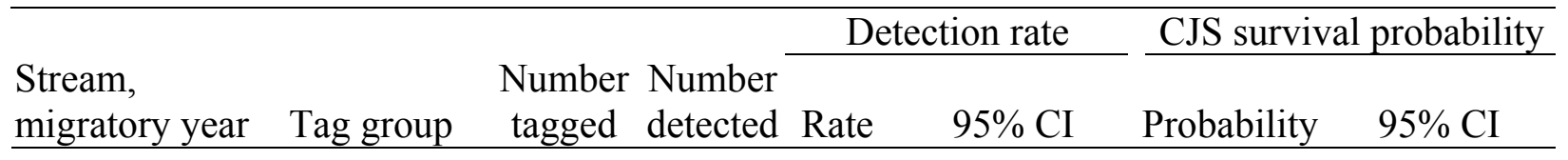

Upper Grande Ronde River:

\begin{tabular}{|c|c|c|c|c|c|c|c|}
\hline 1993 & summer & 921 & 204 & 0.221 & $0.195-0.250$ & 0.287 & $0.237-0.365$ \\
\hline 1994 & summer & 1,001 & 90 & 0.090 & $0.073-0.109$ & 0.144 & $0.110-0.197$ \\
\hline 1994 & fall & 405 & 110 & 0.272 & $0.229-0.318$ & 0.348 & $0.284-0.432$ \\
\hline 1994 & winter & 505 & 58 & 0.115 & $0.088-0.146$ & 0.248 & $0.152-0.519$ \\
\hline 1994 & spring & 573 & 189 & 0.330 & $0.291-0.370$ & 0.462 & $0.387-0.563$ \\
\hline 1995 & summer & 999 & 142 & 0.142 & $0.121-0.165$ & 0.173 & $0.144-0.209$ \\
\hline 1995 & fall & 424 & 87 & 0.205 & $0.168-0.247$ & 0.228 & $0.184-0.281$ \\
\hline 1995 & winter & 433 & 62 & 0.143 & $0.112-0.180$ & 0.151 & $0.115-0.199$ \\
\hline 1995 & spring & 368 & 204 & 0.554 & $0.502-0.606$ & 0.609 & $0.545-0.683$ \\
\hline 1996 & fall & 5 & 1 & 0.200 & $0.005-0.716$ & - & $-\quad \quad-$ \\
\hline 1996 & spring & 327 & 118 & 0.361 & $0.309-0.416$ & 0.512 & $0.404-0.690$ \\
\hline 1997 & fall & 27 & 4 & 0.148 & $0.042-0.337$ & - & $-\quad \quad-$ \\
\hline 1997 & spring & 1 & 1 & 1.000 & $0.500 \quad 1.000$ & - & - \\
\hline 1998 & fall & 592 & 150 & 0.253 & $0.219-0.290$ & 0.286 & $0.244-0.334$ \\
\hline 1998 & winter & 124 & 13 & 0.105 & $0.057-0.173$ & 0.113 & $-\quad \quad-$ \\
\hline 1998 & spring & 513 & 240 & 0.468 & $0.424-0.512$ & 0.548 & $0.487-0.622$ \\
\hline 1999 & fall & 500 & 130 & 0.260 & $0.222-0.301$ & 0.269 & $0.229-0.315$ \\
\hline 1999 & winter & 420 & 42 & 0.100 & $0.073-0.133$ & 0.117 & $0.082-0.182$ \\
\hline 1999 & spring & 535 & 270 & 0.505 & $0.461-0.548$ & 0.538 & $0.486-0.600$ \\
\hline 2000 & fall & 493 & 107 & 0.217 & $0.181-0.256$ & 0.341 & $0.260-0.476$ \\
\hline 2000 & winter & 500 & 56 & 0.112 & $0.086-0.143$ & 0.133 & $0.099-0.183$ \\
\hline 2000 & spring & 495 & 191 & 0.386 & $0.343-0.430$ & 0.560 & $0.472-0.680$ \\
\hline 2001 & spring & 6 & 5 & 0.833 & $0.359-0.996$ & - & $-\quad \quad-$ \\
\hline 2001 & spring & 4 & 3 & 0.750 & $0.194-0.994$ & - & - \\
\hline stin & & & & & & & \\
\hline 1993 & summer & 1,001 & 207 & 0.207 & $0.182-0.233$ & 0.250 & $0.214-0.296$ \\
\hline 1994 & summer & 725 & 123 & 0.170 & $0.143-0.199$ & 0.237 & $0.188-0.309$ \\
\hline 1995 & summer & 1,002 & 181 & 0.181 & $0.157-0.206$ & 0.215 & $0.183-0.255$ \\
\hline 1996 & summer & 978 & 155 & 0.158 & $0.136-0.183$ & 0.237 & $0.191-0.306$ \\
\hline 1997 & summer & 527 & 83 & 0.157 & $0.127-0.191$ & 0.213 & $0.160-0.310$ \\
\hline 1997 & fall & 519 & 135 & 0.260 & $0.223-0.300$ & 0.312 & $0.247-0.465$ \\
\hline 1997 & winter & 390 & 106 & 0.272 & $0.228-0.319$ & 0.445 & $0.334-0.650$ \\
\hline 1997 & spring & 476 & 246 & 0.517 & $0.471-0.563$ & 0.769 & $0.630-1.009$ \\
\hline
\end{tabular}


Appendix Table A-9. Continued.

\begin{tabular}{|c|c|c|c|c|c|c|c|}
\hline \multirow[b]{2}{*}{$\begin{array}{l}\text { Stream, } \\
\text { migratory year }\end{array}$} & \multirow[b]{2}{*}{ Tag group } & \multirow[b]{2}{*}{$\begin{array}{c}\text { Number } \\
\text { tagged }\end{array}$} & & \multicolumn{2}{|c|}{ Detection rate } & \multicolumn{2}{|c|}{ CJS survival probability } \\
\hline & & & $\begin{array}{l}\text { Number } \\
\text { detected }\end{array}$ & Rate & $95 \% \mathrm{CI}$ & Probability & $95 \% \mathrm{CI}$ \\
\hline
\end{tabular}

Lostine River:

$\begin{array}{llrrrrrr}1998 & \text { fall } & 500 & 193 & 0.386 & 0.343-0.430 & 0.448 & 0.391-0.514 \\ 1998 & \text { winter } & 504 & 156 & 0.310 & 0.269-0.352 & 0.349 & 0.301-0.403 \\ 1998 & \text { spring } & 466 & 328 & 0.704 & 0.660-0.745 & 0.784 & 0.728-0.845 \\ 1999 & \text { summer } & 506 & 87 & 0.172 & 0.140-0.208 & 0.180 & 0.145-0.234 \\ 1999 & \text { fall } & 501 & 167 & 0.333 & 0.292-0.377 & 0.422 & 0.349-0.538 \\ 1999 & \text { winter } & 491 & 139 & 0.283 & 0.244-0.325 & 0.305 & 0.259-0.363 \\ 1999 & \text { spring } & 600 & 363 & 0.605 & 0.565-0.644 & 0.744 & 0.664-0.857 \\ 2000 & \text { summer } & 509 & 76 & 0.149 & 0.119-0.183 & 0.212 & 0.159-0.294 \\ 2000 & \text { fall } & 514 & 137 & 0.267 & 0.229-0.307 & 0.317 & 0.267-0.380 \\ 2000 & \text { winter } & 511 & 114 & 0.223 & 0.188-0.262 & 0.397 & 0.296-0.576 \\ 2000 & \text { spring } & 355 & 159 & 0.448 & 0.395-0.501 & 0.660 & 0.546-0.823 \\ 2001 & \text { summer } & 489 & 101 & 0.207 & 0.172-0.245 & 0.210 & 0.175-0.248 \\ 2001 & \text { fall } & 498 & 164 & 0.329 & 0.288-0.373 & 0.335 & 0.294-0.378 \\ 2001 & \text { winter } & 499 & 138 & 0.277 & 0.238-0.318 & 0.284 & 0.245-0.326 \\ 2001 & \text { spring } & 450 & 301 & 0.669 & 0.623-0.712 & 0.695 & 0.648-0.741\end{array}$

Minam River:

$\begin{array}{llrrrlll}1993 & \text { summer } & 1,000 & 152 & 0.152 & 0.130-0.176 & 0.187 & 0.155-0.230 \\ 1994 & \text { summer } & 997 & 213 & 0.214 & 0.189-0.240 & 0.293 & 0.249-0.350 \\ 1995 & \text { summer } & 996 & 124 & 0.124 & 0.105-0.147 & 0.153 & 0.124-0.191 \\ 1996 & \text { summer } & 998 & 154 & 0.154 & 0.132-0.178 & 0.208 & 0.169-0.264 \\ 1997 & \text { summer } & 589 & 102 & 0.173 & 0.143-0.206 & 0.270 & 0.181-0.693 \\ 1998 & \text { summer } & 1,010 & 207 & 0.205 & 0.180-0.231 & 0.228 & 0.199-0.259 \\ 1999 & \text { summer } & 1,006 & 172 & 0.171 & 0.148-0.196 & 0.180 & 0.155-0.210 \\ 2000 & \text { summer } & 998 & 175 & 0.175 & 0.152-0.200 & 0.239 & 0.199-0.292 \\ 2001 & \text { summer } & 1,000 & 221 & 0.221 & 0.196-0.248 & 0.228 & 0.202-0.256 \\ 2001 & \text { fall } & 300 & 126 & 0.420 & 0.364-0.478 & 0.427 & 0.371-0.485 \\ 2001 & \text { spring } & 536 & 324 & 0.604 & 0.562-0.646 & 0.619 & 0.576-0.661\end{array}$

Imnaha River:

$\begin{array}{llrrrrrr}1993 & \text { summer } & 1,003 & 117 & 0.117 & 0.097-0.138 & 0.142 & 0.115-0.180 \\ 1994 & \text { summer } & 998 & 108 & 0.108 & 0.090-0.129 & 0.136 & 0.109-0.173 \\ 1995 & \text { summer } & 996 & 73 & 0.073 & 0.058-0.091 & 0.083 & 0.064-0.108 \\ 1996 & \text { summer } & 997 & 188 & 0.189 & 0.165-0.214 & 0.268 & 0.222-0.330 \\ 1997 & \text { summer } & 1,017 & 176 & 0.173 & 0.150-0.198 & 0.216 & 0.179-0.276 \\ 1998 & \text { summer } & 998 & 280 & 0.281 & 0.253-0.310 & 0.325 & 0.290-0.366 \\ 1999 & \text { summer } & 1,009 & 143 & 0.142 & 0.121-0.165 & 0.173 & 0.141-0.219 \\ 2000 & \text { summer } & 982 & 114 & 0.116 & 0.097-0.138 & 0.141 & 0.115-0.172 \\ 2001 & \text { summer } & 1,000 & 180 & 0.180 & 0.157-0.205 & 0.181 & 0.158-0.206\end{array}$


Appendix Table A-9. Continued.

\begin{tabular}{|c|c|c|c|c|c|c|c|}
\hline \multirow[b]{2}{*}{$\begin{array}{l}\text { Stream, } \\
\text { migratory year }\end{array}$} & \multirow[b]{2}{*}{ Tag group } & \multirow[b]{2}{*}{$\begin{array}{c}\text { Number } \\
\text { tagged }\end{array}$} & \multirow[b]{2}{*}{$\begin{array}{l}\text { Number } \\
\text { detected }\end{array}$} & \multicolumn{2}{|c|}{ Detection rate } & \multicolumn{2}{|c|}{ CJS survival probability } \\
\hline & & & & Rate & $95 \% \mathrm{CI}$ & Probability & $95 \% \mathrm{CI}$ \\
\hline
\end{tabular}

Wenaha and South Fork Wenaha rivers

\begin{tabular}{llrrrrrr}
1993 & summer & 751 & 142 & 0.189 & $0.162-0.219$ & 0.214 & $0.180-0.254$ \\
1994 & summer & 998 & 129 & 0.129 & $0.109-0.152$ & 0.144 & $0.121-0.172$ \\
1995 & summer & 999 & 120 & 0.120 & $0.101-0.142$ & 0.146 & $0.119-0.180$ \\
1996 & summer & 997 & 158 & 0.158 & $0.136-0.183$ & 0.212 & $0.172-0.271$ \\
1997 & summer & 62 & 16 & 0.258 & $0.155-0.385$ & - & - \\
\hline
\end{tabular}


Appendix Table A-10. Comparisons of overwinter survival of spring chinook salmon parr in rearing areas upstream (above screw trap) and downstream (below screw trap) on Catherine Creek and the Lostine and Grande Ronde rivers. Screw traps are located on Catherine Creek at rkm 32, Lostine River at rkm 3, and Grande Ronde River at rkm 299, except migratory year 1995 when the upper Grande Ronde River trap was at rkm 257. $P$-value is based on the maximum likelihood ratio test comparing the fit of the null model (fall tag group survival probability = winter tag group survival probability) to the fit of the full model (fall tag group survival probability $\neq$ winter tag group survival probability).

\begin{tabular}{|c|c|c|c|c|c|c|}
\hline $\begin{array}{c}\text { Migratory } \\
\text { year }\end{array}$ & \multicolumn{2}{|c|}{ Catherine Creek } & \multicolumn{2}{|c|}{ Lostine River } & \multicolumn{2}{|c|}{ Grande Ronde River } \\
\hline 1994 & - & - & - & - & Equivalent & 0.331 \\
\hline 1996 & Equivalent & 0.766 & - & - & - & - \\
\hline 1997 & Downstream & 0.016 & Equivalent & 0.133 & - & - \\
\hline 1998 & Equivalent & 0.289 & Downstream & 0.014 & Downstream & $<0.001$ \\
\hline 2001 & Downstream & 0.009 & Equivalent & 0.090 & - & - \\
\hline
\end{tabular}


Appendix Table A-11. Overwinter survival rates of spring chinook salmon parr overwintering upstream of screw traps on Catherine Creek and the Lostine and Grande Ronde rivers. Screw traps are located on Catherine Creek at rkm 32, Lostine River at rkm 3, and Grande Ronde River at rkm 299, except migratory year 1995 when the upper Grande Ronde River trap was at rkm 257. Survival rates were calculated by dividing the CJS survival probability of the winter tag group by the CJS survival probability of the spring tag group.

\begin{tabular}{lcccc}
\hline Migratory & \multirow{2}{*}{$\begin{array}{c}\text { Brood } \\
\text { year }\end{array}$} & \multicolumn{3}{c}{ Overwinter survival in upper rearing areas } \\
\cline { 3 - 5 } & year & Catherine Creek & Lostine River & Upper Grande Ronde River \\
\hline 1994 & 1992 & - & - & 0.54 \\
1995 & 1993 & 0.55 & - & 0.25 \\
1996 & 1994 & 0.53 & - & - \\
1997 & 1995 & 0.19 & 0.58 & - \\
1998 & 1996 & 0.54 & 0.45 & 0.21 \\
1999 & 1997 & 0.64 & 0.41 & 0.22 \\
2000 & 1998 & 0.31 & 0.60 & 0.24 \\
2001 & 1999 & 0.20 & 0.41 & - \\
\hline
\end{tabular}


Appendix Table A-12. Median, first, and last migration dates to Lower Granite Dam for spring chinook salmon smolts PIT-tagged as parr during the previous summer, 19932001 migratory years. Migration date is date of detection at Lower Granite Dam. DOY $=$ day of year.

\begin{tabular}{|c|c|c|c|c|c|c|c|}
\hline \multirow[b]{2}{*}{ Stream, migratory year } & \multirow{2}{*}{$\begin{array}{l}\text { Number } \\
\text { detected }\end{array}$} & \multicolumn{2}{|c|}{ Median } & \multicolumn{2}{|c|}{ First } & \multicolumn{2}{|c|}{ Last } \\
\hline & & Date & DOY & Date & DOY & Date & DOY \\
\hline
\end{tabular}

Catherine Creek:

$\begin{array}{lrrrrrrr}1993 & 125 & 05 / 18 & 138 & 04 / 29 & 119 & 06 / 26 & 177 \\ 1994 & 91 & 05 / 11 & 131 & 04 / 13 & 103 & 07 / 26 & 207 \\ 1995 & 88 & 05 / 25 & 145 & 04 / 26 & 116 & 07 / 02 & 183 \\ 1996 & 60 & 05 / 01 & 122 & 04 / 17 & 108 & 05 / 29 & 150 \\ 1997 & 51 & 05 / 14 & 134 & 04 / 24 & 114 & 06 / 10 & 161 \\ 1998 & 43 & 05 / 17 & 137 & 04 / 24 & 114 & 06 / 04 & 155 \\ 1999 & 20 & 05 / 26 & 146 & 04 / 26 & 116 & 06 / 26 & 177 \\ 2000 & 30 & 05 / 07 & 128 & 04 / 12 & 103 & 06 / 07 & 159 \\ 2001 & 33 & 05 / 17 & 137 & 04 / 28 & 118 & 07 / 03 & 184\end{array}$

Upper Grande Ronde River:

$\begin{array}{lrrrrrrr}1993 & 117 & 05 / 17 & 137 & 04 / 23 & 113 & 06 / 20 & 171 \\ 1994 & 57 & 05 / 29 & 149 & 04 / 23 & 113 & 08 / 29 & 241 \\ 1995 & 89 & 05 / 29 & 149 & 04 / 12 & 102 & 07 / 01 & 182\end{array}$

Lostine River:

$\begin{array}{lrrrcccc}1993 & 136 & 05 / 04 & 124 & 04 / 17 & 107 & 06 / 01 & 152 \\ 1994 & 77 & 05 / 02 & 122 & 04 / 19 & 109 & 06 / 07 & 158 \\ 1995 & 115 & 05 / 02 & 122 & 04 / 08 & 98 & 06 / 09 & 160 \\ 1996 & 129 & 05 / 15 & 136 & 04 / 17 & 108 & 06 / 19 & 171 \\ 1997 & 43 & 04 / 25 & 115 & 04 / 09 & 99 & 05 / 21 & 141 \\ 1999 & 19 & 05 / 15 & 135 & 03 / 29 & 88 & 05 / 29 & 149 \\ 2000 & 36 & 05 / 08 & 129 & 04 / 13 & 104 & 06 / 03 & 155 \\ 2001 & 87 & 05 / 09 & 129 & 04 / 10 & 100 & 06 / 12 & 163 \\ & & & & & & & \\ \text { ha River: } & & & & & & & \\ 1993 & 74 & 05 / 14 & 134 & 04 / 15 & 105 & 06 / 23 & 174 \\ 1994 & 65 & 05 / 08 & 128 & 04 / 20 & 110 & 08 / 11 & 223 \\ 1995 & 41 & 05 / 02 & 122 & 04 / 10 & 100 & 070 / 7 & 188 \\ 1996 & 158 & 04 / 26 & 117 & 04 / 14 & 105 & 06 / 12 & 164 \\ 1997 & 98 & 04 / 19 & 109 & 03 / 31 & 90 & 06 / 02 & 153 \\ 1998 & 159 & 04 / 29 & 119 & 04 / 03 & 93 & 05 / 24 & 144 \\ 1999 & 41 & 05 / 08 & 128 & 04 / 17 & 107 & 06 / 03 & 154 \\ 2000 & 63 & 05 / 02 & 123 & 04 / 12 & 103 & 06 / 16 & 168 \\ 2001 & 159 & 04 / 30 & 120 & 04 / 08 & 98 & 05 / 28 & 148\end{array}$


Appendix Table A-12. Continued.

\begin{tabular}{|c|c|c|c|c|c|c|c|}
\hline \multirow[b]{2}{*}{ Stream, migratory year } & \multirow{2}{*}{$\begin{array}{l}\text { Number } \\
\text { detected }\end{array}$} & \multicolumn{2}{|c|}{ Median } & \multicolumn{2}{|c|}{ First } & \multicolumn{2}{|c|}{ Last } \\
\hline & & date & DOY & date & DOY & date & DOY \\
\hline \multicolumn{8}{|l|}{ Minam River: } \\
\hline 1993 & 113 & 05/04 & 124 & $04 / 18$ & 108 & $06 / 03$ & 154 \\
\hline 1994 & 120 & $04 / 29$ & 119 & $04 / 18$ & 108 & $08 / 13$ & 225 \\
\hline 1995 & 71 & $05 / 02$ & 122 & $04 / 08$ & 98 & $06 / 07$ & 158 \\
\hline 1996 & 117 & $04 / 24$ & 115 & $04 / 10$ & 101 & $06 / 07$ & 159 \\
\hline 1997 & 49 & $04 / 16$ & 106 & $04 / 03$ & 93 & $05 / 13$ & 133 \\
\hline 1998 & 123 & $04 / 29$ & 119 & $04 / 03$ & 93 & $05 / 30$ & 150 \\
\hline 1999 & 50 & $04 / 29$ & 119 & $03 / 31$ & 90 & $06 / 02$ & 153 \\
\hline 2000 & 74 & $05 / 03$ & 124 & $04 / 10$ & 101 & $05 / 29$ & 150 \\
\hline 2001 & 178 & $05 / 08$ & 128 & $04 / 08$ & 98 & $06 / 12$ & 163 \\
\hline
\end{tabular}

Wenaha and South Fork Wenaha rivers:

1993

1994

1995

1996

1997
84

93

76

105

10 $\begin{array}{llllll}04 / 28 & 118 & 04 / 14 & 104 & 05 / 15 & 135\end{array}$

$\begin{array}{llllll}04 / 24 & 114 & 04 / 18 & 108 & 06 / 06 & 157\end{array}$

$\begin{array}{llllll}04 / 26 & 116 & 04 / 09 & 99 & 05 / 15 & 135\end{array}$

$\begin{array}{llllll}04 / 21 & 112 & 04 / 13 & 104 & 05 / 16 & 137\end{array}$

$\begin{array}{llllll}04 / 16 & 106 & 04 / 09 & 99 & 04 / 23 & 113\end{array}$





\section{APPENDIX B}

A Compilation of Oncorhynchus mykiss Data 
Appendix Table B-1. Population estimates of wild O. mykiss in Catherine Creek and its tributaries above the screw trap (rkm 32) during summer.

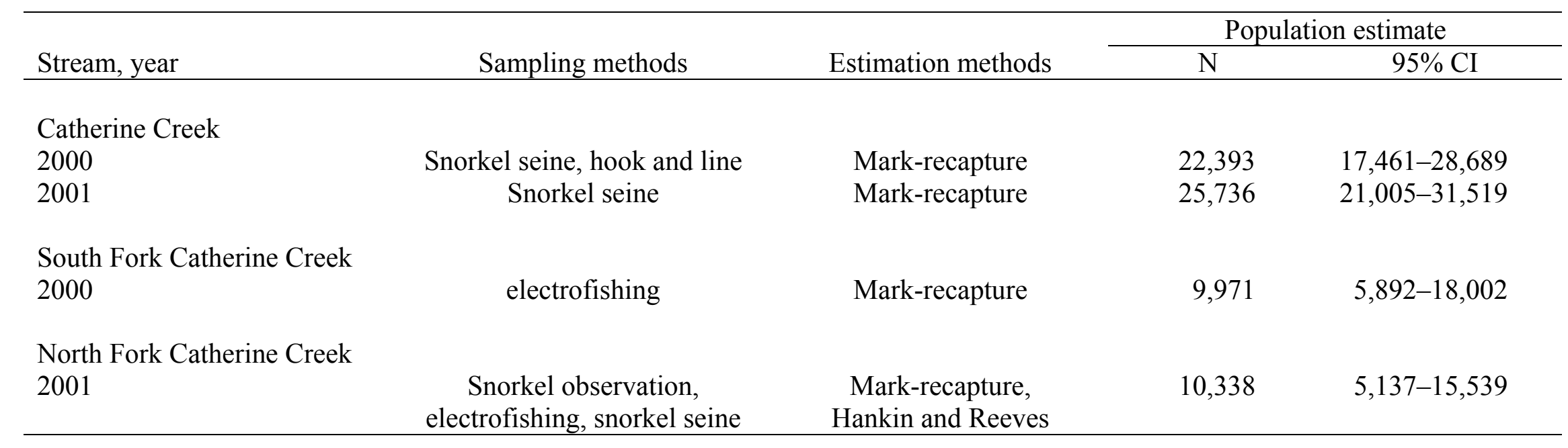


Appendix Table B-2. Age composition of O. mykiss sampled in Catherine Creek and two tributaries in summer 2000 and 2001. Age was determined by scale analysis.

\begin{tabular}{lccccc}
\hline Stream, year sampled & Age & $\mathrm{N}^{\mathrm{a}}$ & $\begin{array}{c}\text { Length range } \\
(\mathrm{FL}, \mathrm{mm})\end{array}$ & $\begin{array}{c}\text { Percent of } \\
\text { population }\end{array}$ & $95 \% \mathrm{CI}$ \\
\hline \multirow{2}{*}{$\begin{array}{l}\text { Catherine Creek } \\
2000\end{array}$} & & & & & \\
& 0 & 4 & $65-72$ & 2.6 & $1.2-7.0$ \\
& 1 & 92 & $69-160$ & 59.9 & $52.1-67.6$ \\
& 2 & 46 & $113-218$ & 29.9 & $23.2-37.7$ \\
& 3 & 12 & $163-263$ & 7.8 & $4.6-13.5$ \\
& & & & & \\
& 0 & 0 & & $(\mathrm{~b})$ & \\
& 1 & 196 & $72-163$ & 86.7 & $81.6-90.7$ \\
& 2 & 29 & $114-200$ & 12.8 & $8.8-17.9$ \\
& 3 & 1 & 221 & 0.4 & $0.0-2.4$
\end{tabular}

South Fork Catherine Creek 2000

$\begin{array}{rrrrr}0 & 3 & 59-69 & 6.1 & 1.7-16.7 \\ 1 & 35 & 86-167 & 71.4 & 57.0-82.3 \\ 2 & 7 & 123-177 & 14.3 & 6.7-26.8 \\ 3 & 4 & 159-198 & 8.1 & 2.8-18.8\end{array}$

North Fork Catherine Creek 2001

\begin{tabular}{rrrrr}
0 & 8 & $52-98$ & $17.3^{\mathrm{c}}$ & - \\
1 & 106 & $70-159$ & $55.9^{\mathrm{c}}$ & - \\
2 & 52 & $118-213$ & $24.4^{\mathrm{c}}$ & - \\
3 & 6 & $178-215$ & $2.5^{\mathrm{c}}$ & - \\
\hline
\end{tabular}

a Number of fish for which age was determined.

$\mathrm{b}$ The fork lengths of 13 of the 1,024 (1.3\%) O. mykiss measured on Catherine Creek were less than $72 \mathrm{~mm}$. It is likely that some of these fish are age-0.

c Percentage of population in each age class calculated using an age-length key. 
Appendix Table B-3. Travel time to Lower Granite Dam of wild O. mykiss PIT-tagged at screw traps in spring and detected at the dam in the same migratory year. Bold mean indicates normal distribution of travel times. Bold median indicates non-normal distribution.

\begin{tabular}{lccccc}
\hline \multirow{2}{*}{ Stream } & Migratory & Number & \multicolumn{3}{c}{ Travel time (days) } \\
year & detected & Mean & Median & Range \\
\hline Upper Grande Ronde River & 2000 & 73 & $\mathbf{3 3 . 0}$ & 31.2 & $6-78$ \\
& 2001 & 180 & 36.7 & $\mathbf{3 7 . 3}$ & $8-152$ \\
Catherine Creek & & & & & \\
& 2000 & 63 & 27.6 & $\mathbf{2 6 . 6}$ & $7-91$ \\
Lostine River & 2001 & 88 & 33.0 & $\mathbf{3 3 . 2}$ & $7-74$ \\
& 2000 & 166 & 17.2 & $\mathbf{1 1 . 7}$ & $4-66$ \\
Minam River & 2001 & 164 & 17.6 & $\mathbf{1 3 . 9}$ & $5-109$ \\
& 2001 & 240 & 21.8 & $\mathbf{1 6 . 6}$ & $5-110$ \\
\hline
\end{tabular}


Appendix Table B-4. Detections dates at Lower Granite Dam of wild O. mykiss PIT-tagged at screw traps as early and late migrants. Numbers of fish detected were expanded for spillway flow. Median detection dates that have a letter in common are not significantly different (MannWhitney rank sum test, $P<0.05)$. Parentheses indicate that correlation between the number tagged and the number migrating past the trap during spring was not determined and the median might be biased. * indicates no correlation between the number tagged and the number migrating, so median was biased.

\begin{tabular}{|c|c|c|c|c|c|c|}
\hline \multirow{2}{*}{$\begin{array}{l}\text { Stream, } \\
\text { migratory year }\end{array}$} & \multirow{2}{*}{$\begin{array}{c}\text { Season of } \\
\text { tagging }\end{array}$} & \multirow{2}{*}{$\begin{array}{c}\text { Number } \\
\text { tagged }\end{array}$} & \multirow{2}{*}{$\begin{array}{l}\text { Number } \\
\text { detected }\end{array}$} & \multicolumn{3}{|c|}{ Detection dates } \\
\hline & & & & Median & First & Last \\
\hline \multicolumn{7}{|c|}{ Upper Grande Ronde River } \\
\hline \multirow[t]{2}{*}{2000} & Fall & 110 & 7 & $04 / 30$ & $04 / 18$ & $05 / 26$ \\
\hline & Spring & 462 & 73 & $(05 / 07)$ & $03 / 31$ & $06 / 28$ \\
\hline \multirow[t]{2}{*}{2001} & Fall & 61 & 10 & $05 / 07$ & $04 / 28$ & $06 / 29$ \\
\hline & Spring & 475 & 180 & $05 / 05^{*}$ & $04 / 26$ & $08 / 28$ \\
\hline \multicolumn{7}{|l|}{ Catherine Creek } \\
\hline \multirow[t]{2}{*}{2000} & Fall & 989 & 43 & $04 / 20$ & $04 / 02$ & $06 / 29$ \\
\hline & Spring & 502 & 63 & $(05 / 06)$ & 04/06 & $06 / 10$ \\
\hline \multirow[t]{2}{*}{2001} & Fall & 561 & 66 & $05 / 06 \mathrm{a}$ & $04 / 18$ & $06 / 12$ \\
\hline & Spring & 266 & 88 & $05 / 14 \mathrm{a}$ & $04 / 22$ & $06 / 11$ \\
\hline \multicolumn{7}{|l|}{ Lostine River } \\
\hline \multirow[t]{2}{*}{2000} & Fall & 777 & 116 & $05 / 10$ & $03 / 26$ & $06 / 16$ \\
\hline & Spring & 532 & 166 & $(05 / 06)$ & $04 / 13$ & $06 / 13$ \\
\hline \multirow[t]{2}{*}{2001} & Fall & 421 & 13 & $05 / 12 b$ & $04 / 16$ & $06 / 13$ \\
\hline & Spring & 345 & 164 & $05 / 14 b$ & $04 / 13$ & $08 / 18$ \\
\hline \multicolumn{7}{|l|}{ Minam River } \\
\hline 2001 & Fall & 32 & 6 & $05 / 09 \mathrm{c}$ & $05 / 02$ & $05 / 17$ \\
\hline & Spring & 454 & 240 & $05 / 07 \mathrm{c}$ & $04 / 26$ & $08 / 29$ \\
\hline
\end{tabular}


Appendix Table B-5. Detections dates at Lower Granite Dam of wild O. mykiss that were PITtagged in the upper rearing areas of the Catherine Creek during summer 2000 and detected in 2001. Numbers of fish detected were expanded for spillway flow.

\begin{tabular}{|c|c|c|c|c|c|}
\hline \multirow[b]{2}{*}{ Stream } & \multirow{2}{*}{$\begin{array}{c}\text { Number } \\
\text { tagged }\end{array}$} & \multirow{2}{*}{$\begin{array}{l}\text { Number } \\
\text { detected }\end{array}$} & \multicolumn{3}{|c|}{ Detection dates } \\
\hline & & & Median & First & Last \\
\hline Catherine Creek & 412 & 19 & $05 / 08$ & $04 / 25$ & $06 / 25$ \\
\hline North Fork Catherine Creek & 117 & 2 & 05/07 & $05 / 01$ & $05 / 12$ \\
\hline South Fork Catherine Creek & 225 & 5 & $05 / 06$ & $05 / 02$ & $05 / 14$ \\
\hline Little Catherine Creek & 415 & 0 & - & - & - \\
\hline Total & 1,169 & 26 & $05 / 08$ & $04 / 25$ & $06 / 25$ \\
\hline
\end{tabular}

Appendix Table B-6. Detection dates at Lower Granite Dam of wild O. mykiss PIT-tagged at screw traps during fall and spring in migratory year 2000 and detected at the dam in migratory year 2001.

\begin{tabular}{lcccc}
\hline & Number & \multicolumn{3}{c}{ Detection dates } \\
\cline { 3 - 5 } Stream & detected & Median & First & Last \\
\hline & & & & \\
Upper Grande Ronde River & 7 & $05 / 03$ & $04 / 30$ & $06 / 06$ \\
Catherine Creek & 25 & $05 / 04$ & $04 / 02$ & $05 / 26$ \\
Lostine River & 22 & $05 / 04$ & $04 / 27$ & $06 / 07$ \\
\hline
\end{tabular}


Appendix Table B-7. Detection rates at Snake and Columbia River dams of wild O. mykiss PIT-tagged at screw traps during spring and fall. $\mathrm{MY}=$ Migratory year.

\begin{tabular}{|c|c|c|c|c|c|c|c|c|c|c|c|}
\hline \multirow{2}{*}{$\begin{array}{l}\text { Stream, year and } \\
\text { season of tagging }\end{array}$} & \multirow[b]{2}{*}{ MY } & \multirow{2}{*}{$\begin{array}{c}\text { Number } \\
\text { tagged }\end{array}$} & \multicolumn{3}{|c|}{ Detections during MY } & \multicolumn{3}{|c|}{ Detections during MY+1 } & \multicolumn{3}{|c|}{ All detections } \\
\hline & & & Number & Rate & $95 \% \mathrm{CI}$ & Number & Rate & $95 \% \mathrm{CI}$ & Number & Rate & $95 \% \mathrm{CI}$ \\
\hline \multicolumn{12}{|c|}{ Upper Grande Ronde River } \\
\hline $1999 \quad$ Fall & 2000 & 110 & 16 & 0.145 & $0.085-0.225$ & 0 & 0.000 & $0.000-0.033$ & 16 & 0.145 & $0.085-0.225$ \\
\hline 2000 Spring $^{\mathrm{a}}$ & 2000 & 324 & 99 & 0.306 & $0.256-0.359$ & 1 & 0.003 & $0.000-0.017$ & 100 & 0.309 & $0.259-0.362$ \\
\hline Spring & 2000 & 126 & 0 & 0.000 & $0.000-0.029$ & 5 & 0.040 & $0.013-0.090$ & 5 & 0.040 & $0.013-0.090$ \\
\hline Fall & 2001 & 61 & 12 & 0.197 & $0.106-0.318$ & - & - & - & 12 & 0.197 & $0.106-0.318$ \\
\hline Spring $^{\mathrm{a}}$ & 2001 & 465 & 196 & 0.422 & $0.376-0.468$ & - & - & - & 196 & 0.422 & $0.376-0.468$ \\
\hline Spring $^{b}$ & 2001 & 7 & 0 & 0.000 & $0.000-0.410$ & - & - & - & 0 & 0.000 & $0.000-0.410$ \\
\hline \multicolumn{12}{|l|}{ Catherine Creek } \\
\hline $1999 \quad$ Fall & 2000 & 989 & 73 & 0.074 & 0.058-0.092 & 14 & 0.014 & $0.008-0.024$ & 87 & 0.088 & $0.071-0.107$ \\
\hline 2000 Spring $^{\mathrm{a}}$ & 2000 & 305 & 103 & 0.338 & $0.285-0.394$ & 2 & 0.007 & $0.001-0.023$ & 105 & 0.344 & $0.391-0.401$ \\
\hline Spring ${ }^{b}$ & 2000 & 186 & 0 & 0.000 & $0.000-0.020$ & 10 & 0.054 & $0.026-0.097$ & 10 & 0.054 & $0.026-0.097$ \\
\hline \multirow[b]{2}{*}{2001} & 2001 & 561 & 67 & 0.119 & $0.094-0.149$ & - & - & - & 67 & 0.119 & 0.094-0.149 \\
\hline & 2001 & 247 & 96 & 0.389 & $0.328-0.453$ & - & - & - & 96 & 0.389 & $0.328-0.453$ \\
\hline Spring $^{b}$ & 2001 & 19 & 1 & 0.053 & $0.001-0.260$ & - & - & - & 1 & 0.053 & $0.001-0.260$ \\
\hline \multicolumn{12}{|l|}{ Lostine River } \\
\hline $1999 \quad$ Fall & 2000 & 777 & 157 & 0.202 & $0.174-0.232$ & 11 & 0.014 & $0.007-0.025$ & 168 & 0.216 & $0.188-0.247$ \\
\hline \multirow[t]{2}{*}{2000} & 2000 & 442 & 234 & 0.529 & $0.482-0.577$ & 4 & 0.009 & $0.002-0.023$ & 238 & 0.538 & $0.491-0.586$ \\
\hline & 2000 & 82 & 0 & 0.000 & $0.000-0.044$ & 9 & 0.110 & $0.051-0.198$ & 9 & 0.110 & $0.051-0.198$ \\
\hline \multirow{3}{*}{2001} & 2001 & 421 & 17 & 0.040 & $0.024-0.064$ & - & - & - & 17 & 0.040 & $0.024-0.064$ \\
\hline & 2001 & 323 & 182 & 0.563 & $0.507-0.618$ & - & - & - & 182 & 0.563 & $0.507-0.618$ \\
\hline & 2001 & 21 & 1 & 0.048 & $0.001-0.238$ & - & - & - & 1 & 0.048 & $0.001-0.238$ \\
\hline \multicolumn{12}{|l|}{ Minam River } \\
\hline $2000 \quad$ Fall & 2001 & 32 & 7 & 0.219 & $0.093-0.400$ & - & - & - & 7 & 0.219 & $0.093-0.400$ \\
\hline 2001 Spring $^{\mathrm{a}}$ & 2001 & 442 & 269 & 0.609 & $0.561-0.654$ & - & - & - & 269 & 0.609 & $0.561-0.654$ \\
\hline Spring & 2001 & 12 & 2 & 0.167 & $0.021-0.484$ & - & - & - & 2 & 0.167 & $0.021-0.484$ \\
\hline
\end{tabular}

a Only O. mykiss $\geq 115 \mathrm{~mm}$ FL at time of tagging.

b Only O. mykiss $<115 \mathrm{~mm}$ FL at time of tagging. 
Appendix Table B-8. Fork lengths of $O$. mykiss PIT-tagged at screw traps on Catherine Creek and the upper Grande Ronde, Lostine, and Minam rivers in the fall (early migrants), summarized by dam detection history. Bold type indicates whether lengths are normally distributed (Kolmogorov-Smirnov, P > 0.05), in which case mean is bold, or not normally distributed (median is bold).

\begin{tabular}{|c|c|c|c|c|c|c|c|c|c|}
\hline \multirow{3}{*}{$\begin{array}{l}\text { Stream, } \\
\text { migratory year tagged }\end{array}$} & \multirow{3}{*}{$\begin{array}{c}\text { Migratory } \\
\text { year } \\
\text { detected }\end{array}$} & \multirow[b]{3}{*}{$\mathrm{N}$} & \multicolumn{7}{|c|}{ Length at tagging (mm) } \\
\hline & & & \multirow[b]{2}{*}{ Median } & \multirow[b]{2}{*}{ Mean } & \multirow[b]{2}{*}{$95 \% \mathrm{CI}$} & \multicolumn{2}{|c|}{ Percentile } & \multirow[b]{2}{*}{ Minimum } & \multirow[b]{2}{*}{ Maximum } \\
\hline & & & & & & $25^{\text {th }}$ & $75^{\text {th }}$ & & \\
\hline \multicolumn{10}{|c|}{ Upper Grande Ronde River } \\
\hline 2000 & (a) & 108 & 132.5 & 133.7 & \pm 4.9 & 121.5 & 148 & 71 & 205 \\
\hline \multirow[t]{2}{*}{2001} & (a) & 60 & 124 & 125.5 & \pm 6.7 & 100.5 & 144.5 & 86 & 180 \\
\hline & 2001 & 12 & 152 & 148.3 & \pm 12.7 & 133.5 & 160.5 & 115 & 180 \\
\hline \multicolumn{10}{|l|}{ Catherine Creek } \\
\hline \multirow[t]{3}{*}{2000} & (a) & 986 & 101 & 110.6 & \pm 2.3 & 76 & 142 & 60 & 200 \\
\hline & 2000 & 73 & 148 & 148.5 & \pm 5.7 & 132.8 & 162 & 67 & 195 \\
\hline & 2001 & 14 & 77 & 80.2 & \pm 7.6 & 73 & 86 & 61 & 118 \\
\hline \multirow[t]{2}{*}{2001} & (a) & 561 & 136 & 137.7 & \pm 1.8 & 124 & 150.3 & 76 & 204 \\
\hline & 2001 & 67 & 139 & 141.9 & \pm 5.4 & 126.3 & 151.8 & 102 & 195 \\
\hline \multicolumn{10}{|l|}{ Lostine River } \\
\hline \multirow[t]{3}{*}{2000} & (a) & 773 & 153 & 154.5 & \pm 1.9 & 140 & 168 & 66 & 286 \\
\hline & 2000 & 157 & 157 & 159.3 & \pm 3.3 & 144 & 170 & 121 & 259 \\
\hline & 2001 & 11 & 105 & 105 & \pm 14.0 & 85 & 119 & 79 & 141 \\
\hline \multirow[t]{2}{*}{2001} & (a) & 421 & 80 & 90.5 & \pm 2.9 & 73 & 91 & 61 & 235 \\
\hline & 2001 & 17 & 161 & 157.6 & \pm 18.2 & 145.8 & 177.5 & 95 & 212 \\
\hline \multicolumn{10}{|l|}{ Minam River } \\
\hline 2001 & (a) & 32 & 121.5 & 116.1 & \pm 17.3 & 69 & 152.5 & 58 & 218 \\
\hline & 2001 & 7 & 147 & 143.1 & \pm 21.3 & 126 & 154.5 & 114 & 183 \\
\hline
\end{tabular}

${ }^{a}$ Data represents entire tag group, regardless of detection history. 
Appendix Table B-9. Fork lengths of O. mykiss PIT-tagged at upper screw traps on Catherine Creek and the upper Grande Ronde, Lostine, and Minam rivers in the spring (late migrants), summarized by dam detection history. 'NA' in Detection Year indicates data for whole tag group. Bold type indicates whether lengths are normally distributed (Kolmogorov-Smirnov, P $>0.05$ ), in which case mean is bold, or not normally distributed (median is bold).

\begin{tabular}{|c|c|c|c|c|c|c|c|c|c|}
\hline \multirow{3}{*}{$\begin{array}{l}\text { Stream, } \\
\text { migratory year tagged }\end{array}$} & \multirow{3}{*}{$\begin{array}{c}\text { Migratory } \\
\text { year } \\
\text { detected }\end{array}$} & \multirow[b]{3}{*}{$\mathrm{N}$} & \multicolumn{7}{|c|}{ Length at tagging $(\mathrm{mm})$} \\
\hline & & & & & & & & & \\
\hline & & & Median & Mean & $95 \% \mathrm{CI}$ & $25^{\text {th }}$ & $75^{\text {th }}$ & Minimum & Maximum \\
\hline
\end{tabular}

Upper Grande Ronde River 2000

(a) 453

$\begin{array}{rr}\mathbf{1 3 3} & 130.6 \\ 155 & \mathbf{1 5 4 . 0} \\ \mathbf{8 0} & 90.7 \\ \mathbf{1 4 6} & 149.4 \\ \mathbf{1 5 6} & 158.2\end{array}$

2.7
3.7
22.7
1.9
2.7

107.8
139.3
77
134
145

152
166
109
162.5
171

71
115
72
81
115

(a) $\quad 472$

158.2

2.7

Е Catherine Creek

2000

2001

$\begin{array}{crr}\text { (a) } & 494 & \mathbf{1 3 1 . 5} \\ 2000 & 103 & \mathbf{1 5 2} \\ 2001 & 12 & 78.5 \\ \text { (a) } & 266 & 141 \\ 2001 & 97 & 150\end{array}$

122.8
154.8
$\mathbf{8 8 . 1}$
$\mathbf{1 4 0 . 0}$
$\mathbf{1 4 9 . 7}$

$\begin{array}{rr}3.1 & 86 \\ 3.6 & 143 \\ 12.6 & 73 \\ 2.5 & 127 \\ 3.6 & 137.8\end{array}$

$\begin{array}{rr}150 & 61 \\ 166.8 & 120 \\ 103.5 & 70 \\ 153 & 77 \\ 161 & 114\end{array}$

$$
\begin{aligned}
& 210 \\
& 210
\end{aligned}
$$$$
125
$$$$
190
$$$$
190
$$

Lostine River 2000

$\begin{array}{cr}\text { (a) } & 526 \\ 2000 & 234 \\ 2001 & 13 \\ (\mathrm{a}) & 344 \\ 2001 & 183\end{array}$

$\begin{array}{rr}\mathbf{1 6 0} & 155.0 \\ \mathbf{1 6 8} & 170.1 \\ \mathbf{8 9} & 100.6 \\ 160 & \mathbf{1 6 1 . 0} \\ 171 & \mathbf{1 7 2 . 9}\end{array}$

3.1
2.4
18.0
3.0
3.2

$\begin{array}{rrr}145 & 175 & 66 \\ 157 & 179 & 123 \\ 79.5 & 127.5 & 66 \\ 144 & 179 & 84 \\ 157 & 185 & 104\end{array}$

a Data represents entire tag group, regardless of detection history. 
Appendix Table B-9. Continued.

\begin{tabular}{|c|c|c|c|c|c|c|c|c|c|}
\hline \multirow{3}{*}{$\begin{array}{l}\text { Stream, } \\
\text { migratory year tagged }\end{array}$} & \multirow{3}{*}{$\begin{array}{c}\text { Migratory } \\
\text { year } \\
\text { detected }\end{array}$} & \multirow[b]{3}{*}{$\mathrm{N}$} & \multicolumn{7}{|c|}{ Length at tagging $(\mathrm{mm})$} \\
\hline & & & \multirow[b]{2}{*}{ Median } & \multirow[b]{2}{*}{ Mean } & \multirow[b]{2}{*}{$95 \% \mathrm{CI}$} & \multicolumn{2}{|c|}{ Percentile } & \multirow[b]{2}{*}{ Minimum } & \multirow[b]{2}{*}{ Maximum } \\
\hline & & & & & & $25^{\text {th }}$ & $75^{\text {th }}$ & & \\
\hline \multicolumn{10}{|l|}{ Minam River } \\
\hline 2001 & (a) & 454 & 159 & 159.7 & 2.2 & 143 & 177 & 78 & 227 \\
\hline & 2001 & 271 & 167 & 166.9 & 2.5 & 150.3 & 183 & 78 & 227 \\
\hline
\end{tabular}

Appendix Table B-10. Fork lengths of O. mykiss PIT-tagged upstream of the screw trap on Catherine Creek and its tributaries during summer 2000, summarized by migration history. Bold type indicates whether lengths are normally distributed (Kolmogorov-Smirnov, $\mathrm{P}>0.05$ ), in which case mean is bold, or not normally distributed (median is bold).

\begin{tabular}{|c|c|c|c|c|c|c|c|c|}
\hline \multirow[b]{3}{*}{ Group or migration history } & \multirow[b]{3}{*}{$\mathrm{N}$} & \multicolumn{7}{|c|}{ Length at tagging $(\mathrm{mm})$} \\
\hline & & \multirow[b]{2}{*}{ Median } & \multirow[b]{2}{*}{ Mean } & \multirow[b]{2}{*}{$95 \% \mathrm{CI}$} & \multicolumn{2}{|c|}{ Percentiles } & \multirow[b]{2}{*}{ Minimum } & \multirow[b]{2}{*}{ Maximum } \\
\hline & & & & & $25^{\text {th }}$ & $75^{\text {th }}$ & & \\
\hline All PIT-tagged & 1,163 & 113 & 116.5 & \pm 1.9 & 90.0 & 136.8 & 59 & 263 \\
\hline Fall 2000 trap recaptures & 21 & 124 & 121.5 & \pm 8.5 & 111.8 & 135.8 & 83 & 152 \\
\hline Spring 2001 trap recaptures & 5 & 125 & 121.4 & \pm 27.7 & 106.0 & 140.5 & 88 & 142 \\
\hline Migrated past trap before summer 2001 & 51 & 127 & 125.2 & \pm 5.7 & 113.0 & 138.8 & 83 & 170 \\
\hline Still upstream after spring 2001 & 12 & 92 & 95.8 & \pm 13.0 & 83.5 & 106.0 & 63 & 136 \\
\hline Detected at dams during 2001 & 29 & 130 & 128.9 & \pm 8.0 & 113.8 & 142.5 & 85 & 170 \\
\hline
\end{tabular}


